B O N N E V I L L E

Chinook Salmon Adult Abundance Monitoring in Lake Creek, Idaho

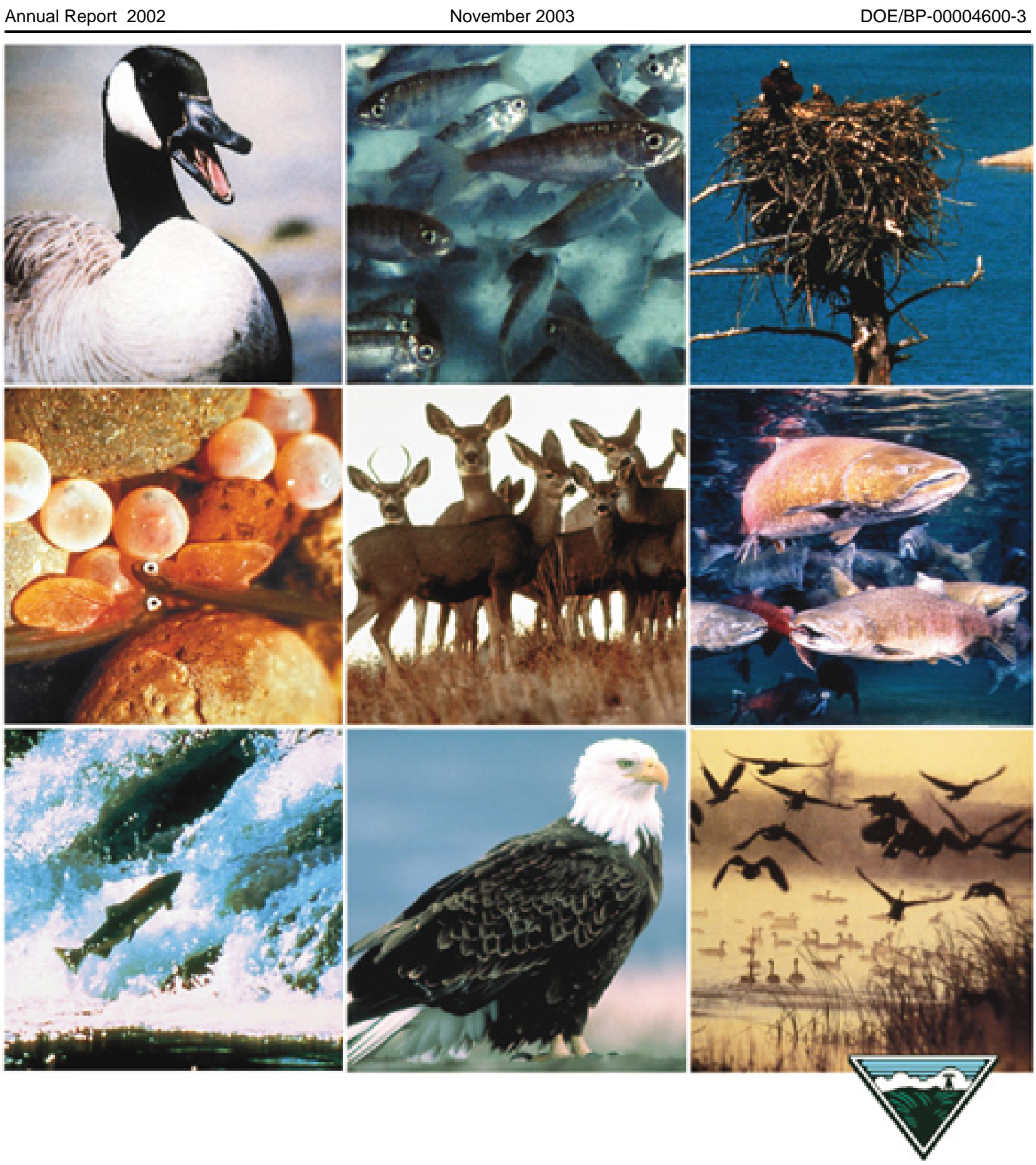


This Document should be cited as follows:

Faurot, Dave, Paul Kucera, "Chinook Salmon Adult Abundance Monitoring in Lake Creek, Idaho", 2002 Annual Report, Project No. 199703000, 96 electronic pages, (BPA Report DOE/BP -00004600-3)

\section{Bonneville Power Administration}

P.O. Box 3621

Portland, OR 97208

This report was funded by the Bonneville Power Administration (BPA), U.S. Department of Energy, as part of BPA's program to protect, mitigate, and enhance fish and wildlife affected by the development and operation of hydroelectric facilities on the Columbia River and its tributaries. The views in this report are the author's and do not necessarily represent the views of BPA. 


\section{Chinook Salmon Adult Abundance Monitoring in Lake Creek, Idaho, 2002}

2002 Annual Report

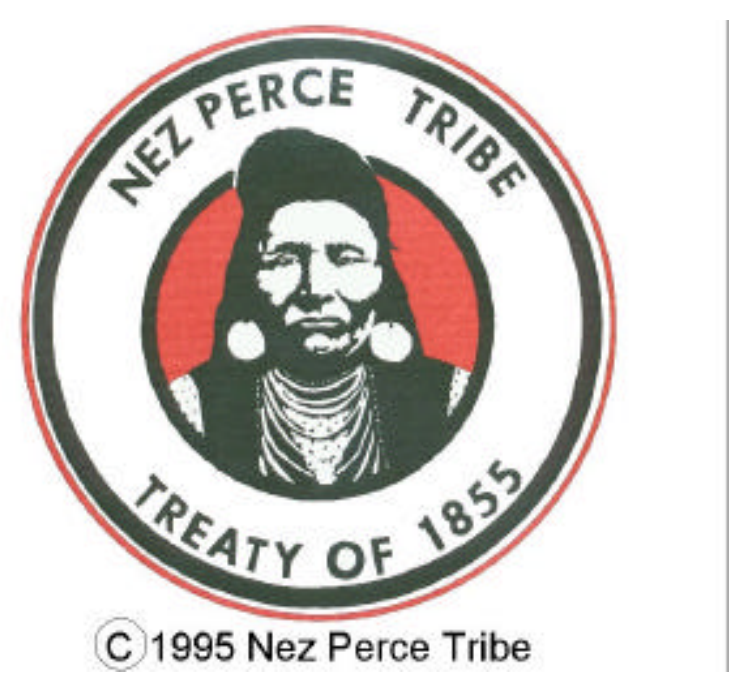

Prepared by:

Dave Faurot and Paul A. Kucera

Nez Perce Tribe

Department of Fisheries Resources Management

Lapwai, ID 83540

Prepared for:

U.S. Department of Energy

Bonneville Power Administration

Environment, Fish and Wildlife

P.O. Box 3621

Portland, OR 97208-3621

Project Number 1997-030-00

Contract Number 04600

November 2003 


\title{
Chinook Salmon Adult Abundance Monitoring in Lake Creek, Idaho, 2002
}

\author{
2002 Annual Report
}

Prepared by:

Dave Faurot and Paul A. Kucera

\author{
Nez Perce Tribe \\ Department of Fisheries Resources Management \\ Lapwai, ID 83540
}

Prepared for:

U.S. Department of Energy

Bonneville Power Administration

Environment, Fish and Wildlife

P.O. Box 3621

Portland, OR 97208-3621

Project Number 1997-030-00

Contract Number 04600

July, 2003 


\begin{abstract}
Underwater time-lapse video technology has been used to monitor adult spring and summer chinook salmon (Oncorhynchus tshawytscha) escapement into the Secesh River and Lake Creek, Idaho, since 1998. Underwater time-lapse videography is a passive methodology that does not trap or handle this Endangered Species Act listed species. Secesh River chinook salmon represent a wild spawning aggregate that has not been directly supplemented with hatchery fish. The Secesh River is also a control stream under the Idaho Salmon Supplementation study.
\end{abstract}

This project has successfully demonstrated the application of underwater video monitoring to accurately quantify chinook salmon abundance in Lake Creek in 1998, 1999, 2001 and 2002. The adult salmon spawner escapement into Lake Creek in 2002 was 410 fish. Jack salmon comprised 7.1 percent of the run. Estimated hatchery composition was 6.1 percent of the spawning run. The first fish passage on Lake Creek was recorded on June 26, 15 days after installation of the fish counting station. Peak net upstream movement of 41 adults occurred on July 8. Peak of total movement activity was August 18. The last fish passed through the Lake Creek fish counting station on September 2. Snow pack in the drainage was $91 \%$ of the average during the winter of 2001/2002.

Video determined salmon spawner abundance was compared to redd count expansion method point estimates in Lake Creek in 2002. Expanded index area redd count and extensive area redd count point estimates in 2002, estimated from one percent fewer to 56 percent greater number of spawners than underwater video determined spawner abundance. Redd count expans ion methods varied from two percent fewer to 55 percent greater in 2001, 11 to 46 percent fewer in 1999 and 104 to 214 percent greater in 1998. Redd count expansion values had unknown variation associated with the point estimates. Fish per redd numbers determined by video abundance and multiple pass redd counts of the larger extensive survey areas in Lake Creek have varied widely. In 2002 there were 2.05 fish per redd. There were 2.07 fish per redd in 2001, 3.58 in 1999 and in 1998, with no jacks returning to spawn, there were 1.02 fish per redd.

Migrating salmon in Lake Creek exhibited two behaviorally distinct segments of fish movement in 2002. Mainly upstream only movement of both sexes characterized the first segment. The second segment consisted of upstream and downstream movement with less net upstream movement and appeared to correspond with the time of active spawning. The fish counting stations did not impede salmon movements, nor was spawning displaced downstream. Fish moved freely upstream and downstream through the fish counting structures. The downstream movement of salmon afforded by this fish counting station design may be an important factor in the reproductive success of listed salmon.

This methodology provides more accurate salmon spawner abundance information than expansion of single-pass and multiple-pass redd counts. Accurate adult escapement information would allow managers to determine if recovery actions benefited listed chinook salmon in tributary streams. 


\section{TABLE OF CONTENTS}

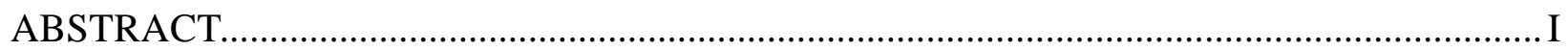

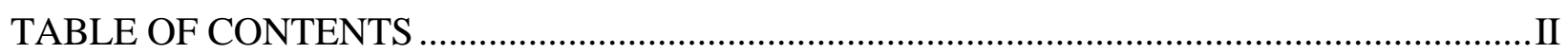

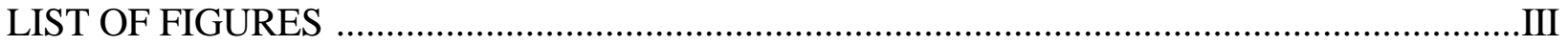

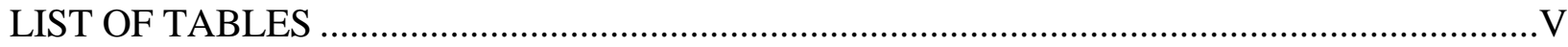

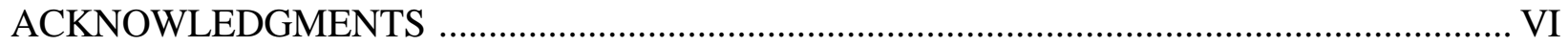

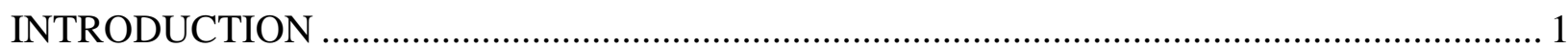

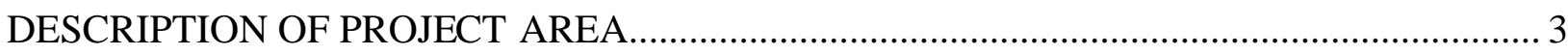

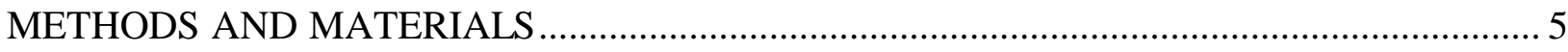

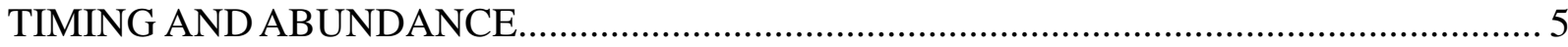

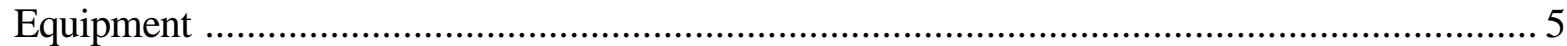

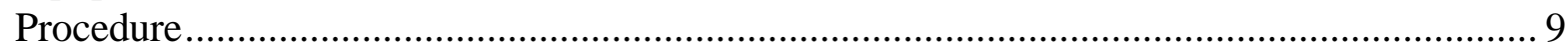

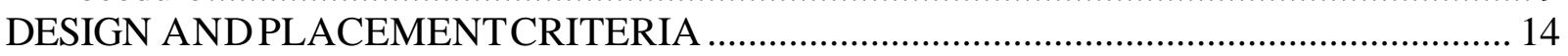

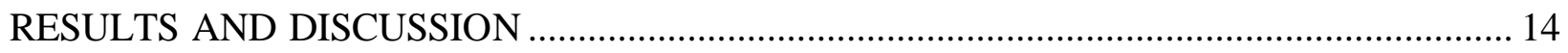

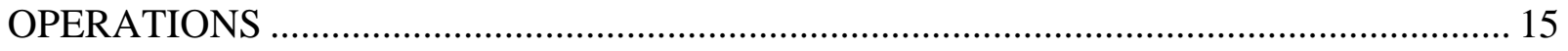

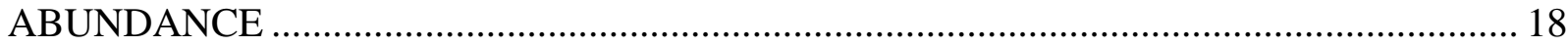

POTENTIAL SOURCE OF ERRORS IN UNDERWATER VIDEO MONITORING ..............2 20

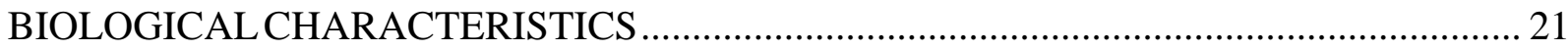

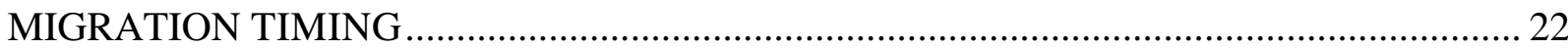

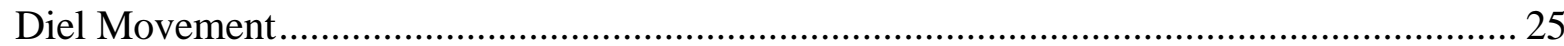

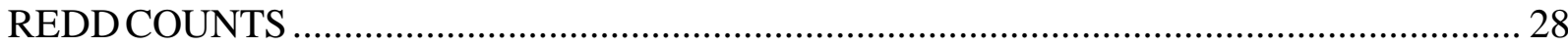

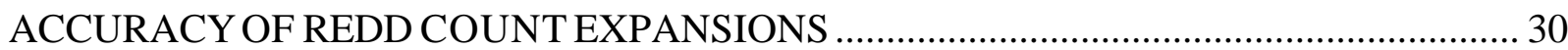

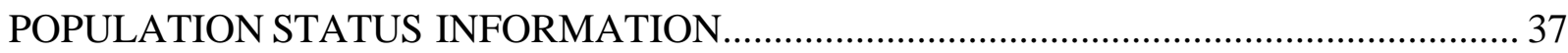

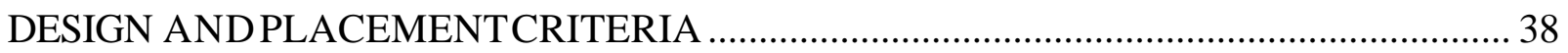

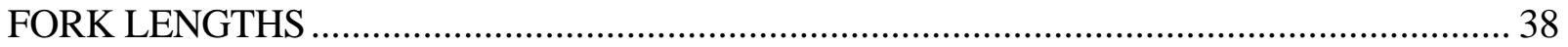

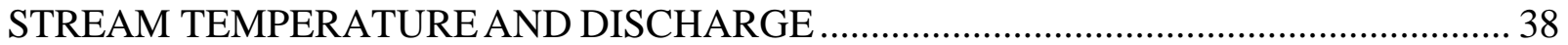

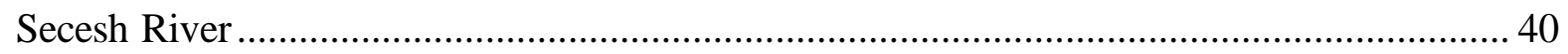

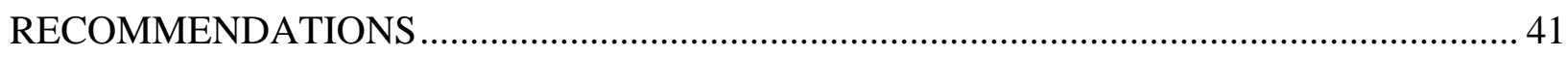

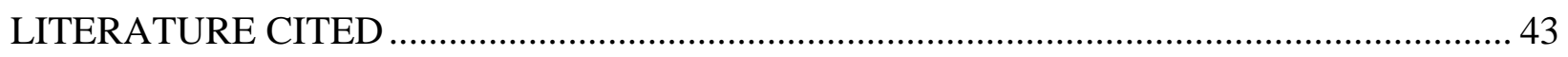

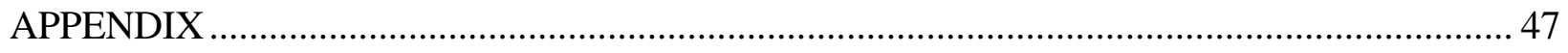




\section{LIST OF FIGURES}

Figure 1. Map of the Secesh River drainage and locations of the fish counting stations

(*denotes fish counting station). 4

Figure 2. Artist's rendition of the underwater video fish counting station demonstrating

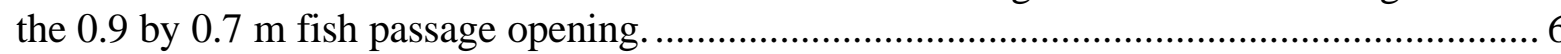

Figure 3. Lake Creek underwater fish counting station.................................................... 6

Figure 4. Temporary tripods, pickets and stringers used on the fish guiding fence. ................. 7

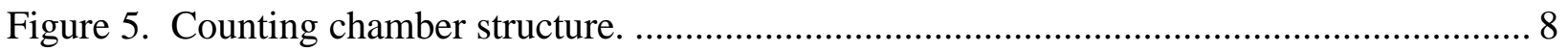

Figure 6. Camera and adjustable mounting bracket........................................................ 9

Figure 7. Underwater video photograph of a male chinook salmon migrating through the

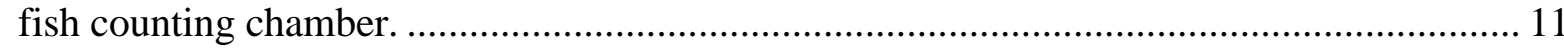

Figure 8. Underwater video photograph of chinook salmon migrating through the fish counting chamber at night.

Figure 9. Underwater video photograph of multiple (4) chinook salmon migrating through the fish counting chamber. The salmon in the foreground is missing the adipose fin.

Figure 10. Adult chinook salmon with narrow laser lines. Upside down image is a reflection from the water surface.

Figure 11. Adult chinook salmon with wide laser lines. Upside down image is a reflection from the water surface.

Figure 12. Adult chinook salmon abundance in Lake Creek, Idaho, 1998, 1999, 2001 and 2002

Figure 13. Net upstream spawning migration of adult spring and summer chinook salmon migrating through the Lake Creek fish counting station from 1998 to 2002.

Figure 14. Cumulative observed adult spring and summer chinook salmon spawner escapement at the Lake Creek fish counting station in 2002.

Figure 15. Daily net upstream and total movements of adult spring and summer chinook salmon through the Lake Creek fish counting station in 2002.

Figure 16. Diel timing of total activity (upstream plus downstream movements) of adult spring and summer chinook salmon through the Lake Creek fish counting station in 2002 . 
Figure 17. Diel timing of net upstream movement (upstream minus downstream) of adult spring and summer chinook salmon through the Lake Creek fish counting station in 2002.

Figure 18. Diel timing of upstream only movement of adult spring and summer chinook

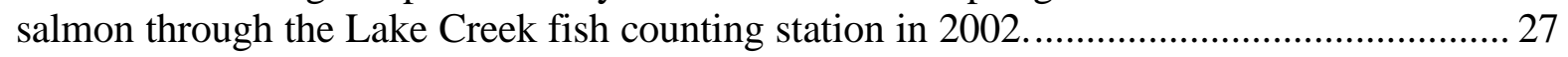

Figure 19. Comparison of IDFG and NPT redd cunts on Johnson Creek, 1987 to $1999 . \ldots \ldots \ldots . . .29$

Figure 20. Mean fish per redd estimates based on regression analysis. ................................ 31

Figure 21. Estimated percent difference of various chinook salmon redd count expansion methods, by year, when compared to Lake Creek spawner abundance estimates in 1998, 1999, 2001 and 2002.

Figure 22. Estimated percent difference of various chinook salmon redd count expansions, by method, when compared to Lake Creek spawner abundance in 1998, 1999, 2001 and 2002.

Figure 23. Carcass and laser determined length frequency distributions of adult spring and summer chinook salmon in Lake Creek in 2002.

Figure 24. Chinook salmon net upstream escapement, daily average stream temperature and stream discharge at the Lake Creek fish counting station in 2002. 39

Figure 25. Failed Secesh River fish counting station. 


\section{LIST OF TABLES}

Table 1. Summary of major chinook salmon escapement dates in Lake Creek, 1998 to 2002

Table 2. Potential sources of error in video abundance estimation methodology in Lake Creek in 2002 .

Table 3. Percent of wild adult spring and summer chinook salmon counted over Lower Granite Dam that spawned in Lake Creek and the Secesh River watershed, in 1998 to 2002 (TAC Biological Assessment Tables, corrected).

Table 4. Number and proportion of chinook salmon jacks in the Lake Creek spawning migration 1998 to 2002 .

Table 5. Approximate dates of change between the first and second segments of the chinook salmon spawning migration in Lake Creek and the Secesh River, 1998 to 2002 .

Table 6. Fish per redd in Lake Creek compared to data from the Imnaha River and Lookingglass and Johnson creeks.

Table 7. Comparison of video obtained adult spring and summer chinook salmon abundance to expanded redd count estimates in Lake Creek, Idaho, 1998 - 2002

Table 8. Adult chinook salmon spawner estimates for Lake Creek, the Secesh River excluding Lake Creek, and entire Secesh River, 1998 to 2002.

Table A-1. Run timing and direction of the spring and summer chinook salmon spawner migration in Lake Creek in 2002.

Table A-2. Diel movements of adult spring and summer chinook salmon passing through the Lake Creek fish counting station, by hour, in 2002.

Table A-3. Dates of net upstream migration and total movements of adult spring and summer chinook salmon through the Lake Creek fish counting station in 2002.

Table A-4. Corrections for turbidity and equipment downtime at the Lake Creek fish counting station, 2002. 


\section{ACKNOWLEDGMENTS}

The Bonneville Power Administration provided funding for this project. We would like to thank Tom Bumstead for engineering design, Rick Orme for assistance with statistical and graphical presentation, and Nez Perce Department of Fisheries Resources Management personnel, Mike Busby, Mitch Daniel, Dan Felt, Rob Hill, Rick Orme, Toby Tabor, Ryan Kinzer and Travis Kovel for project operations and structure placement. John Hintz of the Nez Perce Tribe furnished the map of the Secesh River drainage. We also appreciate the Nez Perce Tribe for administration of this project. 


\section{INTRODUCTION}

Salmon recovery within the Columbia River basin has become a focal point in the Pacific Northwest. Congress directed an independent scientific review of the Northwest Power Planning Council's (NWPPC) Fish and Wildlife Program activities because earlier programs were criticized as being a list of separate unrelated measures without any underlying scientific foundation (Independent Scientific Group 1993, Williams et al. 1998). Large amounts of time, effort and funding have been spent to improve fish passage conditions, augment flows, enhance and restore habitat, constrain harvest and use hatchery supplementation to increase salmon populations. Despite these efforts, salmon populations have continued to decline. The National Marine Fisheries Service has issued a Biological Opinion for the operation of the federal Columbia River power system (NMFS 2000) that attempts to define reasonable and prudent actions and criteria/population levels that would ensure continued existence of critical fish stocks. Recovery abundance levels are defined in terms of numbers of naturally spawning adult salmon returning to spawning areas. Therefore, accurate determination of adult salmon spawner abundance is of utmost importance to fisheries managers. Within the South Fork Salmon River, Secesh River spring and summer chinook salmon (Oncorhynchus tshawytscha) represent a wild salmon spawning aggregate. An analysis of Secesh River chinook salmon annual redd count data from 1957 to 1995 described a long-term population trend in significant decline $(\mathrm{p}<0.01)$ (Kucera and Blenden 1999). With the increase in abundance since 2000, the relationship is no longer significant. The Secesh River is currently used as a control system for the Idaho Salmon Supplementation studies (Bowles and Leitzinger 1991).

Spring and summer chinook salmon in the entire Snake River basin, including the Secesh River, are listed as threatened under the Endangered Species Act (ESA) (NMFS 1992). The Biological Opinion for operation of the federal Columbia River power system (NMFS 2000) recommended that accurate assessment of spawner escapement of listed Evolutionary Significant Units (ESU) are required for determining the characteristics, viability, recovery status, and delisting of ESU's under ESA. NMFS (2000) further defined the degree to which species-level biological requirements must be met: "At the species level, NMFS considers that the biological requirements for survival, with an adequate potential for recovery, are met when there is a high likelihood that the species population will remain above critical escapement thresholds over a sufficiently long period of time. The particular thresholds, recovery levels, and time periods must be selected depending upon the characteristics and circumstances of each salmon species under consultation (NMFS 2000)". The recovery metric for listed ESUs is the likelihood that the 8-year geometric mean abundance of natural spawners in a population will be equal to or greater than an identified recovery abundance level (NMFS 2000). NMFS interim abundance and productivity targets for South Fork Salmon River chinook salmon are 9,204 adults and a geometric mean cohort replacement rate that exceeds one, during the eight years immediately prior to delisting (NMFS 2000).

The NMFS recommended characterizing populations by abundance/productivity, diversity (viability), spatial structure, and habitat capacity (NMFS 2000), most of which 
rely on some quantitative measure of adult abundance. Adult abundance determination is also a necessary component of proposed short-term stock performance measures that focus on life history stages (NMFS 2000). The Validation Monitoring Panel (Botkin et al. 2000) provided a science-based analysis for monitoring of salmon for conservation plans. The panel also identified the need for accurate adult salmon abundance information in relation to conservation and restoration plans.

Determination of adult spawner abundance information is a critical aspect of a viable population management strategy (Foose et al. 1995, Botkin et al. 2000), which is recognized within the scientific community and in recovery planning efforts (NMFS 2000). Currently, there is limited quantitative information available to determine spawner abundance of spring and summer chinook salmon in tributary streams of the Snake River basin. Therefore, we cannot measure the effectiveness of conservation actions for a threatened species (Botkin et al. 2000). Quantifying adult salmon spawner abundance will provide a direct measurement of benefits of the Northwest Power Planning Council's Fish and Wildlife Program projects (funded by BPA) and efforts of recovery alternatives.

Traditional chinook salmon index area redd count surveys conducted in Idaho since the mid 1950's have relied upon one-time counts at the peak of spawning (Elms-Cockrum 1999). The purpose of these redd counts was to provide an index of relative abundance and population trend information over time. Recent surveys on some streams have used multiple ground counts of spawning activities for more accurate assessment of salmon redds (Kucera 1987, Cowley and Kucera 1989, Kucera and Banach 1991, Kucera and Blenden 1994, Kucera and Blenden 1999). Expansion of redd counts to spawner numbers are influenced by measurement error and uncertainty of assumptions regarding estimates of fish per redd, relative numbers in surveyed and unsurveyed areas, prespawning mortality rates, age composition, and hatchery fish composition (Beamesderfer et al. 1998). Neither of these redd count survey techniques was intended to provide accurate spawner abundance information. In addition, unknown error (variation) is associated with the redd count expansion.

Existing adult weirs are another potential source of adult spawner abundance information. The primary purpose of permanent and temporary adult weirs is for hatchery broodstock collection. Adult broodstock collection weirs are not sited for monitoring adult spawner abundance in streams. They most often provide either a minimum spawner estimate or a mark recapture spawner estimate derived from marked fish carcass recovery from spawning grounds. These estimates are also affected by measurement error and uncertainty of assumptions.

This investigation began in 1991 with planning and conceptual engineering design of an adult fish counting facility on the lower Secesh River (Fish Management Consultants 1991) funded through the Pacific Salmon Commission. Listing of the species under the Endangered Species Act in 1992, and concerns with a permanent facility and handling of fish prompted the search for a site where temporary facilities could be used. Preliminary design work followed in 1994 (River Masters Engineering 1994). The Nez Perce Tribe 
has worked cooperatively with the Idaho Department of Fish and Game (IDFG) and the U.S. Forest Service (USFS) in the planning and developmental stages of this project.

Technology is available that may improve the accuracy of salmon spawner escapement estimates. Time-lapse video has been used primarily to enumerate adults at fish counting/viewing windows at hydroelectric projects (Hatch et al. 1994a, 1994b). In some cases, cameras have been submerged in fish ladders to evaluate fish passage (USFWS, unpublished data). Limited studies have used cameras underwater in a natural setting. Holubetz and Leth (1996) experimentally operated a similar natural stream, remote video recorder system on Running Creek, in the headwaters of the Selway River, Idaho. Studies in Alaska have used time- lapse video cameras from above the stream (Otis Alaska Department of Fish and Game, Homer, personal communication), in conjunction with a fishwheel (Daum U. S. Fish and Wildlife Service, Fairbanks, personal communication) and underwater in a stream (Hetrick U. S. Fish and Wildlife Service, King Salmon, personal communication)

Information collected from this project will provide accurate salmon spawner abundance information to managers necessary to fulfill requirements of the NMFS 2000 Biological Opinion (NMFS 2000) and will allow comparison to redd count survey data to assess if redd count information provides reliable indices of adult salmon escapement.

The goal of this project is to accurately assess the spring and summer adult chinook salmon spawning migration in the Secesh River and Lake Creek drainages. This is a goal of the Nez Perce Tribe for all anadromous waters within their ceded territory. This goal emphasizes collection of tributary specific adult salmon spawner abundance information. We believe accurate abundance numbers are necessary when dealing with an ESA listed species to manage and to assess recovery actions. Adult abundance information is presently collected from Lower Granite Dam counts, instream fish weirs, hatchery racks and tributary redd counts. Presently, an index of relative abundance is estimated from index area or multiple pass extensive redd count data in the Secesh River and Lake Creek. These streams have never been supplemented and as such represent control streams under the Idaho Salmon Supplementation Studies.

The objectives of the study were to:

1) Accurately determine adult spring and summer chinook salmon spawner abundance in the Secesh River and Lake Creek on an annual basis.

2) Determine the timing of adult spring and summer chinook salmon spawning migration into the Secesh River and Lake Creek drainages.

3) Determine the accuracy of redd count methodology compared to the underwater video escapement enumeration technique.

\section{DESCRIPTION OF PROJECT AREA}

The Secesh River watershed covers 688 square $\mathrm{km}$ in west central Idaho, (Figure 1). The Secesh River is formed at the junction of Summit and Lake creeks, and traverses $45 \mathrm{~km}$ to the southeast where it flows into the main stem South Fork Salmon River about 


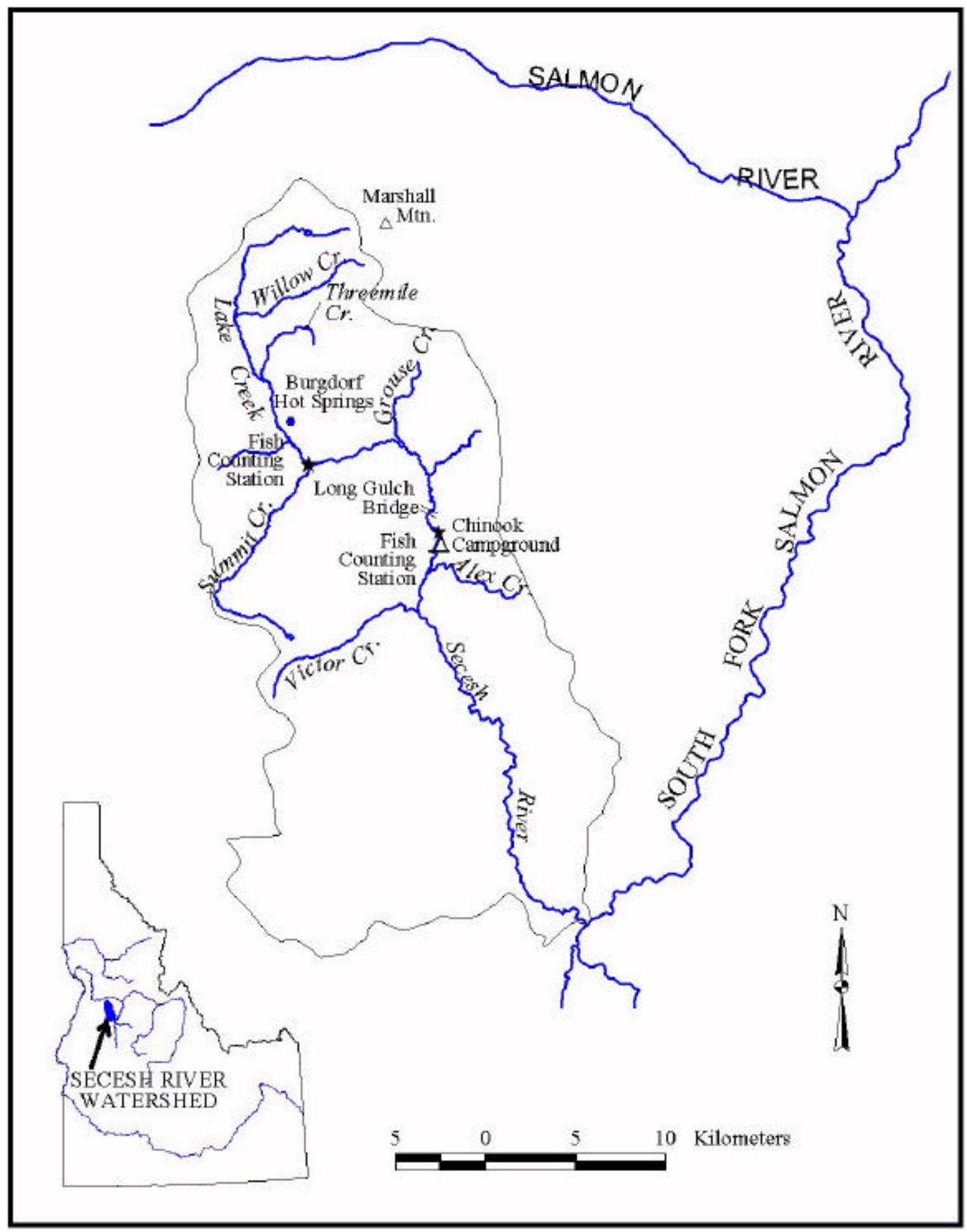

Figure 1. Map of the Secesh River drainage and locations of the fish counting stations (*denotes fish counting station). 
two km downs tream of the East Fork South Fork of the Salmon River (Figure 1).

Headwaters of Lake Creek are in the mountains above Burgdorf at an elevation of 2,417 m. Lake Creek drains an area of approximately 90 square $\mathrm{km}$, is $25 \mathrm{~km}$ in length and is approximately $15 \mathrm{~m}$ wide at the fish counting station. Elevation drops to 1,838 $\mathrm{m}$ where Lake Creek joins Summit Creek to form the Secesh River. Elevation of the Secesh River then drops to 1,110 m where it flows into the South Fork Salmon River. Channel gradients range from less than one percent along Lake Creek and the upper Secesh Meadows to over 10 percent in canyon sections. Average gradient in the vicinity of the fish counting stations was 0.5 percent. The Secesh River fish counting station was located $30 \mathrm{~km}$ upstream from the South Fork Salmon River at the U. S. Forest Service's Chinook Campground. The Lake Creek fish counting station was located $45 \mathrm{~km}$ upstream from the South Fork Salmon River and $100 \mathrm{~m}$ upstream from the mouth of Lake Creek. In addition to chinook salmon, the Secesh River drainage contains resident and steelhead trout (O. mykiss), westslope cutthroat (O. clarki lewisi), bull (Salvelinus confluentus) and brook (S. fontinalis) trout, mountain whitefish (Prosopium williamsoni), longnose dace (Rhinichhys cataractae) and sculpin (Cottus sp.). The major chinook salmon spawning habitat was located upstream of the fish counting station in Secesh Meadows, in lower Grouse and Summit creeks and in Lake Creek from Burgdorf Meadows upstream to Willow Creek. Additional spawning area existed upstream of Willow Creek. There was minimal chinook salmon spawning habitat from the mouth upstream $27.5 \mathrm{~km}$ to the upper end of the canyon area and limited spawning habitat from the upper end of the canyon, upstream to the Secesh River fish counting station.

\section{METHODS AND MATERIALS}

\section{TIMING AND ABUNDANCE}

\section{Equipment}

This project involved an ESA listed species that has a population trend in long-term decline. It was important to allow these fish to migrate and spawn without harassment. Underwater video used a passive, non-invasive system that allowed complete freedom of upstream and downstream movement of fish. Fish were not trapped, handled or held at any time. Primary system components were the temporary structure and the video equipment. The structure included tripod supported upstream and downstream picket guide fences and a counting chamber (Figures 2 and 3). The structures were shaped like two "V"s connected at their apexes by the counting chamber (Figure 3). The two downstream wings were angled at 30 to 45 degrees to the bank to orient and direct upstream migrating fish through the counting chamber. The two upstream wings did the same for downstream moving fish. The counting chamber was located in the thalweg, which was believed to be the preferred migration route. The entrance to the counting chamber was $0.9 \mathrm{~m}$ wide by, $0.7 \mathrm{~m}$ high. Upstream and downstream migrating adults were able to move freely into and through the counting chamber. 


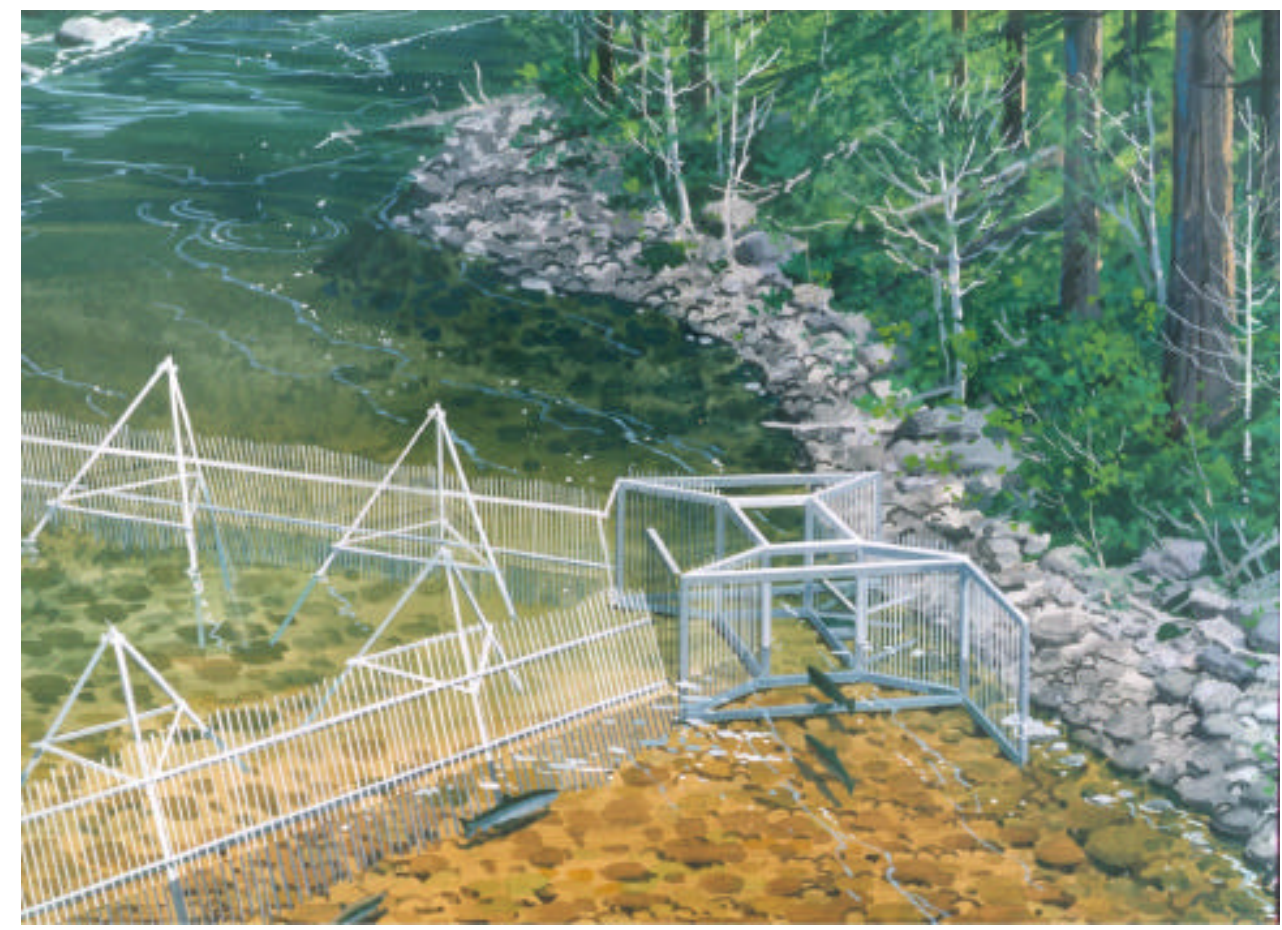

Figure 2. Artist's rendition of the underwater video fish counting station demonstrating the 0.9 by $0.7 \mathrm{~m}$ fish passage opening.

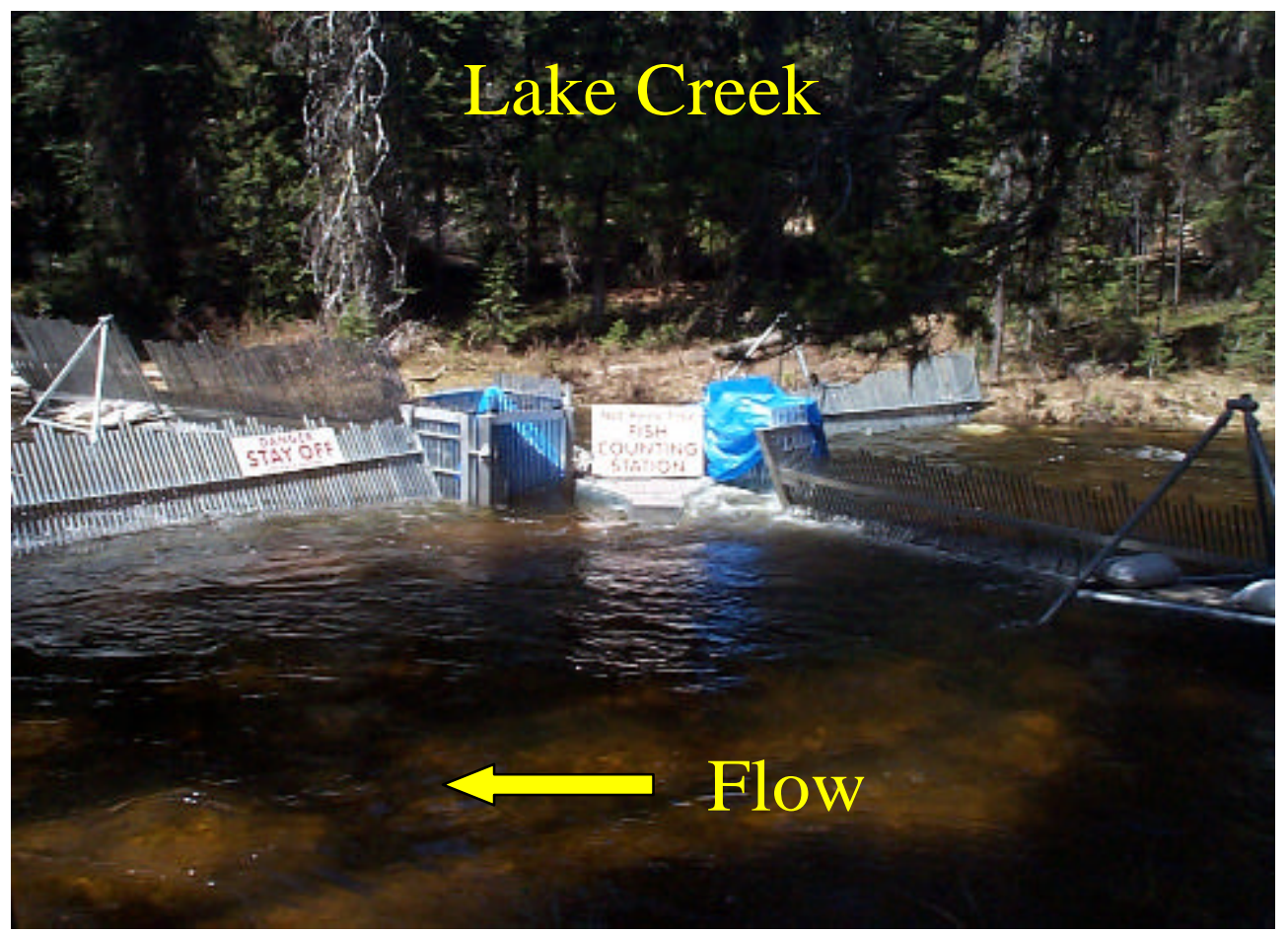

Figure 3. Lake Creek underwater fish counting station 
Construction of the temporary fish guiding structure was modeled after the standard Alaska picket weir (Figure 4). Structure tripods were constructed of $3.81 \mathrm{~cm}$ galvanized steel pipe with Kee Klamp® structural pipe fittings. Support brackets were attached to a tripod leg to support the picket stringers. Picket stringers were constructed of $0.64 \mathrm{~cm}$ aluminum angle with $2.54 \mathrm{~cm}$ diameter holes punched $5.08 \mathrm{~cm}$ on center. After the

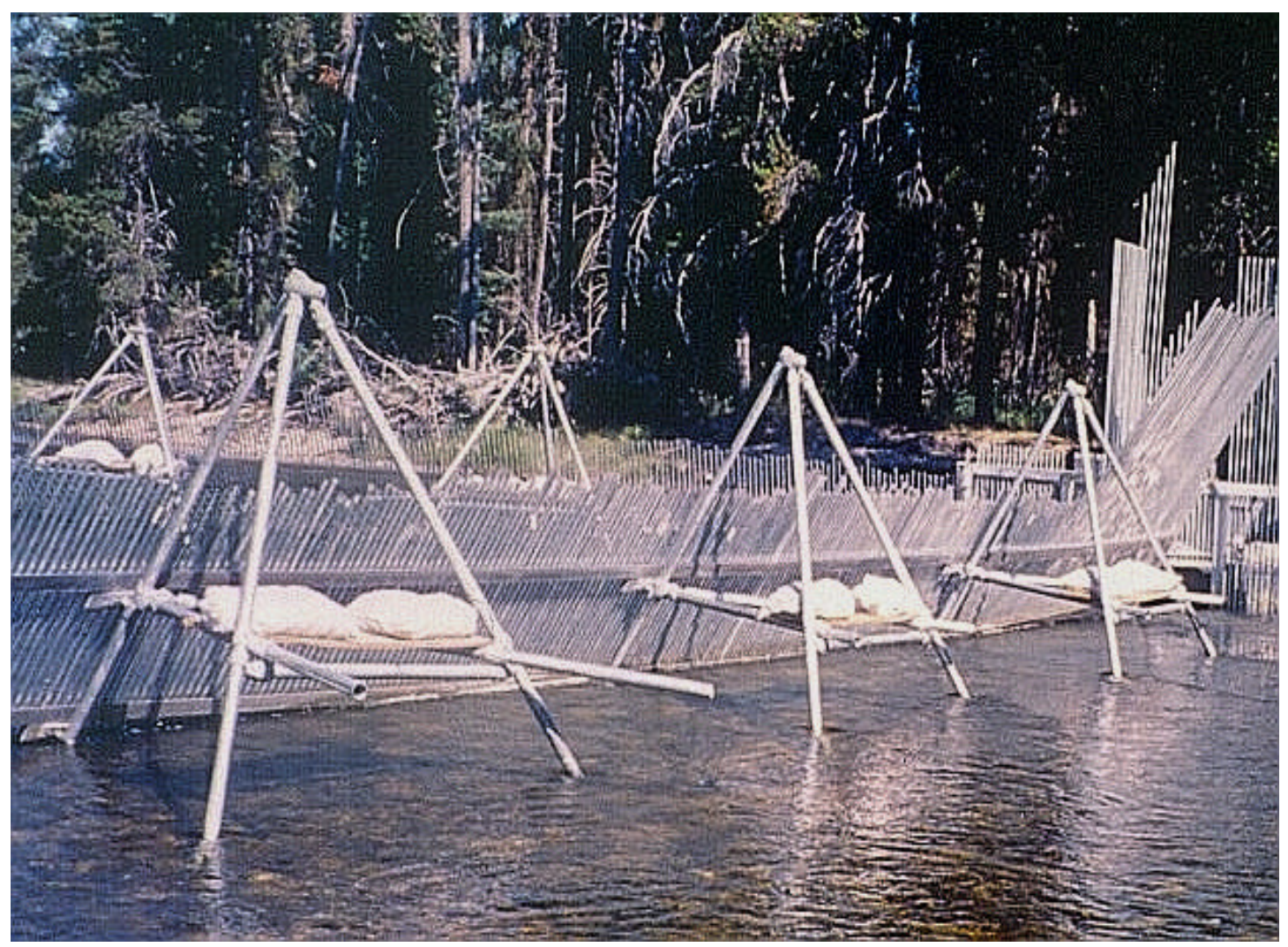

Figure 4. Temporary tripods, pickets and stringers used on the fish guiding fence.

tripods, support brackets and stringers were set in their final positions; $2.54 \mathrm{~cm}$ aluminum conduit pickets were installed in the stringers. The fish counting chambers were constructed of angle aluminum with dimensions of $0.9 \mathrm{~m}$ wide by $1.2 \mathrm{~m}$ long by $0.8 \mathrm{~m}$ high (Figure 5) when viewed from the upstream or downstream end. Aluminum pickets were placed in the counting chamber frames above the passageway to prevent movement through the counting chambers above the viewing area. A transition section was located on both ends of the counting chambers to direct fish into the chambers. Transitions tapered from $0.9 \mathrm{~m}$ wide by $1.4 \mathrm{~m}$ high at the counting chambers to $2.1 \mathrm{~m}$ wide by $1.4 \mathrm{~m}$ high at the outer edge. Distance from the counting chambers to the outer edge of the transition was $0.8 \mathrm{~m}$. The guide fences were attached to the counting chambers and transitions with adjustable wing panels located at each outer corner of the transitions. Installation of the guide fences at any angle between 30 and 45 degrees was possible with the hinged wing panels. 


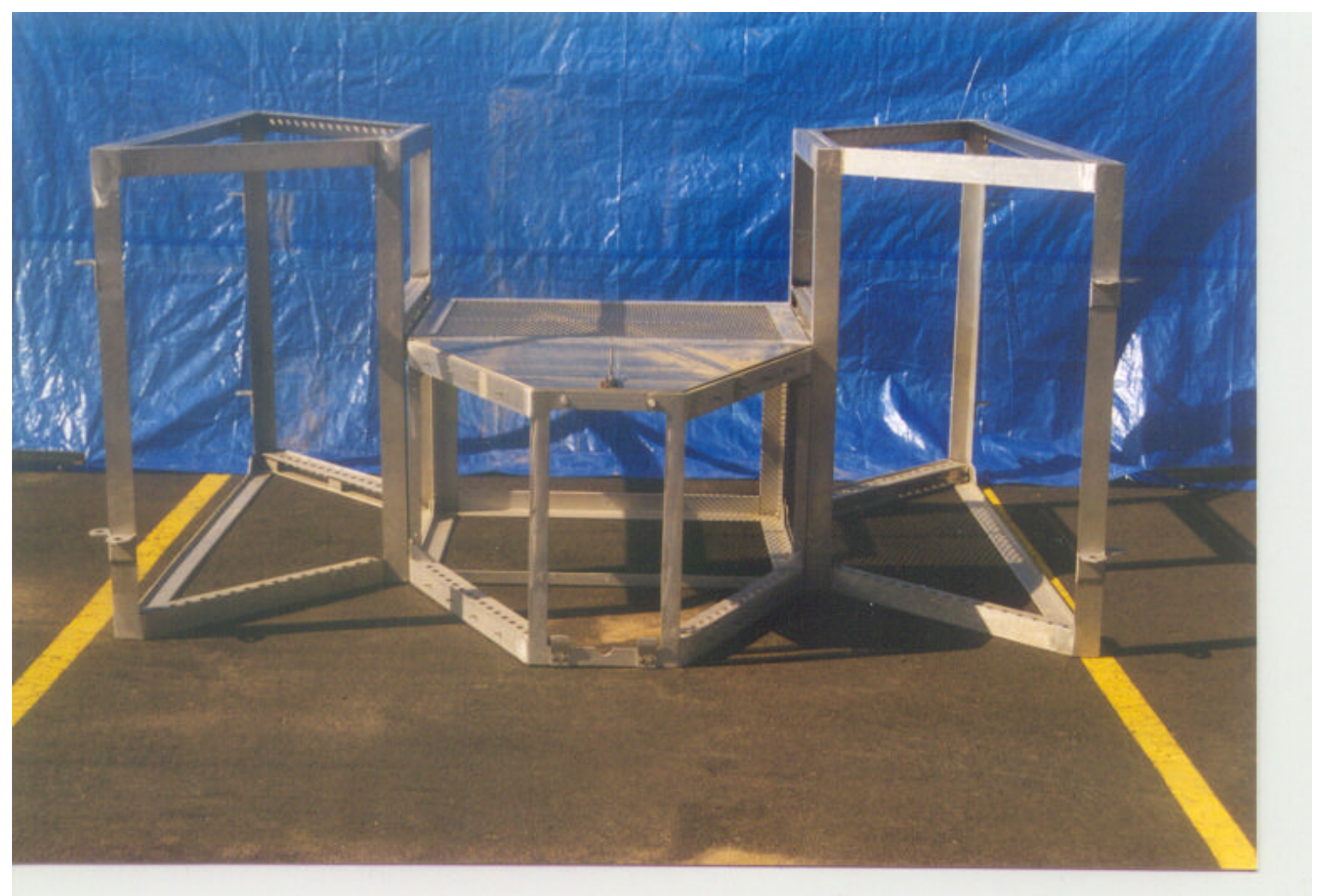

Figure 5. Counting chamber structure.

An adjustable camera platform (Figure 6) was located on the side of the counting chamber. This adjustable platform allowed the camera to be moved up, down, forward and / or backward as the water level fluctuated to ensure the entire field of view in the counting chambers was recorded on the tape. The camera was positioned as close as possible to the bottom, while still including the entire field of view, to provide the best view of fish moving through the counting chamber. Photographs of individual salmon were taken through a clear Plexiglas ${ }^{\circledR}$ window mounted on the lower half of the counting chamber on the near side. On the far side of the counting chamber, an aluminum sheet, painted off white, was mounted on the lower half of the chamber to create a contrasting background for the photos.

Individual fish images were recorded in time-lapse (4.5 frames per second) on VHS videotape. A single VHS T-160 videotape will provide 32 hours of coverage at 4.5 frames per second. Recording occurred continuously while the counting stations were operating. Due to the remote location, the entire system used 12 volt DC supplied by 2 six-volt golf cart batteries and were charged by solar panels. Artificial red light was provided by two to four arrays of 36 Light Emitting Diodes (LEDs) that illuminated in the red portion of the light spectrum (approximately $690 \mathrm{~nm}$ ). Two six-volt golf cart batteries in series supplied power to the system. The entire system is 12 volt DC charged by solar panels. All connectors were waterproof O-ring sealed type. Photographs of 
individual salmon passages (Figures 7, 8 and 9) were re-recorded on a master VHS videotape.

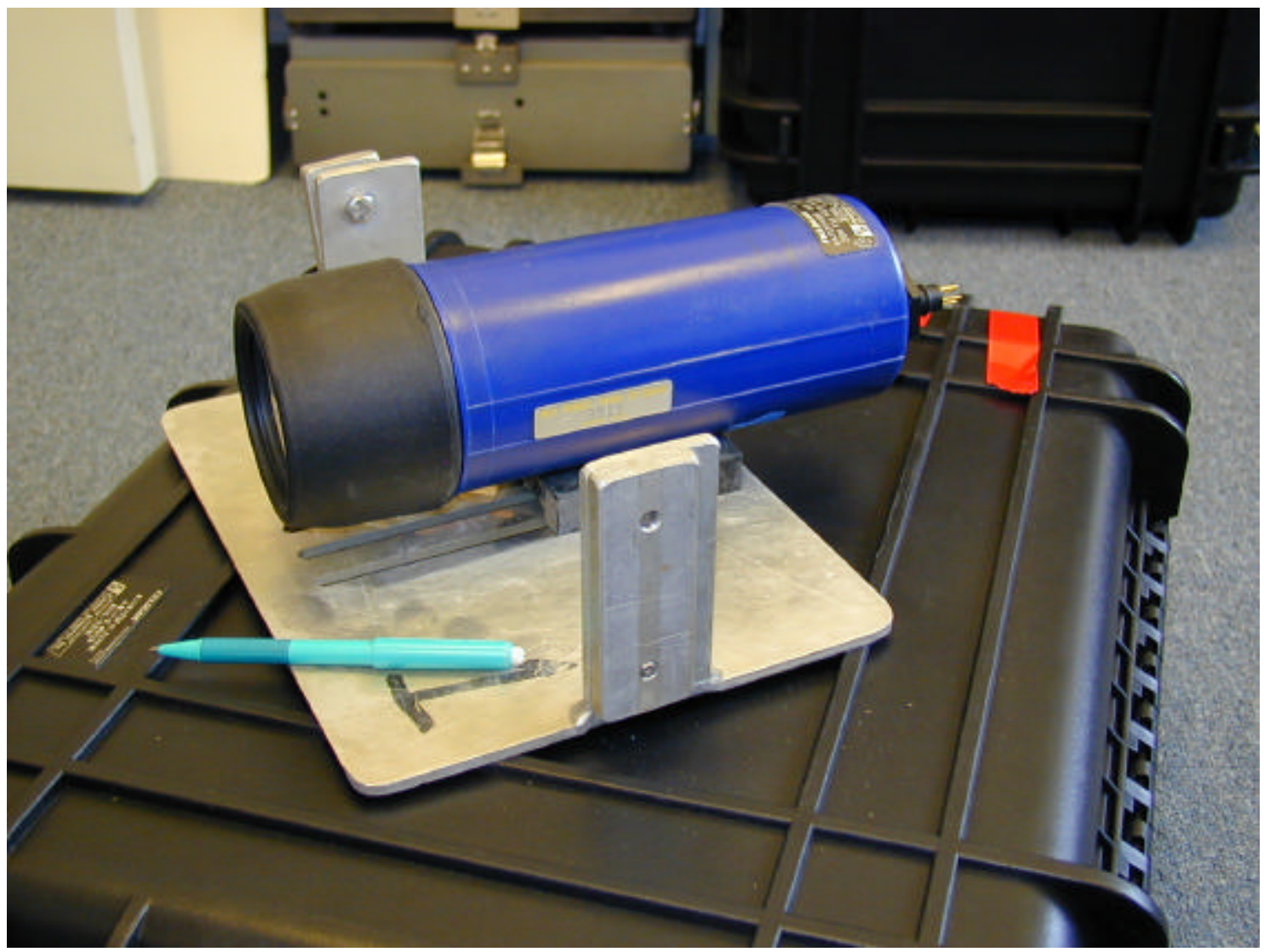

Figure 6. Camera and adjustable mounting bracket.

\section{Procedure}

Determination of net escapement during the course of the upstream migration was simply a matter of adding to the total as a fish passed upstream, and subtracting as a fish moved downstream. To minimize the impact of fish wandering while searching for a suitable spawning location, the fish counting station was placed downstream of as much spawning area as feasible. Females upstream of the fish counting station during the time of spawning were all assumed to have contributed to spawning. All males, even those that dropped out of the system after the peak of spawning, were assumed to have spawned. Thus, the greatest number of fish above the fish counting station after spawning commenced was considered to have contributed to spawning.

The video fish count was meant to be a complete count (census) of the adult salmon spawners. However, sources of error include fish that passed above the weir without going through the fish counting chamber, fish that were recorded on the videotape but 
missed by the tape reader and fish that were not recorded because they migrated through the counting chamber during periods of high turbidity or equipment downtime.

Considerable effort was put into making the weir fish tight. No fish were seen jumping at the weir and no fish were ever seen between the upstream and downstream wings on either side. We felt very confident that the weir was fish tight and assumed that no fish passed the fish counting station without passing through the counting chamber. There is no way to estimate this source of error.

A correction for tape viewer efficiency was determined by a stratified random sampling design. Weekly, a day of the week was randomly drawn from a hat and that day's videotape was read by two additional independent videotape readers. The combination of results of the three observers produced a complete net escapement. Net escapement observed by the original reader was compared to the complete net escapement. Because all readers reviewed the tapes until agreement was reached among the multiple readers, the correction had zero variance. Since upstream and downstream fish passages may not have been "missed" equally, the efficiency factor was applied to net movement. The tape-viewer efficiency correction number was applied at the end of the season (and was not used for discussions). This correction was not determined in 1998 and 1999 (Faurot et al. 2000 and Faurot and Kucera 2001a). Corrections to 1998 and 1999 results were made in the 2001 report (Faurot and Kucera 2001b) and have been continued in the 2002 report.

Short periods of system downtime were experienced during the 2002 field season. Most of these were caused by a failure of the solar panels to charge batteries after periods of cloudy weather. Outages were relatively short and passage correction factors were easily calculated (Appendix Table A-4). Corrections for downtime were made by using an hourly average of fish passages, during the hours of the outage, two days prior to and two days after the outage. This hourly average was then multiplied by the number of hours of the outage. The downtime correction was applied as it occurred. Fish numbers discussed in this report have had the downtime correction applied.

Redd counts within the Secesh River and Lake Creek were conducted independently by Nez Perce fisheries and IDFG personnel. The Nez Perce Tribe conducts multiple pass surveys of index areas and larger intensive survey areas. The IDFG conducts one pass surveys of index areas near the height of spawning activity. Multiple pass surveys usually entail three to five surveys, one at the beginning of the spawning period, and the last after spawning has been completed. Index survey areas remain constant from year to year and are a small portion of the entire stream. Intensive area surveys include the index area, additional reaches on the main stem and, when present, tributaries. The fish per redd number is affected by the survey method. A single-pass redd count at a predetermined peak of spawning date will usually be less than a multiple-pass redd count covering the complete spawning period, and would produce a larger fish per redd number. Nez Perce Tribe multiple pass redd counts were used since they covered more of the stream and were more thorough. 
Personnel replaced videotapes and cleaned the weir structure daily. Although videotapes were capable of recording about 32 hours of information, they were changed daily. Batteries were replaced as necessary to ensure efficient project operation. In 2002, completed Lake Creek videotapes were taken immediately to the office and manually reviewed to ensure they had operated properly and recorded data. The computerized editing system for video monitoring of fish passage described in Hatch et al. (1998) did not work again for our system in 2002. Data obtained species, number of adult chinook salmon, date of passage, time of day of passage, direction of passage, estimated length and gender, and other marks such as fin clips or unique scars to identify individual fish (Figures 7, 8 and 9). A VHS master tape of just the actual fish passages was produced for further review and verification of data. The date-time stamp on the videotape provided date and time of passage. Direction of fish movement was noted as up or downstream. Species identification was fairly simple. All adult chinook salmon were $50 \mathrm{~cm}$ or larger. The only other fish to reach that size were whitefish, which were not a problem to differentiate from videotape images, and bull trout. Bull trout and jack chinook salmon were differentiated by the longer anal fin and flattened body form of bull trout.

Secondary identification characteristics were the squarer tail and erect dorsal fin of bull

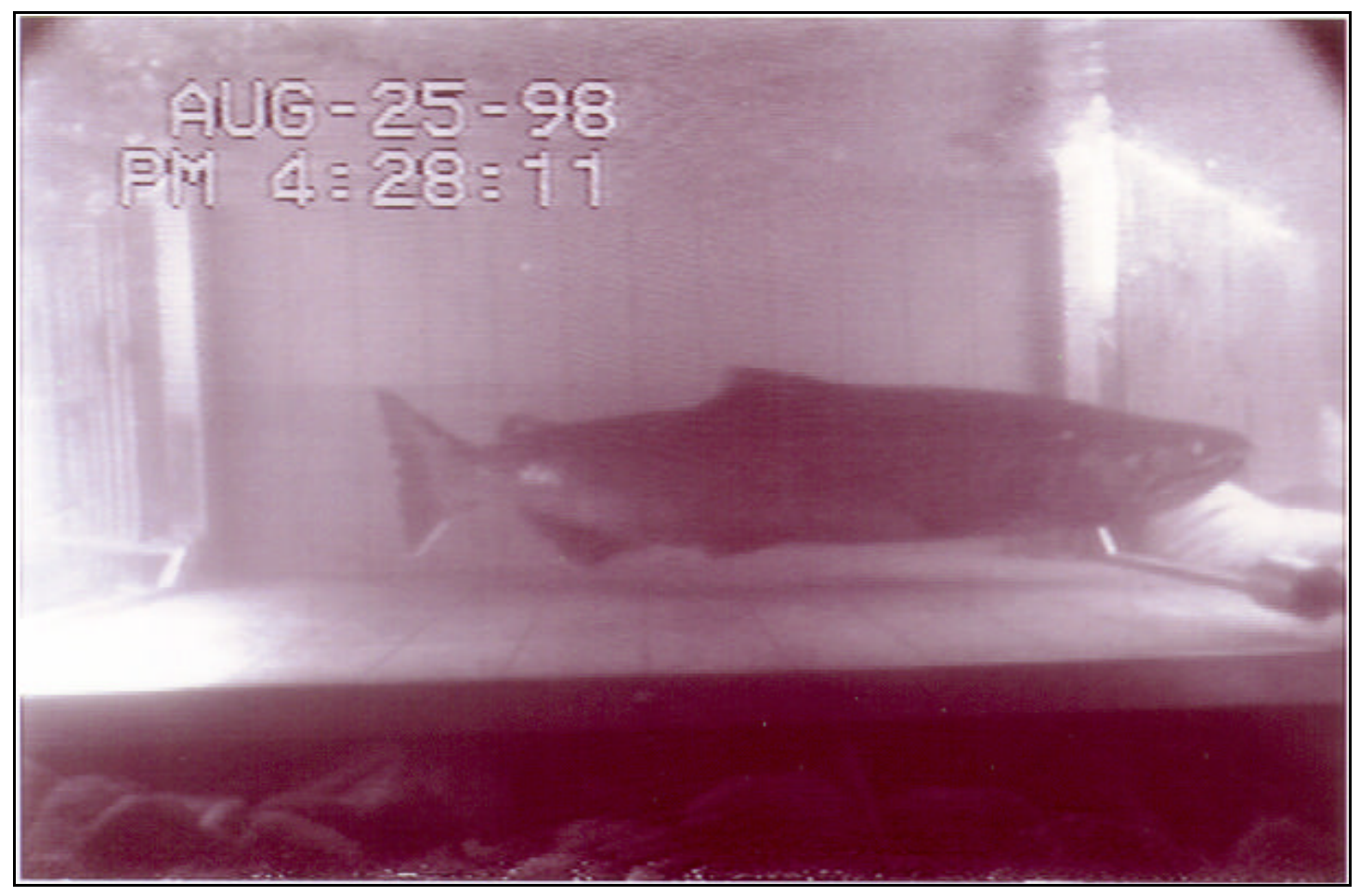

Figure 7. Underwater video photograph of a male chinook salmon migrating through the fish counting chamber. 


\section{JUN-24-01 AM1 2: 25: 51}

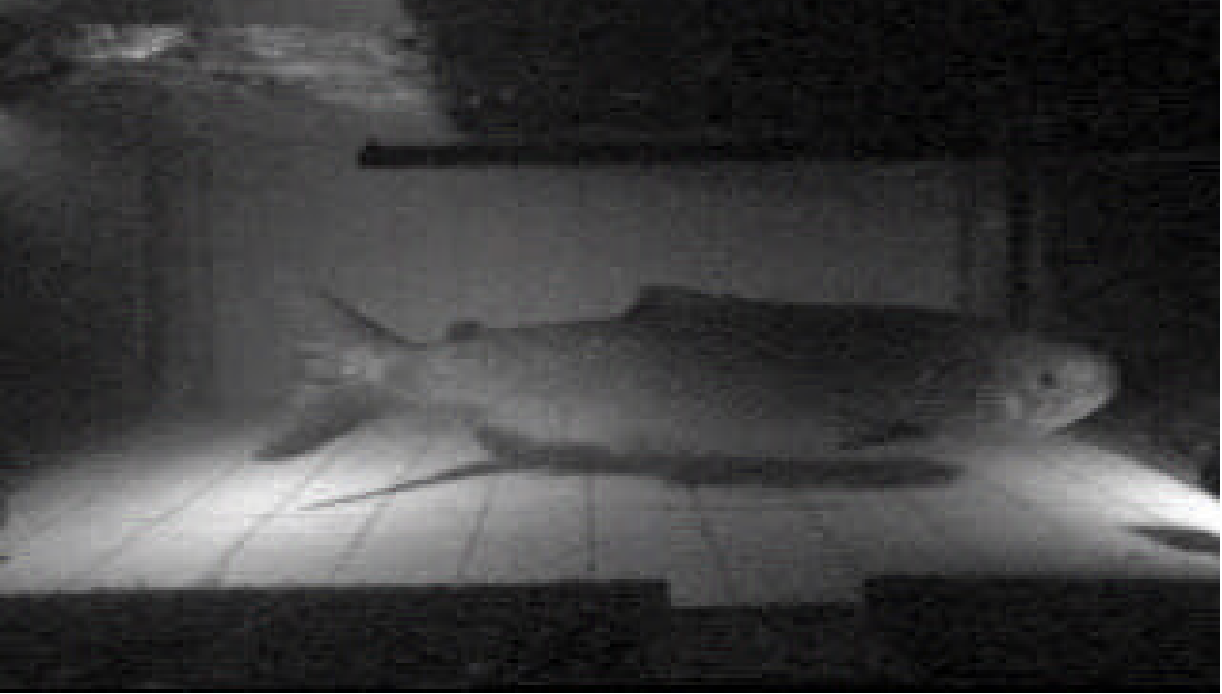

Figure 8. Underwater video photograph of chinook salmon migrating through the fish counting chamber at night.

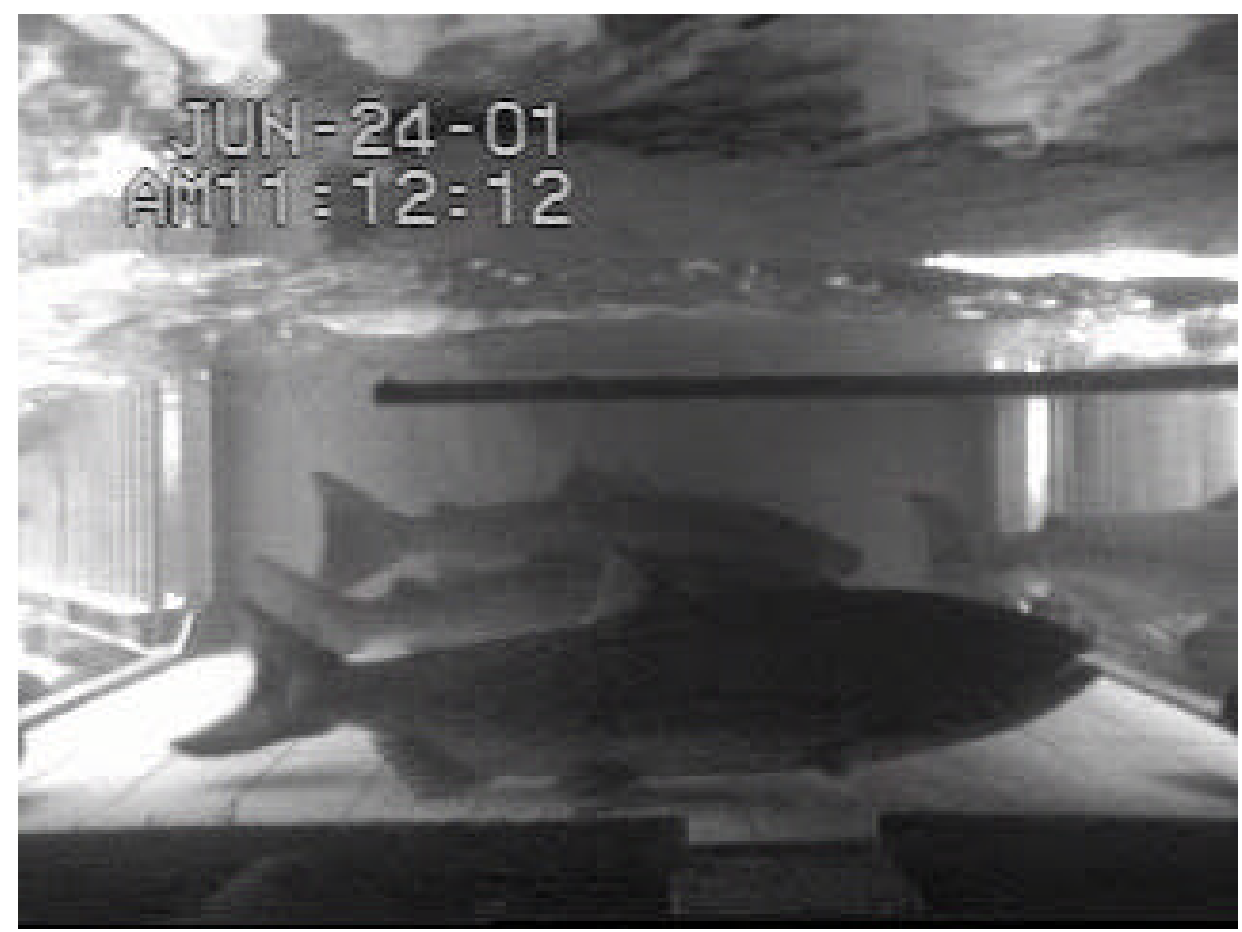

Figure 9. Underwater video photograph of multiple (4) chinook salmon migrating through the fish counting chamber. 
trout. Movements of bull trout $40 \mathrm{~cm}$ and larger were noted. Fish species identification of fish smaller than $40 \mathrm{~cm}$ was difficult and their movements were not recorded.

Lasers were used to measure fish lengths in 2002. Two lasers mounted parallel, $5 \mathrm{~cm}$ apart, produced two vertical parallel lines over an 80 degree arc that produced parallel lines on fish as they swam through the counting chamber (Figure 10). Fish length was determined by using proportions (distance between the two laser marks measured on the

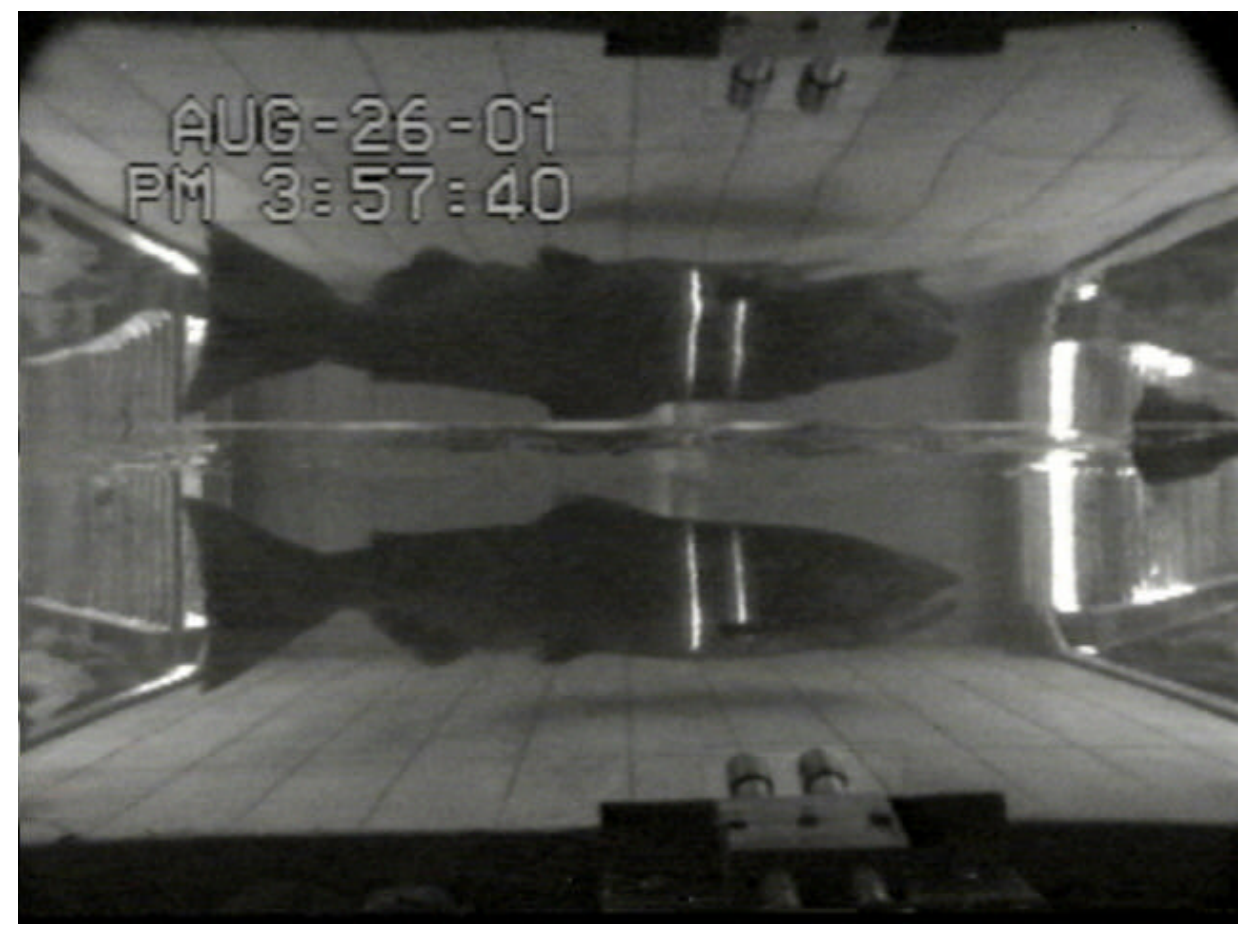

Figure 10. Adult chinook salmon with narrow laser lines. Upside down image is a reflection from the water surface.

monitor/actual distance between the two lasers $(5 \mathrm{~cm}))=($ fish length measured on the monitor/actual fish length) and solving for the unknown actual fish length. In previous years and as a backup method in 2002, fish lengths were determined by measuring fish against a $10 \mathrm{~cm}$ grid system that was marked on the bottom and back plates of the counting chamber. This resulted in an accuracy of $\pm 10 \mathrm{~cm}$, and was unsatisfactory.

One task within the original project was to estimate the number of hatchery strays into the system. Fin clips were noted to determine the number and percentage of hatchery chinook salmon in the run. The Idaho Department of Fish and Game (IDFG) McCall Fish Hatchery releases their fish into the upper South Fork Salmon River. All released smolts have received an adipose and/or a ventral fin clip. Ventral fin clips were hard to detect, especially on the side away from the camera. The requirement to enumerate strays was not accomplished in 1998 and 1999 (Faurot et al. 2000) due to the difficulty distinguishing between poor/partial fin clips and small or naturally damaged fins. This did not seem to be a problem in 2000, 2001, 2002, and adipose-clipped fish were counted. In 2002, McCall Fish Hatchery used an automated adipose fin clipping station 
that should have better quality adipose fin clips in future years returns. Most adult salmon with a missing adipose fin are assumed to be McCall Hatchery fish released into the South Fork Salmon River as smolts. Even though the McCall Fish Hatchery adipose fin clips all their fish, some hatcheries no longer adipose fin clip all of their released fish, therefore straying estimates would be minimums.

Visual characteristics were used for sex determination. The primary characteristic was the shape of the head and the development of the male kype. Sex composition of migrating adult salmon could not be determined positively early in the season. These characteristics became more pronounced as the migration progressed. A secondary aid to gender determination was the tendency of male chinook salmon to have a larger adipose fin.

Stream water temperatures were measured with a constant recording thermograph beginning June 26. Stream discharge was measured five times during the main part of spring runoff and on a weekly basis for the remainder of the season, using a Marsh McBirney model 2000 flow meter accuracy $\pm 0.01 \mathrm{fs} / \mathrm{ms}$.

\section{DESIGN AND PLACEMENT CRITERIA}

Operation of the fish counting station structure was compared to water depth and velocity criteria recommended by Hevlin and Rainey (1993). These criteria were examined relative to safety and structural integrity of the facility given the hydrologic conditions at the site. If the recommended criteria could not be safely met the facility would be removed and installed when the criteria were achievable. More importantly, the structure could determine what the criteria actually should be for the specific installation site. Total snow pack, rate of snow melt, and debris load all affect installation and operation of the fish counting stations.

\section{RESULTS AND DISCUSSION}

Fish that enter the Secesh River are believed to belong to two spawning aggregates, Secesh River and Lake Creek. Lake Creek fish must migrate upstream through the Secesh River to get to Lake Creek. Lake Creek fish are believed to enter first, move upstream to colder headwater areas, and begin spawning early to mid-August (NPT unpublished data). Secesh River fish spawn from mid August to early September. Observations from this project, especially in 1999 have indicated males may spawn with both Lake Creek and Secesh River spawning aggregates. This was not as noticeable in 2000, 2001 and 2002. The Secesh River/Lake Creek spawning aggregate has been in a long-term decline (Elms-Cockrum 1999), although the last three years have evidenced higher adult returns. The winter of 2001/2002 had a normal snowfall (91\% of average snow water equivalent) and spring runoff was normal.

We observed bull trout migrating through the fish counting station. Bull trout actively migrated upstream from June 25 through July 19. There was a lull in bull trout movement until August 18 when bull trout began migrating downstream. The downstream migration was still occurring when we ceased operation on September 9. 


\section{OPERATIONS}

As this project dealt with a threatened species, special efforts were made to reduce our impacts to the resources. Everything was designed to have minimal impact to the resources and the landscape. Fish were never trapped, handled or held. The structures were installed as soon as possible after the peak of spring runoff to have the fish counting chambers in place prior to the arrival of the first upstream migrating chinook salmon. Structures were temporary and could be installed and removed in a day. In NMFS standards for barrier/trap installations, Hevlin and Rainey (1993) describe numerous unanticipated adverse fish impacts associated with standard fish barriers and traps. These included trap rejection, fallback downstream and spawning below the barrier. In rare instances, spawning has been displaced to another tributary. These structures were usually constructed perpendicular to the stream bank with a small entrance, to prevent fish from escaping the trap once they had entered. The design of our temporary weir funneled fish into the passage opening from upstream and downstream with an opening $0.9 \mathrm{~m}$ wide. Fish were not restricted in passage, upstream or downstream. Each year fish made multiple passages (greater than 10), upstream and downstream, over a period of several days (Faurot and Kucera 1999, Faurot et al. 2000, Faurot and Kucera 2001a and 2001b, and Faurot and Kucera 2002). This design has been shown to be effective and should be incorporated in future weir designs where possible.

In 1999, we installed Lake Creek and Secesh River structures prior to spring runoff and both failed due to the high water and heavy debris load. Although the basic structure may have been able to withstand stream flows, the high water recruited a heavy debris load that had accumulated in the riparian area during previous lower flow years. Debris accumulated on the basic structure (tripods etc.) and it failed. Very little damage occurred to the structure as the tripods were tipped over and dislodged. This may be prevented by anchoring the front leg of the tripods to the substrate.

In our first year of operation at Lake Creek, 1998, the fish counting station was installed June 22 and the first fish arrived July 8. Snow pack was low in 1998 (72\% of normal), which allowed the county to plow open Secesh Summit earlier than the usual Memorial Day weekend opening. Even though 17 days elapsed without an adult chinook salmon passage, there were questions concerning an early spawning segment that might have arrived prior to structure installation. In 1999, an above normal snow pack year (148\% of normal), we decided to install the basic structure (no pickets) prior to spring runoff. The road was not open so materials were hauled in over the snow by snowmobile. Lake Creek installation occurred April 29. Spring runoff peaked in mid to late May. The structure failed on May 26 (Figure 25). The structure was recovered and the complete structure was reinstalled on July 9. Fish were not recorded on July 9 or 10. We assumed the first fish passage we documented on July 11 was the first fish of the run. In 2000, the complete Lake Creek structure was installed June 22, 16 days earlier than the arrival of our fish in the first two years of operation. Fish were recorded moving past the fish counting station immediately, indicating run timing could vary as much as three weeks. The fish counting station was installed during peak runoff in 2001. This was a low flow year (38\% of normal) and stream discharge at the time of installation was approximately 
$150 \mathrm{cfs}$. Installation occurred on May 22 and the first fish was not documented until June 22. This led us to believe there was not an earlier segment to the spawning migration. This was confirmed in 2002 by the 17 days of no fish passage after the June 11 installation. This also indicated run timing could vary as much as four weeks.

The South Fork Salmon River drainage (including Secesh River and Lake Creek) has a high percentage of surface fine sediments that may affect salmon reproductive success (Nelson et al. 2002). Over the past 20 years, the Payette National Forest has restricted activities that would contribute to sedimentation. Sandbags are routinely used to add weight to tripods, seal open areas between the substrate and pickets, fill the space between end of the pickets and the undercut banks, and reinforce banks to prevent sloughing. We used sandbags filled with spawning size gravel. Bags that broke or deteriorated contributed spawning gravel to the stream instead of fine sediment. Impacts to the riparian area were minimized by utilizing distinct pathways covered with bark chips.

Power was not available at our remote location. We initially used 12 volt deep draw batteries that required constant recharging in the shop and transport, or onsite charging with a generator. Because numerous power outages were experienced with this method, we decided to try alternative sources of energy. A hydro generator (basically a propeller) was used in 1998 and worked early in the spring during high flows. However, this was not sufficient as the water level and current velocity dropped below the minimum current velocity of $1 \mathrm{~m}^{3} / \mathrm{second}$ required to produce a charge to the batteries. Batteries are now being charged on-site using three 75 watt solar panels. On a sunny day, charge rates above 14 amps per hour have been seen. It takes about three days of rain and overcast skies before the batteries need to be recharged using the generator. An entire season with no battery change required has occurred. Initially several 12 volt batteries in parallel were used to power the system. We have since changed to two 6 volt golf cart batteries in series to provide more amperage.

Red LED lights were chosen to provide nighttime lighting in the counting chamber. Infrared lighting has been advocated, it dissipates rapidly in water and we have not used it. White light was not used because of the amperage draw of 5 amps per hour compared to $1 / 2$ amp per hour for the red LEDs, and to eliminate possible fish avoidance of white light. In 1997 and 1998, two LED light arrays were mounted beside the camera approximately four to five feet from the fish passage zone. Since 1999, LED arrays have been attached on the inside of the Plexiglas viewing window, facing the back plate, for better illumination of the counting chamber. Lights can be positioned on the bottom, middle and top of the counting chamber at the entrance and exit. However, four light arrays two each at the top and bottom positions are now used at high water levels. The top two lights are removed when the water level recedes below them. This provides much better viewing and appears to be a requirement for operation of the automatic editing system.

Initially, T-120 8mm videotapes were used with the $8 \mathrm{~mm}$ time-lapse recorders. A videotape lasted about 30 hours at 2 frames per second. The $8 \mathrm{~mm}$ recorders were 
replaced by VHS recorders in 2002. We now use T-160 VHS videotapes capable of recording about 32 hours of information in the extended play mode at 4.5 frames per second. Both systems were reliable, although VHS videotapes were less expensive and provided more frames of fish passage. Videotapes were taken immediately to the office where they were manually reviewed for proper operation and the data was recorded. With both Lake Creek and the Secesh River fish counting stations in operation, the manual review process was too time consuming and review of one station's videotapes would gradually fall behind. However, both videotapes were checked to ensure lights were operating at night and both recorders were operating properly. Malfunctions could then be quickly corrected.

The computerized editing system for video monitoring of fish passage described in Hatch et al. (1998) did not work again for our system in 2002. Lighting in the counting chamber must be kept as even and constant as possible and it has been a constant struggle to provide bright, even lighting at night and to prevent bright uneven lighting during the day in our setup. Because the editing system is triggered by a change in contrast of the background, as when a fish passes in front of the white panel background, any physical changes in light intensity will trigger the system. Early in the season, high flows caused turbulence and bubbles to trigger the system. Although this was prevented by floating a piece of plywood on the surface in the counting station, salmon used this as cover and stayed in the counting chamber for excessive times, thus defeating the purpose of the editing system. In addition, at low sun angles, rippling shafts of bright sunlight entered the counting chamber and triggered the system. The entire counting chamber area is now covered by parachute rip stop nylon that diffuses areas of bright light. Daum (USFWS Fairbanks, personal communication) has used clear Lexan® to cover the fish passage area.

Fish lengths have been determined by measuring the fish against a $10 \mathrm{~cm}$ grid system that was marked on the bottom and back plates of the counting chamber. This involved interpretation. Fish appeared larger by obscuring more grid marks the closer they were to the camera. Trying to project a line from the fish's nose and tail to the bottom grid marks became more difficult as fish moved up from the bottom plate. There was a difference in fish length determinations between readers. The resulting $\pm 10 \mathrm{~cm}$ accuracy was unsatisfactory. In 2000, lasers were purchased to determine lengths using proportions. These lasers produced a dot. Most fish swam above, below, right or left of the laser dots. One of the lasers was not waterproof and malfunctioned. In 2001, we purchased a better quality underwater laser with line generating optics. When mounted, these produced two parallel lines over an 80 degree arc. Using proportions, fish lengths could be calculated. Shortly after installing the line generating lasers, the lines started randomly changing in width from thin to broad (Figures 10 and 11) and results were not consistently reliable. The problem was corrected after the 2001 season. In 2002, the line generating lasers operated properly and fish lengths were determined using proportions. We expect fish lengths determined by lasers to be negatively biased. A true length measurement would require the fish to be perfectly perpendicular to the camera and lasers. Curves in the fish's body as it swims or fish swimming toward or away from the camera would result in a shorter fish presented to the camera and a shorter calculated fish length. If possible, 
three lengths (from different video frames ) were calculated for each fish. To minimize the negative bias due to fish curvature, the longest calculated fish length was used No fish were captured to validate the accuracy. The NMFS Section 10 permit for this project does not have a "take" provision and fish can not be captured for measurement.

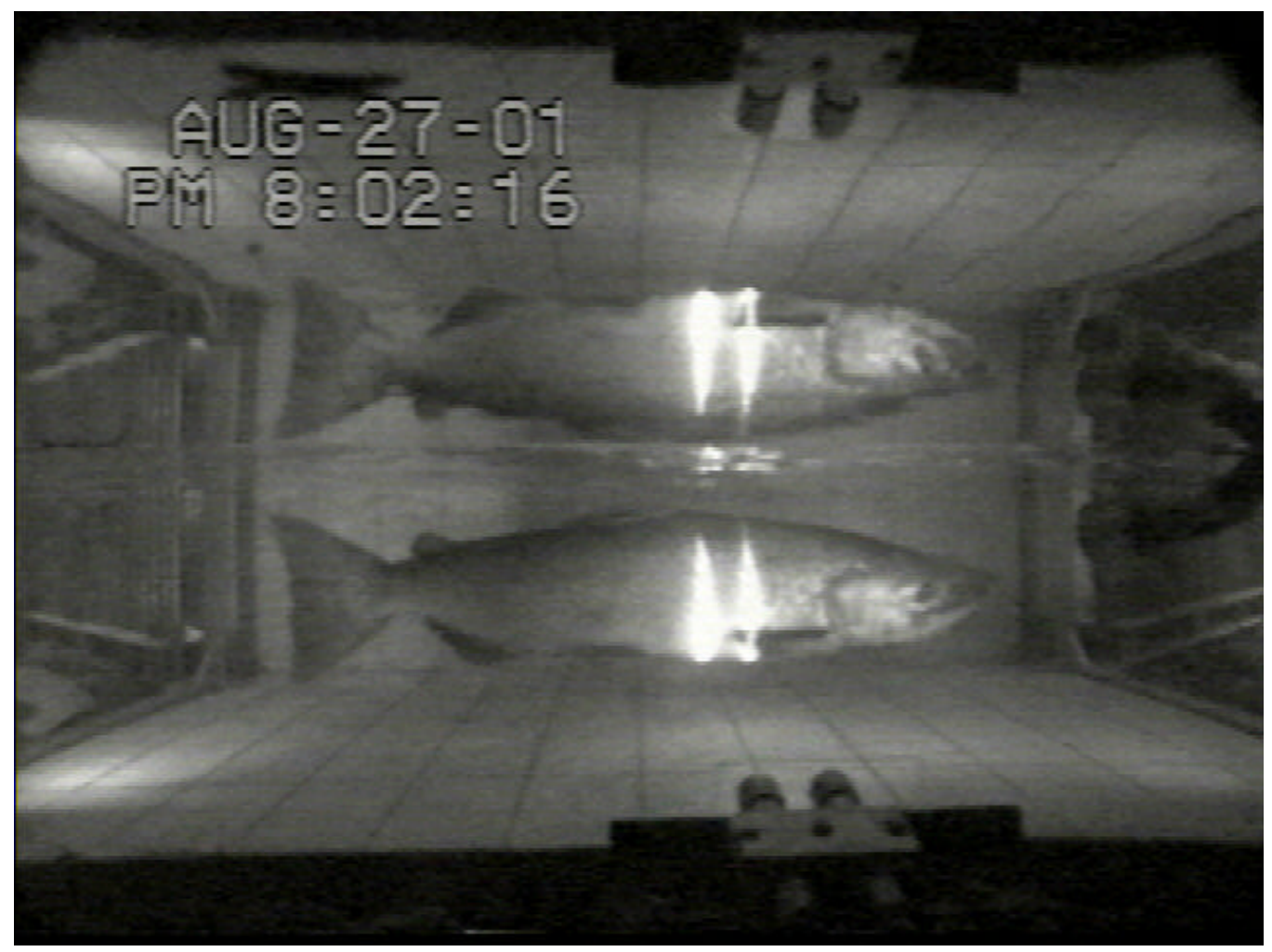

Figure 11. Adult chinook salmon with wide laser lines. Upside down image is a reflection from the water surface.

\section{ABUNDANCE}

The Lake Creek fish counting station was installed on June 11, 2002 after peak spring runoff, and operation began immediately (Table 1). Adult chinook salmon spawner abundance in Lake Creek was 410 fish \pm 4 fish (95\% C.I.) (Figure 12). The underwater video camera photographed 408 of the adult spawners in 2002. Videotape reader efficiency was $100 \%$ and no correction was necessary. A correction for periods of downtime (Appendix Table A-4) added two fish \pm 4.47 to the total adult abundance for 2002. Adult salmon spawner abundance has varied dramatically from 1998 to 2002, ranging from 51 fish to 697 salmon (Figure 12); a two to eight fold range in abundance. The number of salmon above the fish counting station decreased slightly at the end of the season as dying fish drifted out of the system. When operations ceased on September 11, a minimum of 396 salmon remained upstream of the fish counting station.

Hatchery fish comprised $7.4 \%$ of the spawner abundance (Table 2), or 30 adipose clipped fish. Theses hatchery adults were assumed to be from the McCall Fish Hatchery. 
Table 1. Summary of major chinook salmon escapement dates in Lake Creek, 1998 to 2002.

\begin{tabular}{|c|c|c|c|c|c|}
\hline Activity & 1998 & 1999 & 2000 & 2001 & 2002 \\
\hline Installation & 22 June & 9 July & 22 June & 21 May & 11 June \\
\hline First fish & 8 July & 11 July & Prior to 22 June & 9 June & 26 June \\
\hline Peak net upstream movement & 18 July (6) & 20 July (14) & 27 June (27) & 22 June (54) & 8 July (41) \\
\hline Median net upstream passage & 18 July & 21 July & Undetermined & 29 June & 8 July \\
\hline Peak of activity & 6 August (29) & 19 August (34) & 7 August (113) & 22 June (54) & 18 August (57) \\
\hline Last fish & 26 August & 3 September & 31 August & 6 September & 2 September \\
\hline Operation ceased & 15 September & 13 September & 12 September & 14 September & 11 September \\
\hline Number of fish passages & 221 & 418 & 1,294 & 1,828 & 1,338 \\
\hline Escapement & 51 & 86 & $>325$ & 697 & 410 \\
\hline
\end{tabular}




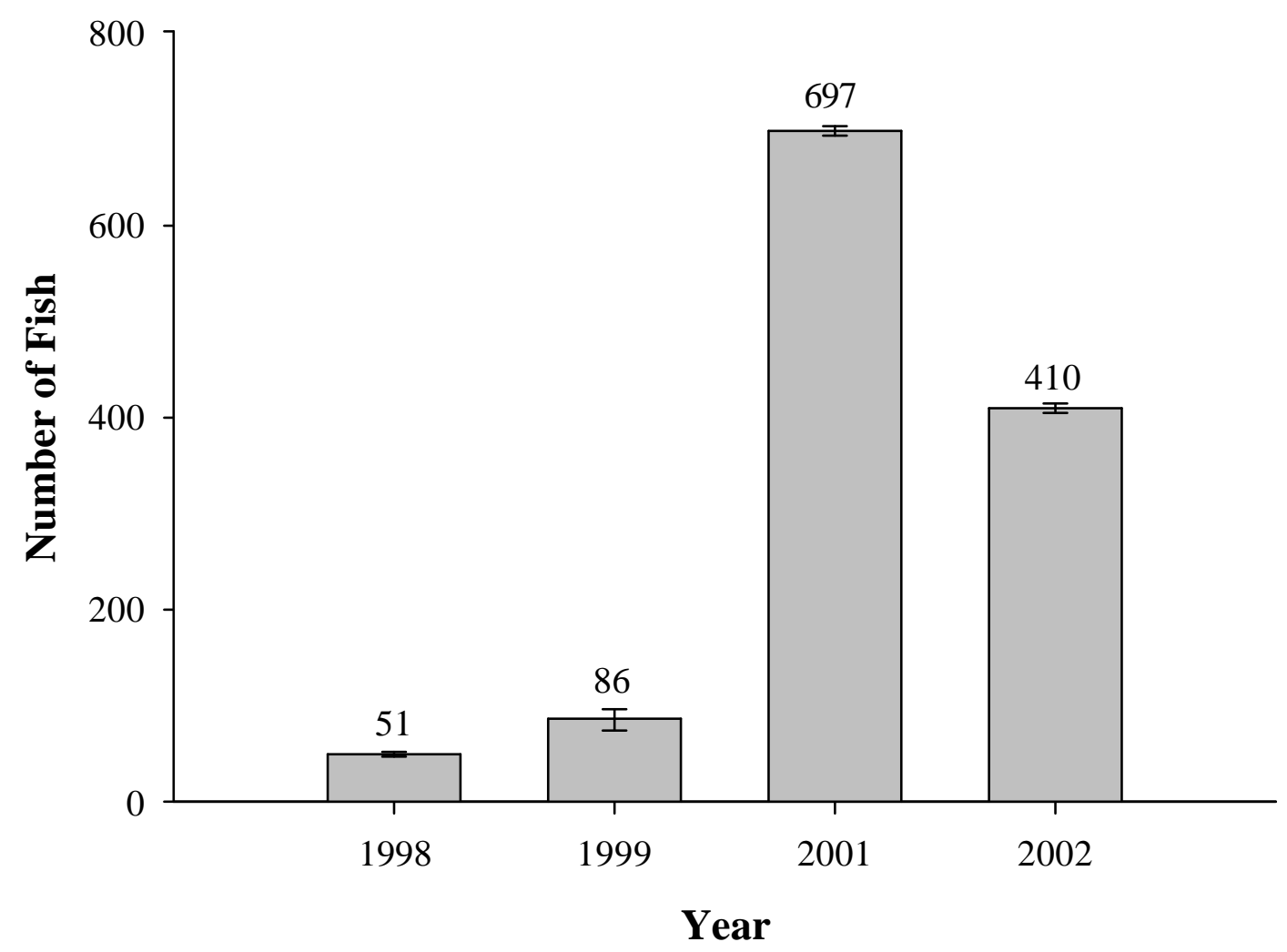

Figure 12. Adult chinook salmon abundance in Lake Creek, Idaho, 1998, 1999, 2001 and 2002. Vertical bars represent $95 \%$ confidence intervals.

\section{POTENTIAL SOURCE OF ERRORS IN UNDERW ATER VIDEO MONITORING}

All sources of error were minimal in 2002. Potential sources of errors in determination of spawner abundance by the underwater video methodology are listed in Table 2 and are described in Faurot et al. (2000). Corrections were made for turbidity, equipment downtime and videotape reader efficiency (missed passages). A total of 2 fish $(0.5 \%)$ were estimated to have passed the Lake Creek fish counting station during downtime (Appendix Table A-4) in 2002. Video recording was 98\% operational (44.5 hours of downtime) while the fish counting station was in place. A tape-viewer-efficiency was determined for passages missed by the observer. Net escapement observed by the readers was compared to net escapement determined by multiple readings of one videotape per week, until agreement among readers was reached. The tape reader correctly observed $100 \%$ of the actual adult net escapement. No correction was made to the observed total net escapement. It was felt that no fish passed undetected before installation, around the ends or under the fish guiding fences. 
Table 2. Potential sources of error in video abundance estimation methodology in Lake Creek in 2002.

Fish passed before installation

Fish escaped under the pickets or counting station Fish escaped around the ends of the fish guiding fences

Fish passed during high turbidity and periods of downtime

Tape observers missed fish passages
None

None

None

Corrected

None

\section{BIOLOGICAL CHARACTERISTICS}

The adult spring and summer chinook salmon count over Lower Granite Dam in 2002 was 97,184 fish. Of these, 37,696 were estimated to be wild fish. Of those, 34,144 were spring chinook, the largest spring chinook return since this data started being recorded in 1979. Escapement into Lake Creek represented approximately $1.1 \%$ of the wild run over Lower Granite Dam (Table 3). About 28 (6.9\%) of the spawner escapement in 2002 were jacks. In 2001 there were 65 jacks (10.0\%). This was the largest number of jacks observed in Lake Creek during the operation of the project (Table 4); however, the 18 jacks that migrated in 1999 represented a larger proportion (26.9\%) of the spawning population.

Table 3. Percent of wild adult spring and summer chinook salmon counted over Lower Granite Dam that spawned in Lake Creek and the Secesh River watershed, in 1998 to 2002 (TAC Biological Assessment Tables, corrected).

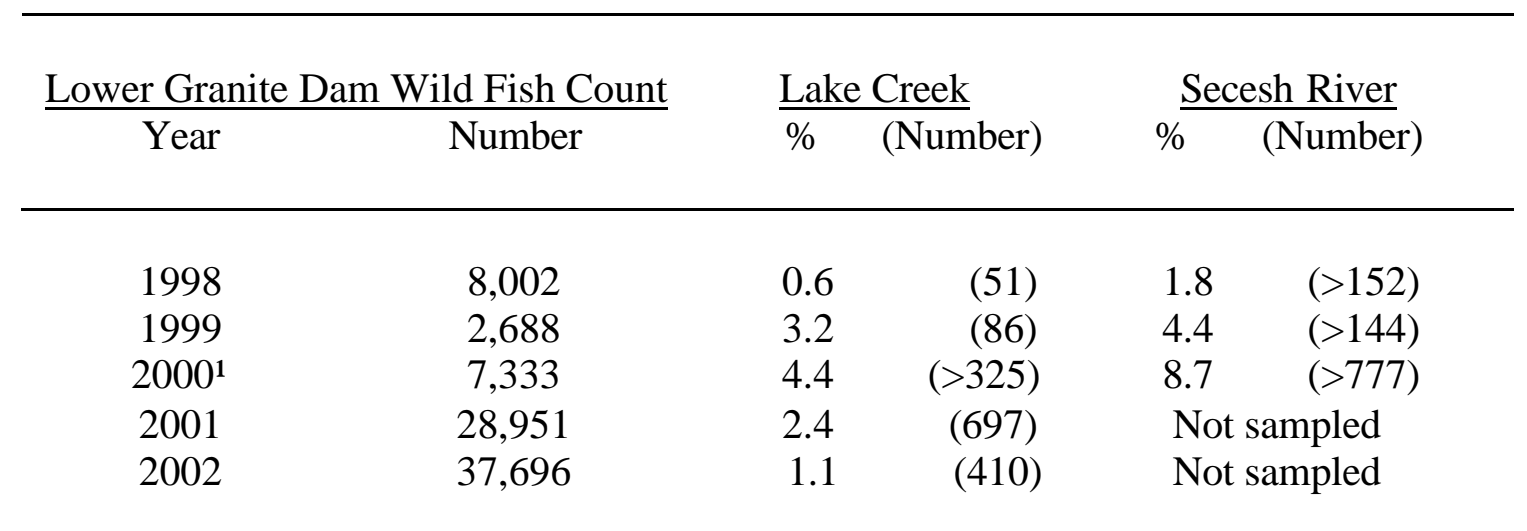

\footnotetext{
${ }^{1}$ Incomplete sampling year
} 
Table 4. Number and proportion of chinook salmon jacks in the Lake Creek spawning migration 1998 to 2002.

\begin{tabular}{cccc}
\hline Year & Escapement Videotaped & $\begin{array}{c}\text { Number of Jacks } \\
\text { Observed }\end{array}$ & $\begin{array}{c}\text { Proportion of Jacks in Run } \\
(\%)\end{array}$ \\
\hline 1998 & 51 & 0 & 0 \\
1999 & 67 & 18 & 26.9 \\
$2000^{1}$ & 293 & 27 & 9.2 \\
2001 & 648 & 65 & 10.0 \\
2002 & 408 & 28 & 6.9 \\
\hline
\end{tabular}

${ }^{1}$ Incomplete sampling year

\section{MIGRATION TIMING}

The Lake Creek fish counting station was installed immediately after peak spring runoff, in 2002, in an attempt to ensure early operation of the facility. Installation of the structure occurred on June 11 and operation began immediately. The first spring/summer chinook salmon had passed over Lower Granite Dam on March 20. The first upstream migrating adult salmon passed the Lake Creek site on June 26, 15 days after the initiation of underwater videotaping (Table 1). This period of no fish passage leads to the conclusion that video coverage of the first fish passage of the adult salmon spawning migration occurred in 2002.

The first fish in 2002 was observed on June 26 (Table 1). The first fish arrived on July 9 in 1998, July 11 in 1999, prior to June 22 in 2000 and June 9, 2001. Net escapement increased slowly the first week of the migration (June 26-30) and increased rapidly the next two weeks (July 1-15) (Figure 13). Net escapement increased slowly until August 15 , when fish started dying and drifting out of the system. Peak of net upstream migration occurred on July 8, 12 days after the arrival of the first fish. The single day peak of net escapement occurred on July 8, when a net of 41 chinook salmon passed upstream through the fish counting station (Figure 13, Table 1). The total maximum net escapement for the season occurred on August 19, when 410 chinook salmon had migrated upstream through the Lake Creek fish counting station (Appendix Table A-1). The height of adult chinook salmon spawning in Lake Creek in 2002 occurred between August 6 and 22 (NPT, unpublished data). Arrival of the first fish, the median passage and the peak of net upstream movement, in 1998 and 1999, were all within two to three days of each other (Table 1). Snow pack in the springs of 1998 (72\% of normal) and 1999 (148\% of normal) represented substantially different runoff years. Data from those two years of operation had led us to believe the run timing of the Lake Creek spawning 


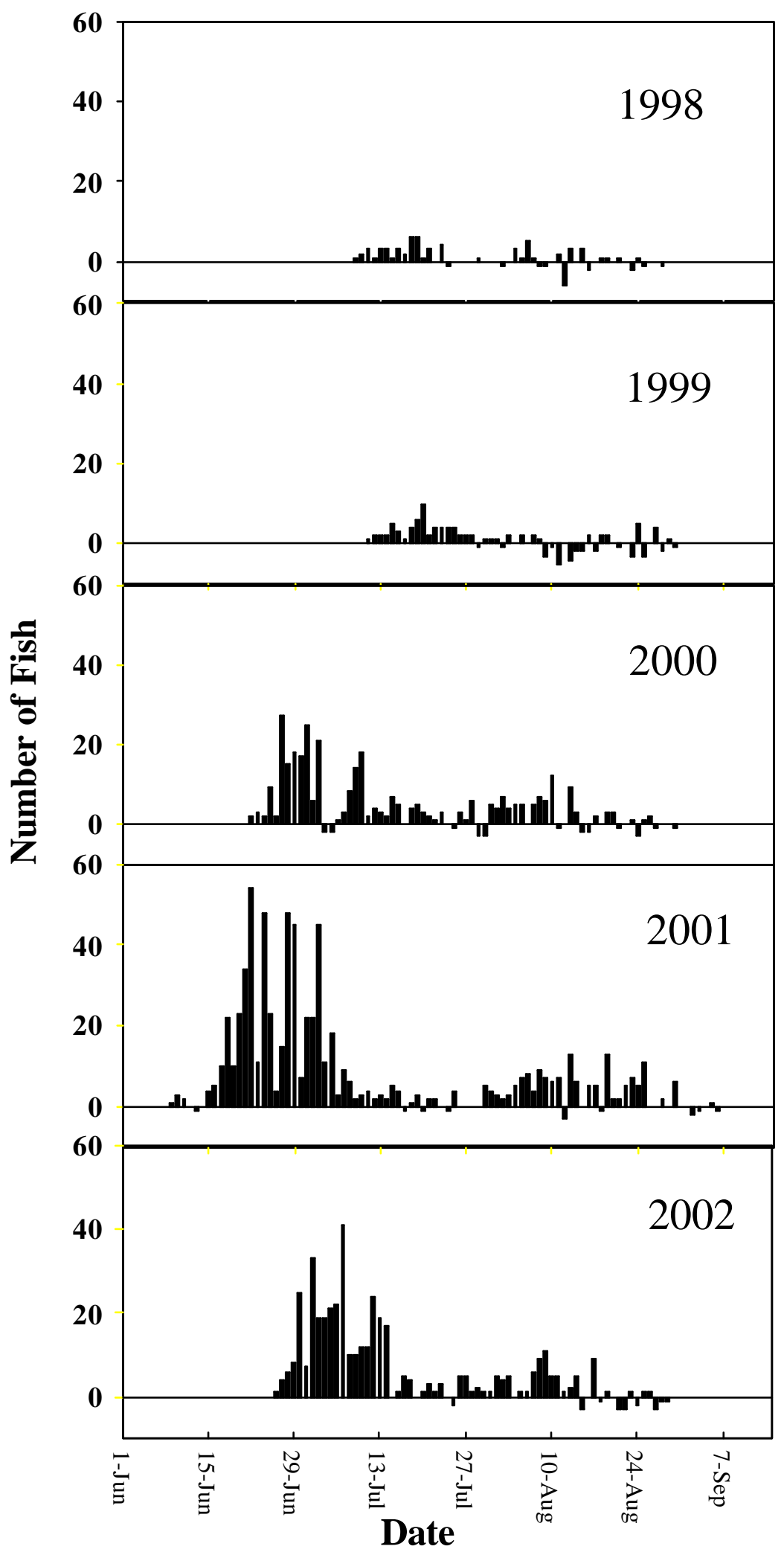

Figure 13. Net upstream spawning migration of adult spring and summer chinook salmon migrating through the Lake Creek fish counting station from 1998 to 2002. 


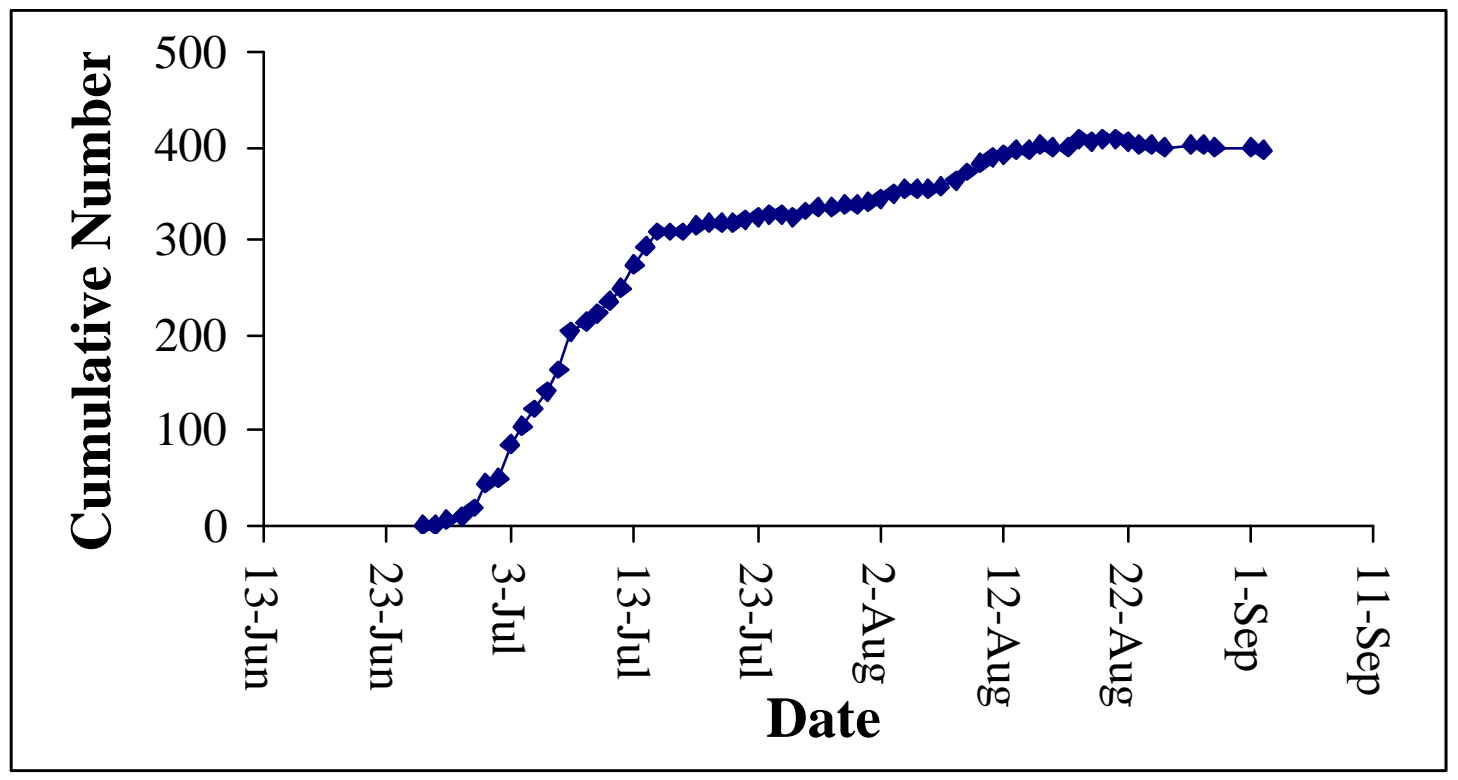

Figure 14. Cumulative observed adult spring and summer chinook salmon spawner escapement at the Lake Creek fish counting station in 2002.

aggregate was fairly rigid. However, results from 2000, 2001 and 2002 indicated that salmon migration timing in natural production areas can vary as much as four weeks. In 2002, as in 2000 and 2001, the date of median passage and peak of net upstream movement occurred earlier than the date of the first fish arrival in 1998 and 1999. Net escapement into Lake Creek increased throughout the season in 2000, 2001 and 2002. In 1998 and especially 1999, net escapement decreased during the second segment of the run (Figure 13).

We suggested this decrease in net escapement in 1998 and 1999 was attributed to males that had spawned in Lake Creek and were dropping downstream to mate with later spawning Secesh River fish. There was a large component of jacks and a small component of females in 1999 that might have contributed to this movement.

In Lake Creek in 2002, as in 1998 through 2001, there appeared to be two behaviorally distinct segments to the spawning migration (Figures 13 and 15). Rapid upstream migratory movement of both sexes characterized the first segment (June 11 to July 15, 2002). Increased upstream and downstream movement of males which appeared to be associated with spawning activity characterized the second segment. This behavior (increased total activity) is illustrated in Figure 15 and Appendix Table A-3. In 2002, the separation between the two segments occurred from July 20 to 29 (Figures 13, 15 and Table 5). In spite of the increased downstream movement, net escapement continued to increase slightly during the second segment (Figure 13, 14 and 15). 


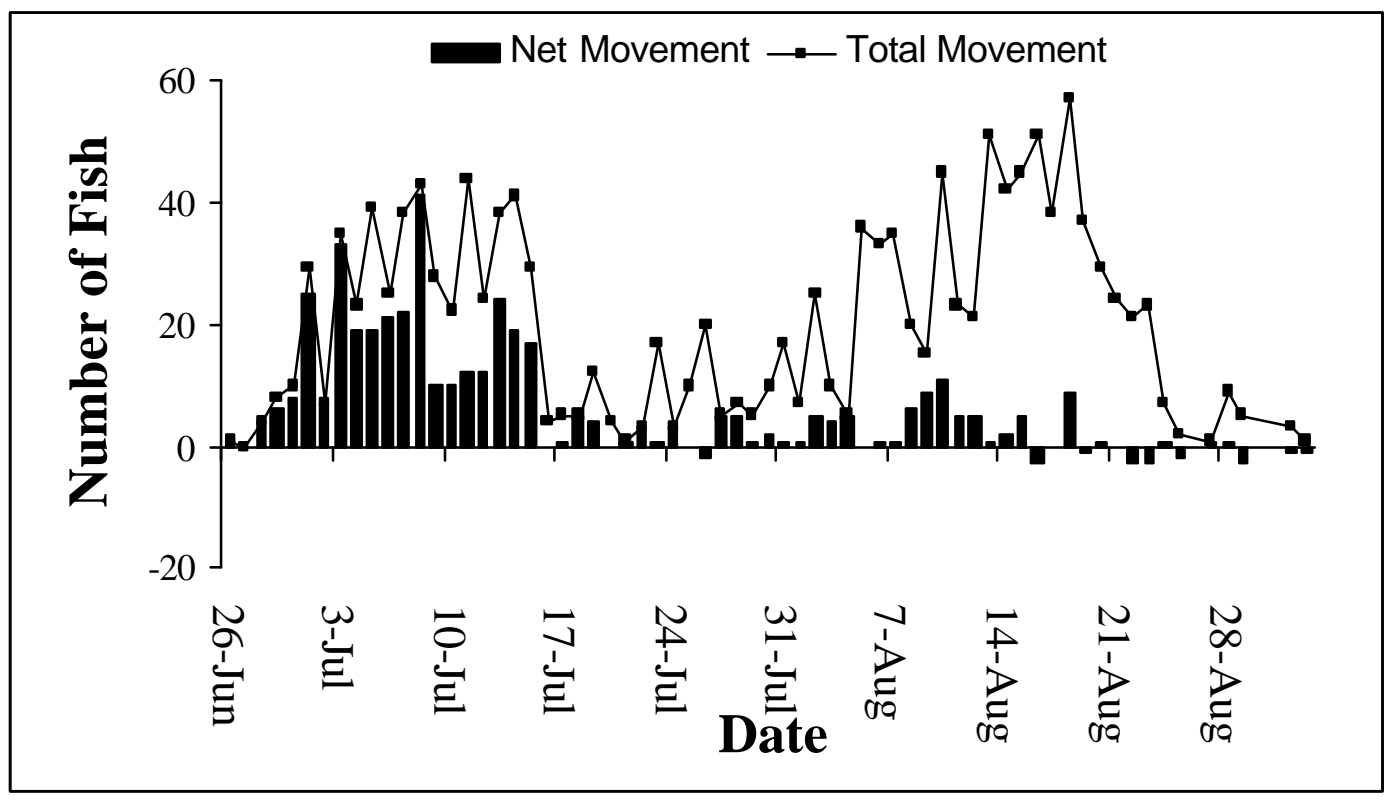

Figure 15. Daily net upstream and total movements of adult spring and summer chinook salmon through the Lake Creek fish counting station in 2002.

Table 5. Approximate dates of change between the first and second segments of the chinook salmon spawning migration in Lake Creek and the Secesh River, 1998 to 2002.

Year Lake Creek Secesh River

1998

1999

2000

July 25 - August 4

July 29 August 5

2001

July 30- August 6

July 30 - August 6

2002

July 11 - July 28

July 20 - July 29

July 6 - July 30

July 20 - July 29

1

1

${ }^{1}$ not sampled.

\section{Diel Movement}

Diel migration information of the salmon spawner migration was obtained from the videotapes. Although total activity (upstream plus downstream movements) at the Lake Creek site in 2002 was lowest between 7:00 a.m. and 3:00 p.m. (Figure 16, Appendix Table A-2), there was no difference in the amount of total activity between daylight and darkness. This compares with results from previous years. From 1998 to 2002, 45-59\% of the total movement occurred during darkness. Later in the season, males dominated most of the observed movement. 


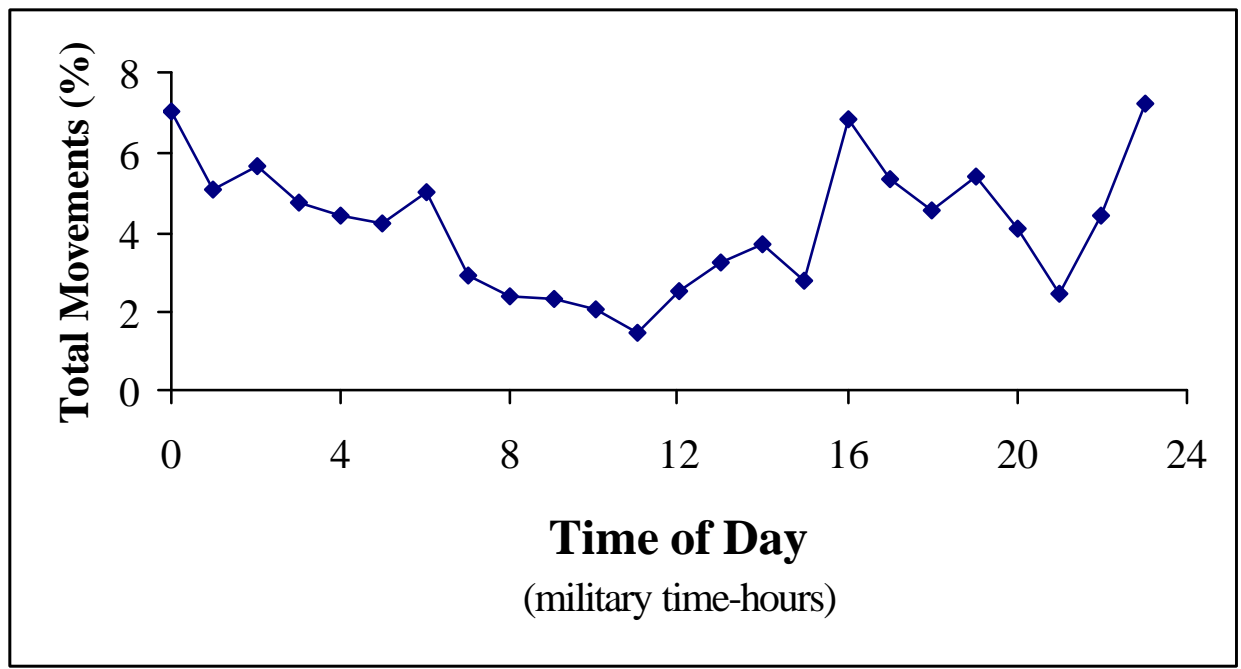

Figure 16. Diel timing of total activity (upstream plus downstream movements) of adult spring and summer chinook salmon through the Lake Creek fish counting station in 2002.

In 2002, net upstream migration (upstream minus downstream movements) past the Lake Creek site also varied little between day and night (Figure 17, Appendix Table A-2), with $41 \%$ of the net upstream movement occurring during darkness (9:00 p.m. to 6:00 a.m.). The amount of nighttime movement has varied, particularly in 1998 when $94 \%$ of the net upstream movement occurred in darkness. From 1998 to 2002, 39-94\% of the net upstream movement occurred between 9:00 p.m. and 6:00 a.m. Net upstream movement in 2002, appeared to be lowest from 1:00 a.m. to 3:00 p.m. (Figure 17).

Fish counters at main stem Columbia River and lower Snake River dams have typically discontinued counting anadromous adults at night between 9:00 p.m. and 5:00 a.m. because of low passage rates. Because fish passageways at dams are upstream only, dam passage information is comparable to upstream only migration at the fish counting station. Hatch et al. (1994a) monitored the migration of adult sockeye (O. nerka) and chinook salmon at the fish-viewing window at Tumwater Dam on the Wenatchee River in Washington using a time-lapse video recorder system. They found nighttime upstream migration past the dam (between 10:00 p.m. and 4:00 a.m.) to be from 6.7 to 16.2 percent of the daily passage. At Lower Granite Dam on the main stem Snake River, Hatch et al. (1994b) counted 6.4 percent of the fish migrating upstream at nighttime. Calvin (1975) also found low rates of nighttime upstream migration movement at main stem Columbia River dams. The diel timing of spring and summer chinook salmon in this spawning tributary system was quite different than those observed above. In 2002, 33\% of upstream only migration occurred between 10:00 p.m. and 4:00 a.m (Figure 18). From 1998 to $2002,30-46 \%$ of the upstream movement occurred between 10:00 p.m. and 4:00 a.m. it appears that in smaller rivers and streams closer to spawning areas, there is more upstream migration activity between 10:00 p.m. and 4:00 a.m. as compared to migration at dams lower in the system. 


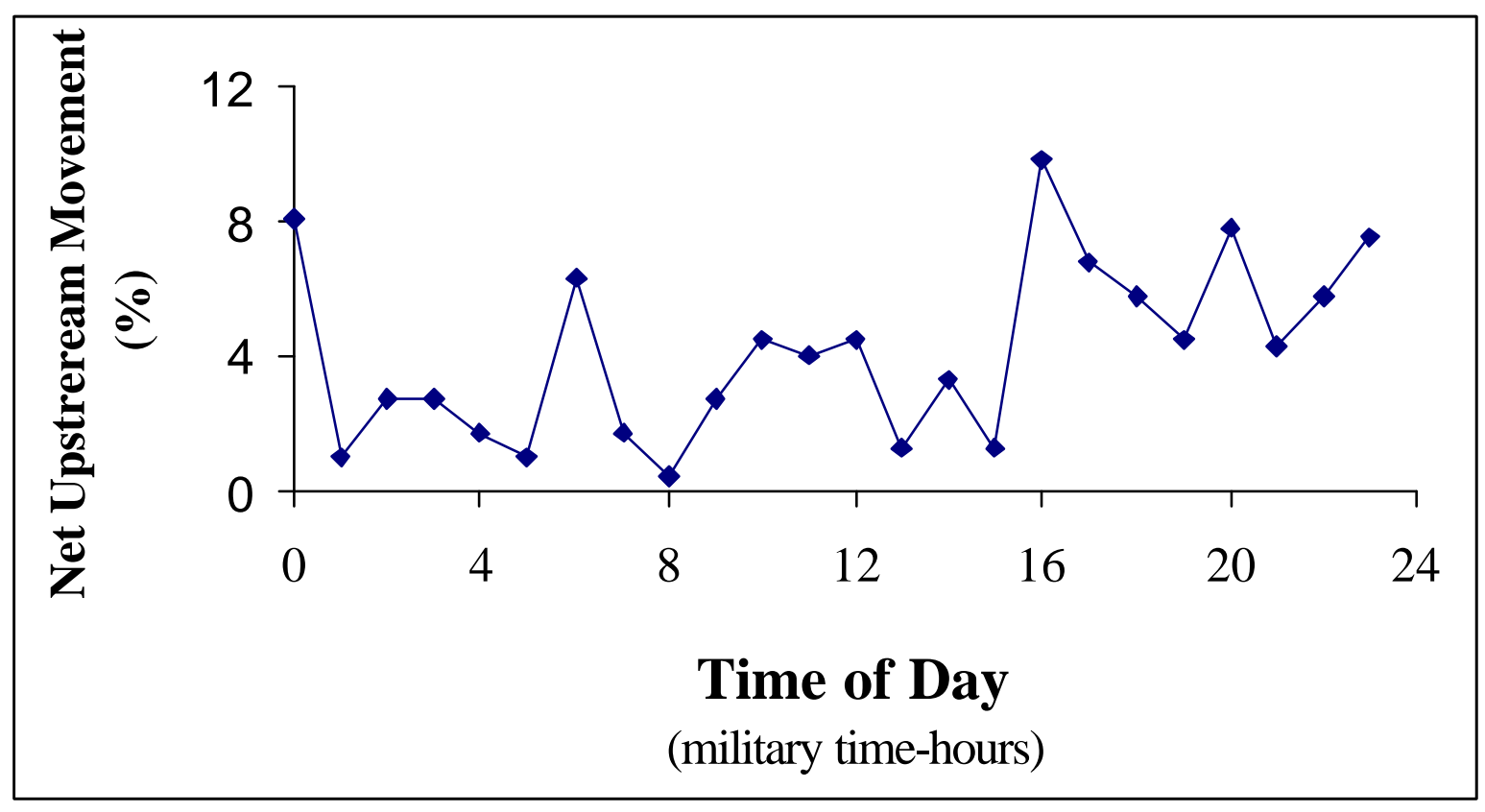

Figure 17. Diel timing of net upstream movement (upstream minus downstream) of adult spring and summer chinook salmon through the Lake Creek fish counting station in 2002.

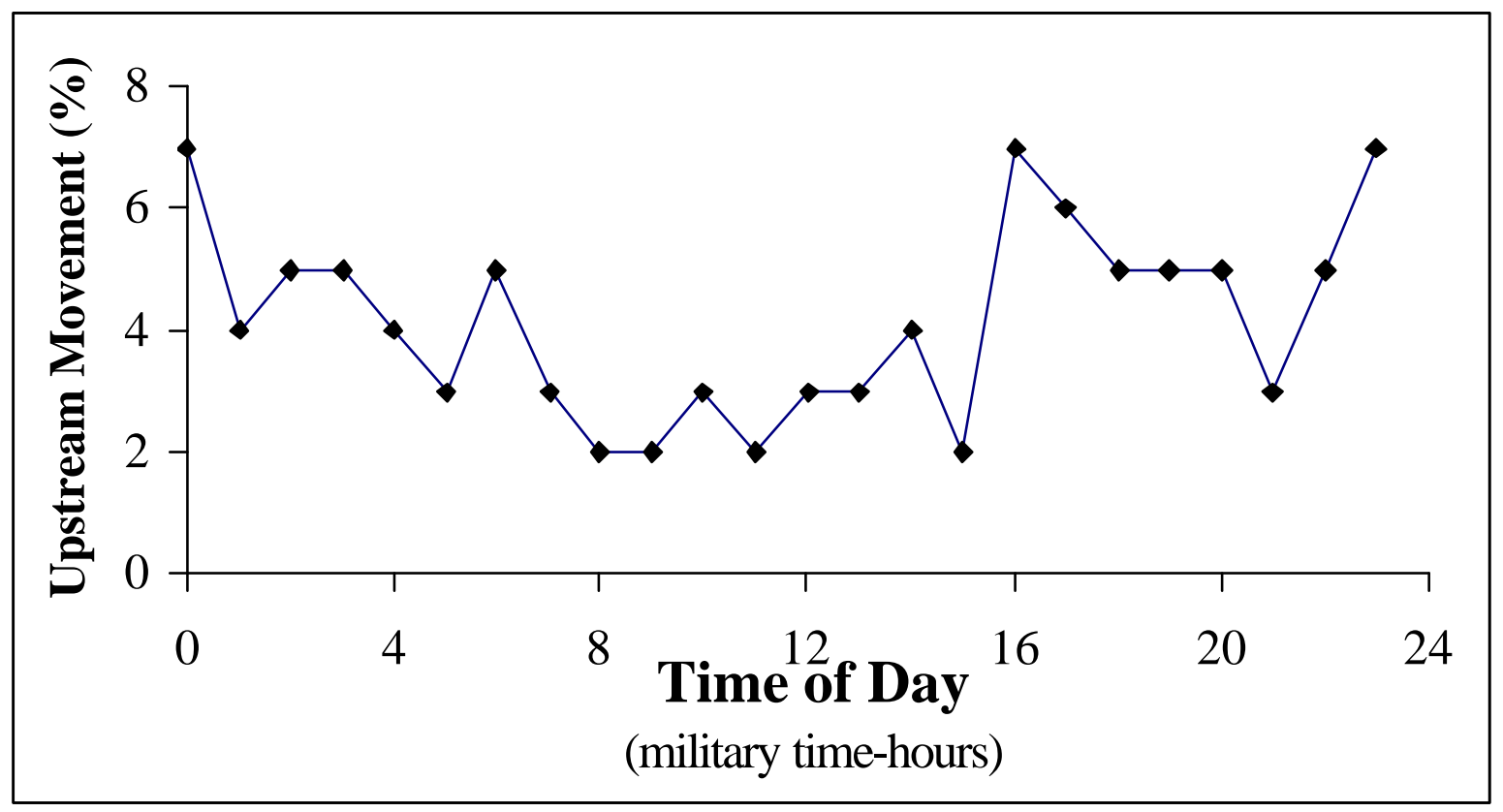

Figure 18. Diel timing of upstream only movement of adult spring and summer chinook salmon through the Lake Creek fish counting station in 2002. 


\section{REDD COUNTS}

Nez Perce Tribe index area (176) and extensive area (200) redd counts (NPT unpublished data) in Lake Creek in 2002 were approximately double the long-term average of 100 redds in the index area (IDFG unpublished data). The 296 redds counted in the index area in 2001 were the highest recorded since data collection began in 1957 (ElmsCockrum 1999, IDFG unpublished data). Redd counts provide an index of relative abundance, trend information and spawner distribution information. Redd counts are less time consuming and less expensive than alternate methods. The most commonly used measure is the index area redd count where redds are counted in the same fixed (index) area each year. IDFG conducts a single pass redd count, at the peak of spawning, for this trend information. Typically, managers expanded single pass index area redd counts to estimate salmon spawner abundance. This provided a good relative abundance because this time series of information extended back into the mid 1950's. However, "Index redd counts conducted by the IDFG are used for trend information, not escapement estimates" (S. Keifer et al. 1996). Ortmann (1966) reported: "Redd counts.... while providing our best yearly trend information, introduce considerable positive bias when used to estimate the number of fish in an escapement, and should be recognized as trend indicators only". There are limits to the use of redds to detect a change in trend. Using power analysis, Maxwell (1999) found the power of detecting changes in bull trout population size remained low throughout the first 15 years of monitoring unless the decline or increase was as high as $50 \%$ per generation. If declines were small and steady, populations could decline by more than $47 \%$ before the decline was detected. The Nez Perce Tribe, and others, conduct multiple-pass redd counts that account for the annual variation in spawning timing. Multiple-pass redd counts are usually conducted three to five times over the course of the spawning period. This comprehensive survey is thought to be more accurate. Additional abundance data can be obtained using extensive area redd counts that attempt to count redds in a larger area that encompasses all available spawning habitat in a tributary and provide more comprehensive redd count data. In general, redd counts have provided valuable long-term population trend information and biological data from carcasses over time.

Salmon redd count information is subject to a variety of potential unquantified sources of error. Redd count measurement is not an exact science. The basic source of redd count measurement error is observer error. Variation in redd size, age, density, superimposition, water depth, turbidity, angle of the sun, stream hydraulics, substrate composition and many other factors may affect the identification of redds. Redd counts are affected by the experience, or lack of experience of the observer. Counts conducted from the ground are usually more accurate than those from a boat or an airplane. The IDFG single pass count is conducted on the predicted peak date of spawning activity. Spawning activity varies yearly, by environmental conditions. Schwartzberg and Roger (1986) found on the Yakima River, in two of the four years studied, the predicted peak date of spawning did not coincide with or even closely follow the true peak of spawning activity and redd deposition. The timing of redd counts may lead to errors if redds are formed after counting or, if redds constructed before counts are conducted become 
obscured before counting (Dunham et al. 2001). Both of these will underestimate the number of redds.

Females are known to dig multiple redds (McCart 1969, IDFG unpublished data), and do not always complete redds (test digs). The number of redds counted in a tributary depends on the size of the area surveyed. Index areas are fixed in size while extensive area surveys can vary from year to year depending on the time available. Dunham et al. (2001) found observer redd counts within a fixed area ranged between 28 and $254 \%$ of the best estimates of bull trout redd numbers. We compared IDFG (aerial) and NPT (ground) index area redd count results on Johnson Creek from 1987 to 1999 (Figure 19). Even though the slope of the regression was close to 1 which indicated they were similar, annual differences in redd counts ranged from 0 to $100 \%$. The mean difference for all years was $22 \%$. The mean difference in NPT and IDFG redd counts in Big Creek was $23 \%$ and $31 \%$ in Lake Creek.

Redd count measurement errors are compounded and new errors introduced when redd counts are expanded. Chinook salmon index area redd counts, which are part of the larger extensive survey area, are generally less than the extensive survey area count. However, there are exceptions as index area and extensive area survey counts are sometimes conducted by different observers, at different times and by varying methods (aerial and ground, and single-pass and multiple-pass counts). Beamesderfer et al. (1998), Faurot et al. (2000), Roger and Schwartzberg (1986) and Schwartzberg and Roger (1986) all discussed sources of error and variation in spawning ground survey redd counts. By direct video enumeration of chinook salmon spawners, these sources of error are eliminated.

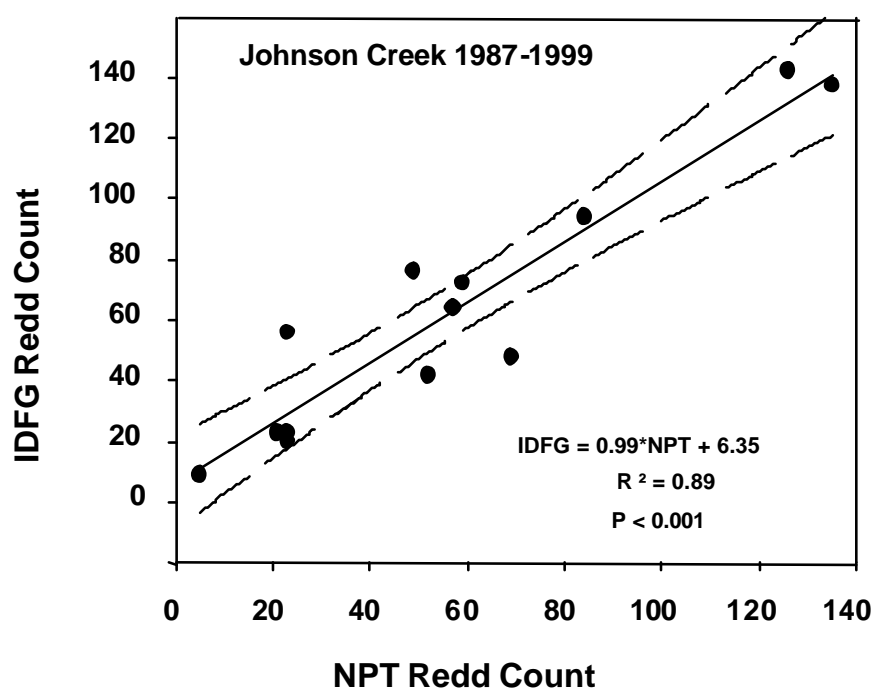

Figure 19. Comparison of Nez Perce Tribe and Idaho Department of Fish and Game redd counts on Johnson Creek, 1987 to 1999. 


\section{ACCURACY OF REDD COUNT EXPANSIONS}

The third objective of this study was to determine the accuracy of redd count expansion methodology compared to the underwater video adult abundance numbers. Reliable and accurate spawner abundance estimates from unsupplemented salmon spawning aggregates are a necessary tool to monitor ESA listed species. Salmon spawner numbers are determined either through a direct measurement of fish numbers (video) or expanding redd counts by a predetermined factor (redd count expansion). Abundance information is used to determine population status and determine if a stock can sustain a fishery. Actual abundance is used with other information to provide accurate fish per redd numbers, spawner to spawner ratios, recruits per spawner and population growth rates. Redd count surveys count redds (not fish) and provide an index of relative abundance, trend information and spawner distribution over time. Each method must stand on its own merits. The methods should be scrutinized based on their intended purpose, advantages and disadvantages, so that managers better understand what they base decisions upon.

Fish abundance is calculated from redd counts by expanding the number of redds by a fish per redd estimate to determine a point estimate of abundance. Fish per redd numbers have been developed at several instream fish weirs throughout the Columbia River basin using various fish population estimate methods and redd counts from the same area over a period of years. This average fish per redd number is used to expand index area redd counts each year for all tributaries within a subbasin. Fish per redd values vary by year, by stream and method used in the calculation (Table 6). For example, individual year fish per redd values determined on Lake Creek using video obtained abundance and multiple-pass redd counts ranged from 1.02 to 3.58. The average fish per redd value used each year by the PATH process (Beamesderfer et al. 1998) for the South Fork Salmon River is 2.31 fish per redd. The average fish per redd value for the South Fork Salmon River used by the Idaho Salmon Supplementation Studies is 3.2. Fish per redd values on the Imnaha River over 16 years (ODFW unpublished data) ranged from 1.6 to 6.8 fish per redd. Most other studies that have determined fish per redd values have not included as long a time period. However, this information is presented for general informational purposes. Fish per redd data from Lookingglass Creek (ODFW unpublished data) from 1967 to 1971 and 1992 to 1994 varied from 2.0 to $2.9(\mathrm{n}=8)$. Johnson Creek, another stream in the South Fork Salmon River, had fish per redd values ranging from 1.34 to $3.67(n=4)$ between 1998 and 2002. Variation in fish per redd numbers is caused by redd count measurement error, size of the survey area (index or extensive),prespawning mortality, sex composition and age structure. Using regression analysis, mean fish per redd numbers varied from 2.05 to 3.93 among four rivers in the Snake River basin and one river in the mid-Columbia River (Figure 20). Johnson Creek's lowest fish per redd value of 1.34 occurred in 1998, the same year as the Lake Creek lowest fish per redd value. Johnson Creek and Lake Creek had a poor jack return that year. Individual tributary fish per redd values within a subbasin may follow similar trends.

An average annual fish per redd value may average out over the long term, but is likely to be inaccurate in the short term. As seen from these studies, the fish per redd numbers varied by number and stream. The fish per redd number is also affected by the size of the survey area and the method of survey. At low population levels, an unbalanced age structure (i.e. no jacks in Lake Creek in 1998) produces a lower fish per redd number and makes an average fish per redd number less reliable. The 3- and 5- year check points required by the NMFS (2000) Biological Opinion are examples where accurate yearly abundance information is needed. 
Table 6. Fish per redd values in Lake Creek compared to data from the Imnaha River and Lookingglass and Johnson creeks.

$\begin{array}{lll}\text { Location } & \text { Group } \quad \text { Fish/redd }\end{array}$

$\begin{array}{lcc}\text { Lake Creek 1998 } & \text { NPT } & 1.02 \\ \text { Lake Creek 1999 } & \text { NPT } & 3.58 \\ \text { Lake Creek 2001 } & \text { NPT } & 2.07 \\ \text { Lake Creek 2002 } & \text { NPT } & 2.05 \\ \text { Johnson Creek 1998 } & \text { NPT } & 1.38 \\ \text { Johnson Creek 2000 } & \text { NPT } & 3.67 \\ \text { Johnson Creek 2001 } & \text { NPT } & 3.58 \\ \text { Johnson Creek 2002 } & \text { NPT } & 3.31 \\ \text { Imnaha River 1990-94, 1996-981 } & \text { ODFW } & 1.6-6.8 \\ \text { Lookingglass Creek 1967-1971 } & \text { ODFW } & 2.0-2.9\end{array}$

${ }^{1}$ Hatchery influenced system.

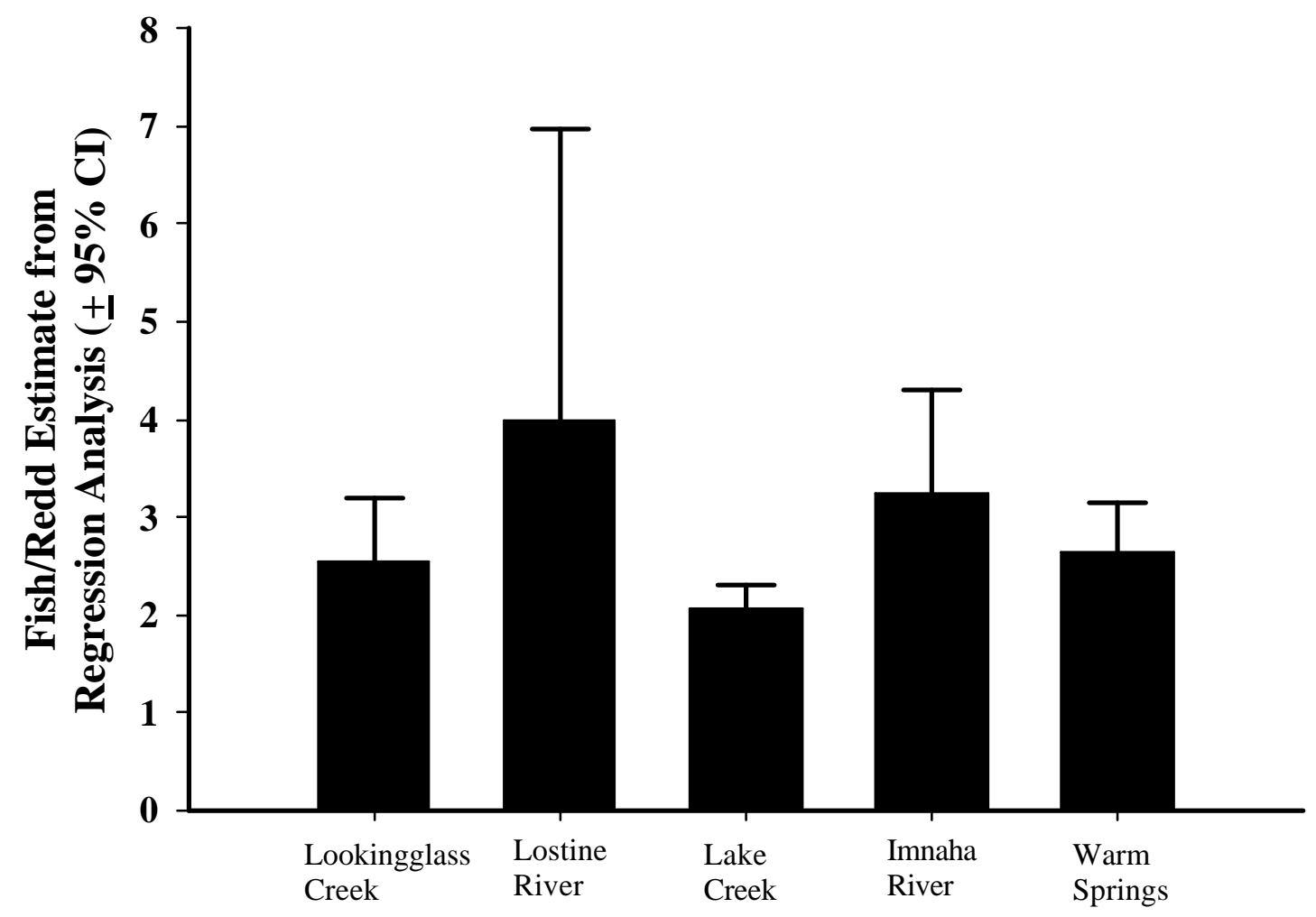

Figure 20. Mean fish per redd estimates based on regression analysis. 
Fish per redd numbers are affected by survey area size. For a given escapement, the fish per redd number for a stream based on an index area redd count should be greater than the fish per redd number for that stream when based on an extensive area redd count. The greater number of redds in a larger extensive survey area would produce a smaller fish per redd number than the fewer redds in the smaller index area. The additional number of redds for the extensive area redd count would depend on the amount of spawning that takes place outside of the index area. As the quality of spawning habitat and spawner distribution changes in a stream due to environmental conditions, the percent of spawning that takes place in the index area will change.

Adult salmon spawner abundance data in Lake Creek for 1998, 1999, 2001 and 2002 was compared to expanded redd count point estimates (index area and larger extensive surveys) to examine the difference from the actual Lake Creek video obtained abundance (Figure 21, Table 7). The average fish per redd values used by PATH (2.31) (Beamesderfer et al. 1998) and ISS (3.2) (Walters et al. 2000) were used for redd count expansion in Lake Creek. These values were calculated for the South Fork Salmon River and represent the range in fish per redd values. The values were then applied to Lake Creek and the point estimates compared to video abundance to determine the most reliable method.

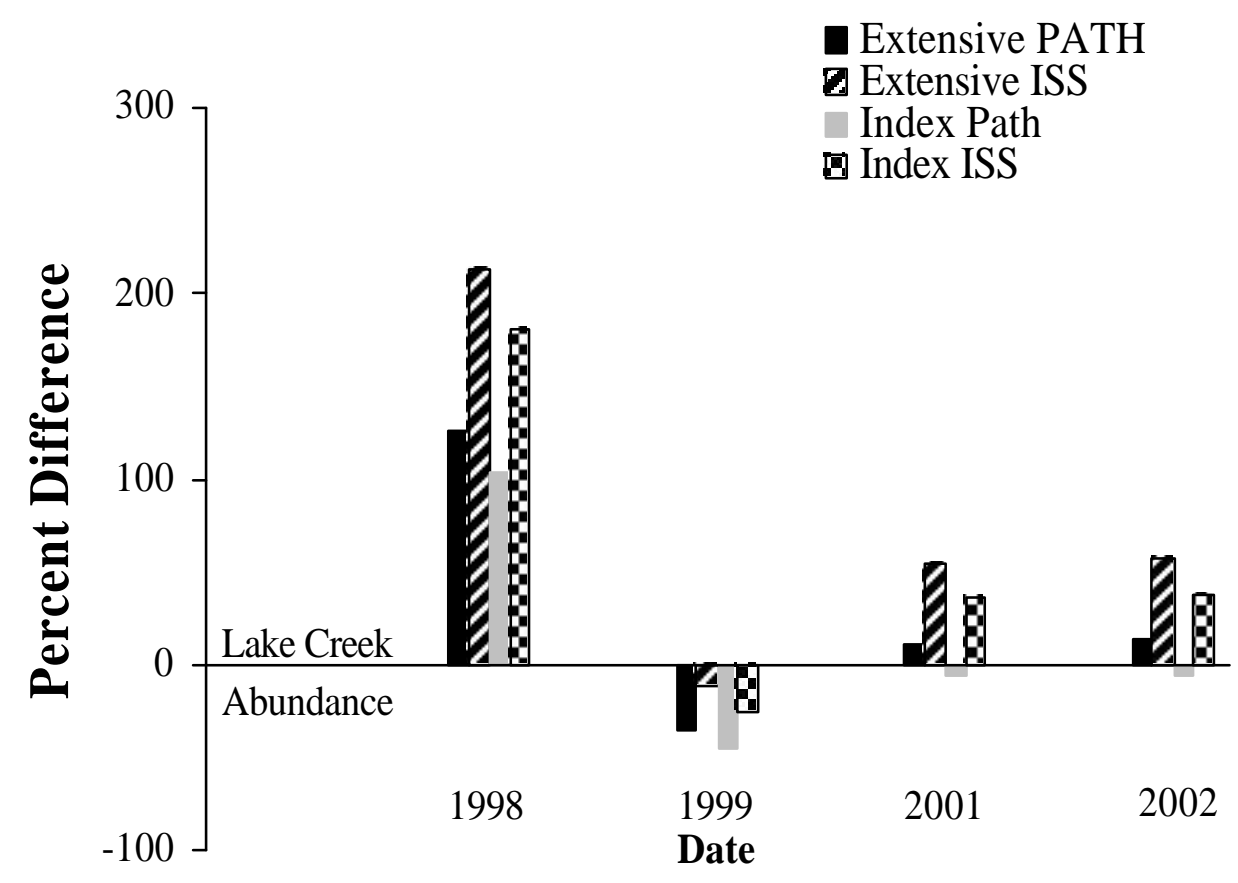

Figure 21. Estimated percent difference of various chinook salmon redd count expansion methods, by year, when compared to Lake Creek spawner abundance estimates in 1998, 1999, 2001 and 2002. 
Table 7. Comparison of video obtained adult spring and summer chinook salmon abundance to expanded redd count estimates in Lake Creek, Idaho, 1998 - 2002.

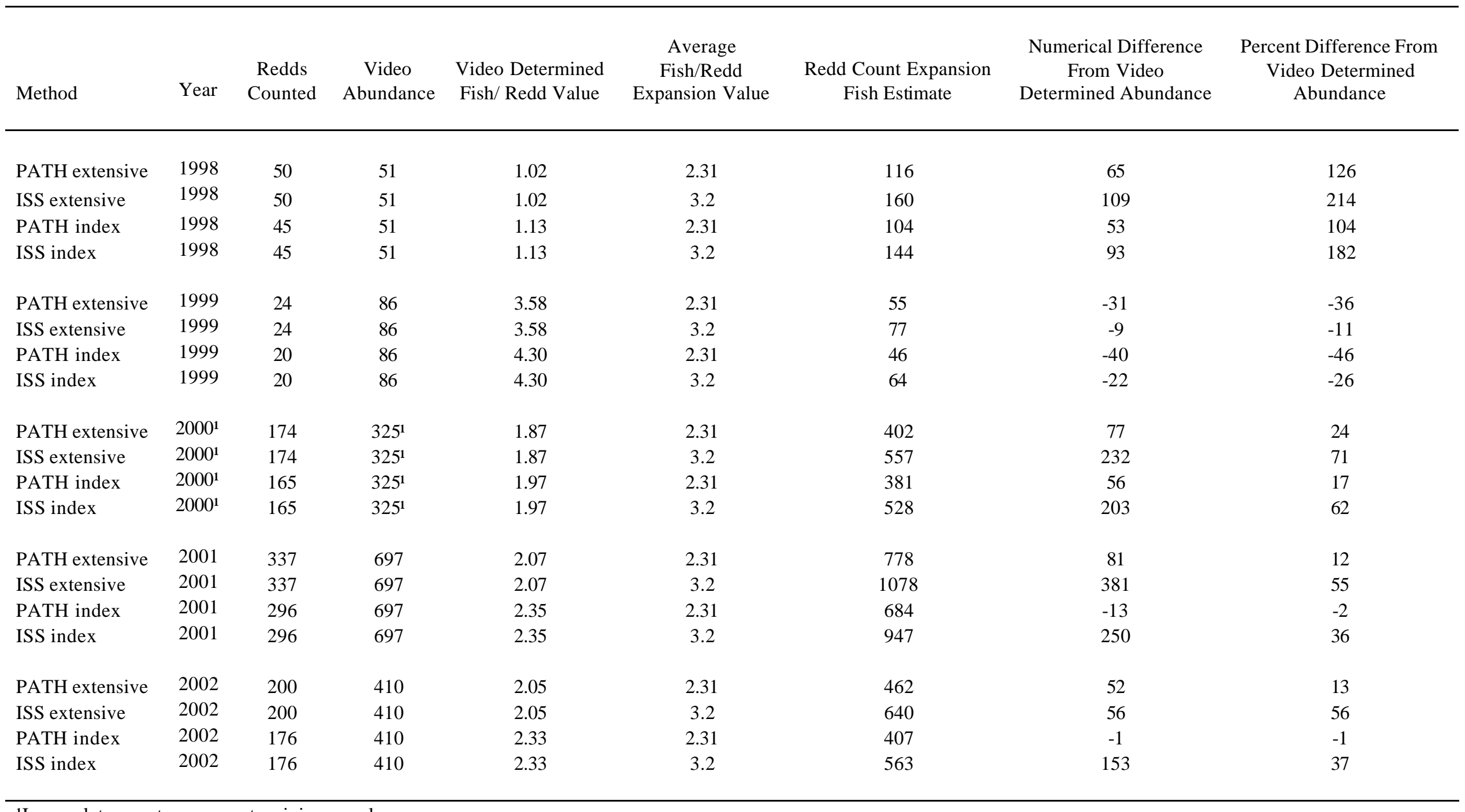

Incomplete count - represents minimum values. 
Extensive survey redd count expansions to estimate spawner abundance were examined first using PATH and ISS fish per redd numbers. Spawners within the extensive redd count area would be expected to most closely resemble spawner abundance determined by video abundance because the areas of coverage are more comparable. NPT multiple pass survey information has been used for the following analysis because it is more accurate. Extensive survey expansion abundance estimates for 1998, 1999, 2001 and 2002 have varied from $214 \%$ greater to $36 \%$ fewer fish than video based spawner abundance estimates (Table 7, Figure 21). Underwater video technology determined an adult spawner abundance of 410 fish in Lake Creek in 2002 (Table 1). Extensive redd count surveys during that same year totaled 200 redds (NPT - unpublished data). Application of the PATH fish per redd numbers estimated 462 spawners in Lake Creek in 2002, which is $13 \%$ higher than the actual spawner abundance (Figure 21). The ISS approach estimated 56\% more spawners (640 fish) in Lake Creek in 2002. In 2001, underwater video technology determined an adult spawner abundance of 697 fish in Lake Creek (Table 1). Extensive redd count surveys during that same year totaled 337 redds (NPT - unpublished data). Application of the PATH fish per redd numbers estimated 778 spawners in Lake Creek in 2001, which is $12 \%$ higher than the actual spawner abundance (Figure 21). The ISS approach estimated 55\% more spawners (1,078 fish) in Lake Creek. In 1999, underwater video technology determined an adult spawner abundance of 86 fish in Lake Creek (Table 1). Extensive redd count surveys during that same year totaled 24 redds (NPT - unpublished data). Application of the PATH fish per redd numbers estimated 55 spawners in Lake Creek in 1999, which is $36 \%$ lower than the actual spawner abundance (Figure 21). The ISS approach estimated 11\% fewer spawners (77 fish) in Lake Creek in 1999. Extensive survey redd count expansions in Lake Creek in 1998 (Figure 21) proved much more variable than the 1999, 2001, or 2002 data. Salmon spawner abundance in Lake Creek in 1998 was 51 adults (Faurot et al. 2000). Extensive survey salmon redd counts during that same year counted 50 redds (NPT - unpublished data). The PATH estimated spawner abundance in Lake Creek in 1998 was 116 salmon. This was $126 \%$ greater than the spawner abundance determined with underwater video (Figure 21). ISS estimated spawner abundance was $214 \%$ greater (160 fish) than the actual spawner abundance. No expanded extensive redd count point estimates were within $\pm 10 \%$ of the actual video obtained abundance.

Index area survey redd count expansions were examined next. Again, NPT multiple pass survey information has been used for the analysis because it is more accurate. The index area redd count expansion in 1998, 1999, 2001 and 2002 varied from 182\% more to 46\% fewer fish than the actual video determined spawner abundance (Table 7, Figure 21). Underwater video technology determined an adult spawner abundance of 410 fish in Lake Creek in 2002 (Table 1). Index redd count surveys during that same year totaled 176 redds. Application of the PATH fish per redd number estimated 407 spawners in Lake Creek in 2002, which is $1 \%$ lower than the actual spawner abundance. The ISS approach estimated 37\% more spawners (563 fish) in Lake Creek (Figure 21). Underwater video technology determined an adult spawner abundance of 697 fish in Lake Creek in 2001 (Table 1). Index redd count surveys during that same year totaled 296 redds. Application of the PATH fish per redd numbers estimated 684 spawners in Lake Creek in 2001, which is $2 \%$ lower than the actual spawner abundance. The ISS 
approach estimated 36\% more spawners (947 fish) in Lake Creek (Figure 21).

Underwater video technology determined an adult spawner abundance of 86 fish in Lake

Creek in 1999 (Table 1). Index area redd count surveys during that same year totaled 20 redds (NPT - unpublished data). Application of the PATH fish per redd numbers estimated 46 spawners in Lake Creek in 1999, which is $46 \%$ lower than the actual spawner abundance (Figure 21). The ISS approach estimated 26\% fewer spawners (64 fish) in Lake Creek (NPT - unpublished data). Fifty redds were counted in the Lake Creek index area in 1998 (NPT unpublished data). The PATH expansion of index area redd counts (104 adults) (Figure 21) was $104 \%$ higher than the actual spawner abundance in Lake Creek in 1998. The ISS approach estimated 144 spawners and was $182 \%$ higher than the underwater video estimated spawner abundance (Figure 21). Only two expanded index redd count point estimates (PATH index 2001 and 2002) were within $\pm 10 \%$ of the actual video obtained abundance. PATH index estimates appear to produce the closest estimates to the actual video based abundance even though values varied from $104 \%$ greater to $46 \%$ fewer fish than the video obtained abundance.

Next, we looked at the individual redd count expansion methods over the four years (Figure 22). Using the PATH fish per redd value (2.31) to expand the index area redd count we found the expansion point estimate to range from 104\% more fish in 1998 to 46\% fewer fish in 1999 as compared to the video obtained abundance. The PATH index expanded point estimates for 2001 and 2002 were 1\% and 2\% fewer fish than the video obtained abundance. These two values were the only ones throughout the study to come within $10 \%$ of the video obtained abundance value.

The same PATH fish per redd value expanding the extensive area redd count produced expansion point estimates over the four years from 126\% more fish in 1998 to $36 \%$ fewer fish in 1999 (Figure 22). ISS expansions (3.2 fish per redd) produced index area point estimates ranging from $182 \%$ more fish to $26 \%$ fewer fish and extensive area redd count point estimates from $214 \%$ more fish to $11 \%$ fewer fish than the video obtained abundance. Again, the PATH index expansion method provided the closest estimate to the video obtained abundance.

Variation inherent in chinook salmon redd count data makes it difficult to compare data within a stream across years, between streams within a year, and between streams across years. This variation makes it difficult to use an average fish per redd number for expansion of redd count data into estimated salmon spawner abundance.

Application of the PATH fish per redd number to the index area redd count has consistently produced the most accurate escapement estimate. Application of the ISS fish per redd number to the extensive area redd count produced the highest estimates. This is intuitively obvious since the lowest average fish per redd expansion value (PATH) is being applied to the smallest stream area and vice versa when the larger ISS value is applied to the larger extensive area. In practice, total escapement is estimated by applying the average expansion value (usually PATH) to the only data available on the majority of streams, index area redd counts. This means total escapement estimates should be negatively biased. The degree of bias would depend upon the amount of 
spawning that takes place outside the index area. Comparing the expansion methods, application of the PATH value to NPT multiple-pass index area redd counts provided close estimates in 2001 and 2002, but the range of the percent differences over the project period was $104 \%$ more fish to $46 \%$ fewer fish than the video obtained abundance.

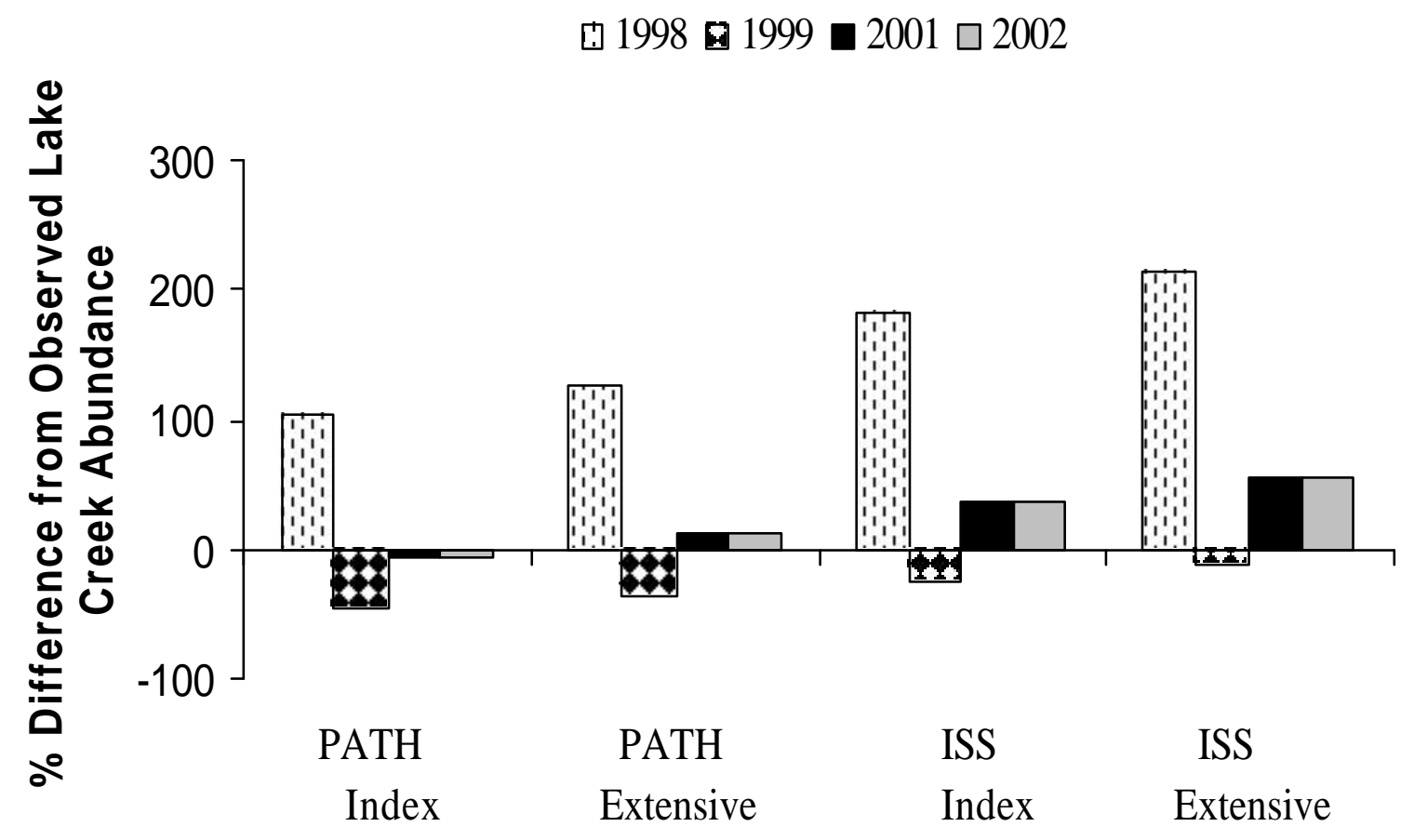

Figure 22. Estimated percent difference of various chinook salmon redd count expansions, by method, when compared to Lake Creek spawner abundance in 1998, 1999, 2001 and 2002.

Expansion of redd counts to spawner numbers are influenced by redd count measurement error and uncertainty of assumptions regarding estimates of fish per redd, relative numbers in surveyed and unsurveyed areas, prespawning mortality rates, age composition, and hatchery fish composition (Beamesderfer et al. 1998). Further error is introduced by using an average South Fork Salmon River fish per redd value (instead of an actual value) and applying it to both index and extensive survey areas in the same stream. The original purpose of annual chinook salmon redd count information was to provide only an index of relative abundance, population trends and spawning distribution over time.

Accurate spawner abundance estimates from unsupplemented salmon spawning aggregates are a necessary tool to monitor ESA listed species. Spawning ground survey redd count trend information is subject to a variety of potential sources of error. Expansion of redd count data into salmon spawner abundance estimates serves to 
magnify this variation. The underwater video technology provided an accurate assessment of spawner abundance and a benchmark to compare the redd count expansion methods. We felt video methodology provided an accurate abundance estimate for Lake Creek in 1998, 1999, 2001 and 2002. Redd count expansion methods provided highly variable estimates of salmon abundance with an unquantified error. Non biased and precise estimators are necessary for measurement of NMFS interim abundance targets for listed chinook salmon. We recommend index area redd counts continue to be used on the majority of streams in Idaho to provide an index of relative abundance, trend information and spawner distribution. However, for streams that will be used to provide population status, population growth rate and recovery metric information to satisfy requirements of the NMFS Biological Opinion (NMFS 2000), we recommend video or other more accurate methods to quantify adult salmon spawner abundance.

\section{POPULATION STATUS INFORMATION}

The NMFS (2000) Biological Opinion has developed recovery standards related to ESU status to be evaluated during the 3-, 5-, and 8-year reviews. These standards include measures of abundance, productivity trends, species diversity and population distribution. With the use of underwater time-lapse video, this project has obtained abundance estimates with 95\% C.I. for Lake Creek from 1998 to 2002 (Table 8). The video fish counting station was not installed in time to photograph the first fish in 2000 . The abundance shown is therefore a minimum escapement for 2000. The trend in adult salmon abundance over this period, including the minimum estimate in 2000, is increasing. An estimated Secesh River drainage chinook salmon spawner abundance was determined by adding the Lake Creek video determined abundance to the expanded redd count estimate for the rest of the Secesh River drainage. The Lake Creek fish per redd value for the individual year was used for the expansion.

Table 8. Adult chinook salmon spawner estimates for Lake Creek, the Secesh River excluding Lake Creek, and entire Secesh River, 1998 to 2002.

\begin{tabular}{|c|c|c|c|c|c|c|}
\hline \multirow[b]{2}{*}{ Year } & \multicolumn{2}{|c|}{ Lake Creek Video } & Secesh & \multicolumn{2}{|c|}{ River excluding Lake Creek } & \multirow{2}{*}{$\begin{array}{c}\text { Total } \\
\text { Secesh River } \\
\text { Estimate }\end{array}$} \\
\hline & Abundance & $95 \%$ C.I. & Redds & Fish/redd & Estimate & \\
\hline 2002 & 410 & \pm 4.47 & 328 & 2.05 & 672 & 1,082 \\
\hline 2001 & 697 & \pm 5.36 & 381 & 2.07 & 789 & 1,486 \\
\hline 2000 & $>325^{1}$ & \pm 24.22 & 148 & $2.18^{2}$ & 342 & $>667$ \\
\hline 1999 & 86 & \pm 10.73 & 42 & 3.58 & 150 & 236 \\
\hline 1998 & 51 & \pm 2.38 & 67 & 1.02 & 68 & 188 \\
\hline
\end{tabular}

${ }^{1}$ Incomplete sample.

${ }^{2}$ Average of 1998, 1999, 2001 and 2002 Lake Creek fish/redd values. 


\section{DESIGN AND PLACEMENT CRITERIA}

It appears that the fish counting stations can be safely installed and maintained in their present locations at an approximate river discharge of $200 \mathrm{cfs}$ in Lake Creek and $400 \mathrm{cfs}$ in the Secesh River. These sites were chosen for easier early season installation because they had straight stretches of stream that did not have areas too deep or water velocities too swift to safely wade. Riffles were avoided. In the past, fish appeared to be more wary of a structure in the shallower water and tended to accelerate through the opening. The ability to hold a fish counting station in place depended on the debris load as well as the stream discharge.

\section{FORK LENGTHS}

Fork lengths of adult salmon spawners were calculated using lasers. Three lengths were determined for each fish if possible. Videotape frames that appeared to present the fish in its longest aspect were chosen. Each length was taken from a separate videotape frame. The longest calculated length was used for the length distribution. A length-frequency distribution was determined from lasers and carcass surveys to provide a relative comparison between the two methods (Figure 23) to begin to look at age structure. From Figure 23 it can be seen that laser determined and carcass survey obtained lengths were fairly close. As predicted, the length separation between jacks and four-year old fish determined by laser is slightly less than fish from carcass surveys. There is a discrepancy in the length division between four and five-year olds determined by laser and carcass survey. Several questions must be answered before we accept the accuracy of laser determined lengths. Figure 23 plotted all adult salmon that passed through the fish counting chamber. Errors are introduced by those fish that, once upstream, migrated back downstream. If only upstream migrating fish were used for the calculations, which would still multiple-count those fish that had multiple upstream and downstream passages. These were mostly males and would skew the distribution in favor of males. If we limited the length data to only those fish that passed upstream before the male back and forth movement commenced, we would be eliminating males that migrated later.

\section{STREAM TEMPERATURE AND DISCHARGE}

Stream temperature and discharge were measured and plotted against net upstream fish movement (Figure 24). The fish counting station was installed on June 11, 2002, before peak spring runoff, at a stream discharge of approximately $200 \mathrm{cfs}$. The peak discharge measured was $352 \mathrm{cfs}$ on June 18. The first fish arrived approximately seven days la ter at a discharge of $185 \mathrm{cfs}$. Discharge diminished steadily the rest of the summer to a low of $20 \mathrm{cfs}$ when the fish counting station was removed. Average daily stream temperatures increased to a high of $15^{\circ} \mathrm{C}$ from July $12-17$ and declined to $8{ }^{\circ} \mathrm{C}$ by the end of the season. The highest water temperatures recorded $\left(19.4{ }^{\circ} \mathrm{C}\right)$ occurred in the late afternoons of July 12, 13 and 14. 


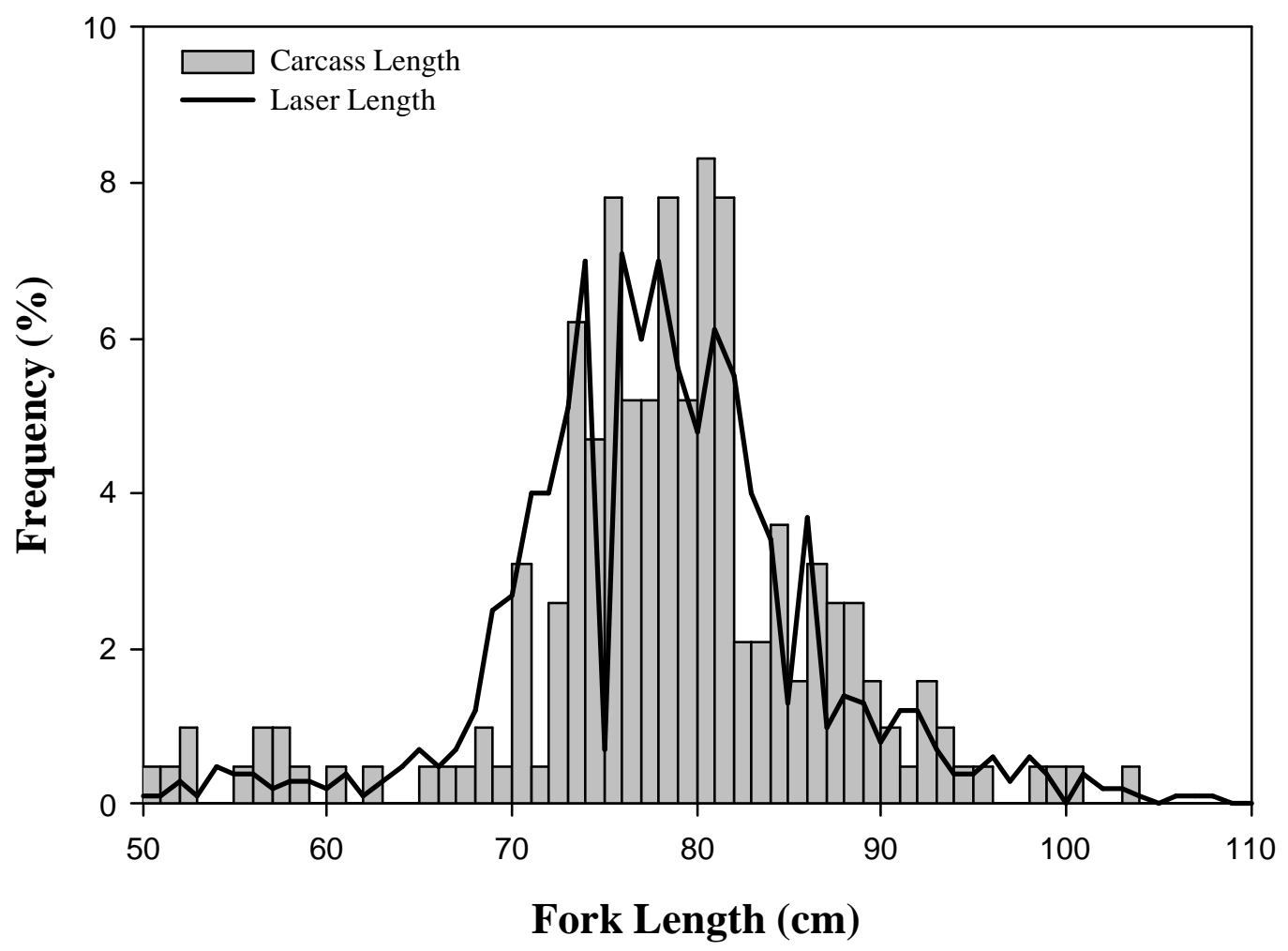

Figure 23. Carcass and laser determined length frequency distributions of adult spring and summer chinook salmon in Lake Creek in 2002.

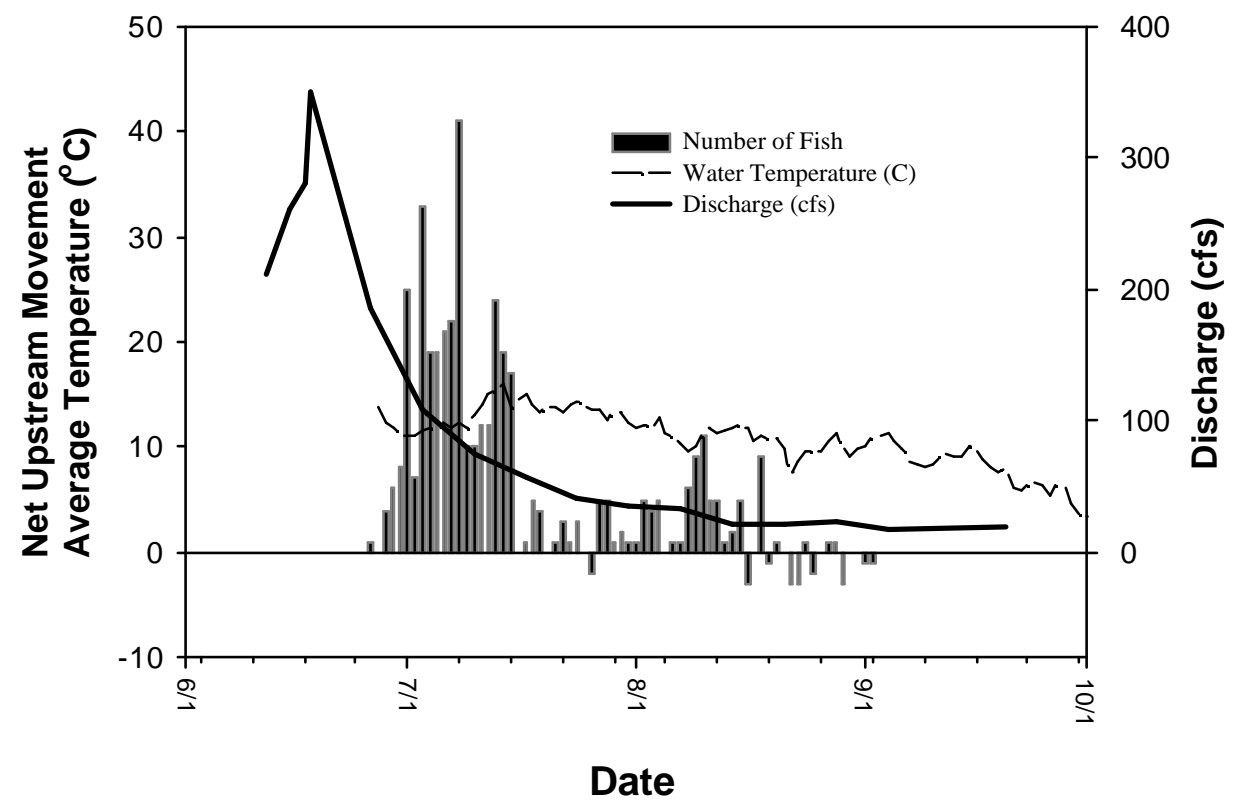

Figure 24. Chinook salmon net upstream escapement, daily average stream temperature and stream discharge at the Lake Creek fish counting station in 2002. 
The original goal of this project in 1997 was to accurately assess the spring and summer chinook salmon spawning migration into the Secesh River. One of the objectives was to test the remote application of the temporary fish counting station. The temporary structure was placed in the stream, on private property, below most of the major spawning areas. High water prevented installation of the facility in time to photograph the first adult salmon passage. We had not tested the capability of the temporary fish counting facility. In 1998, the fish counting station on the Secesh River was moved 1,000 meters downstream from the 1997 site to a better location on U. S. Forest Service land. This site was downstream of more spawning area, and was wider and shallower for earlier high water installation. And, in 1998, a second fish counting station was installed on Lake Creek, a headwater tributary of the Secesh River (Faurot et al. 2000, Faurot and Kucera 2002). Lake Creek is a smaller stream, is easier to work in, and is assumed to be a separate spawning aggregate of chinook salmon. The basic structures were installed prior to spring runoff in 1999. Like the Lake Creek structure (see above), the Secesh River structure failed during high spring flows (Figure 25). We were not able to install the Secesh River fish counting station in time to photograph the first fish passage in any year. Both fish counting stations were operated in 1998, 1999 and 2000. In 2001, the Secesh River fish counting station was not installed due to a lack of success in the previous four years. To be successful, it is imperative the fish counting station be operational in time to document the first fish passage of the season. The temporary fish counting station, in its present configuration, does not fulfill that need on the Secesh River. Increased size and discharge of the Secesh River provided more challenge. We needed to find an efficient way to determine salmon abundance in the Secesh River on an annual basis. Other potential methods of documenting the first fish passage in the Secesh River were evaluated in 2001. The desire was to use temporary structures and fish friendly methods. Some of the methodologies evaluated involved permanent structures which required a time consuming and expensive NEPA process. Most of the solutions involved newer technologies such as hydroacoustics, acoustic imaging, resistivity and electronic counters. A quad multiplexed split-beam hydroacoustic array in conjunction with underwater time-lapse video was selected as the method that would best estimate fish abundance on the Secesh River. This would provide four independent hydroacoustic counts during high flows. As flows dropped, video equipment would be installed and would become the primary abundance methodology. When both technologies were operational, results would be compared. The 2002 review and funding process of the expanded project was very slow and the full project was not implemented in 2002. In the meantime, acoustic imaging technology was improved and field tested in Alaska with favorable results. Acoustic imaging became the technology of choice for enumeration of Secesh River adult spring and summer chinook salmon in 2003. 


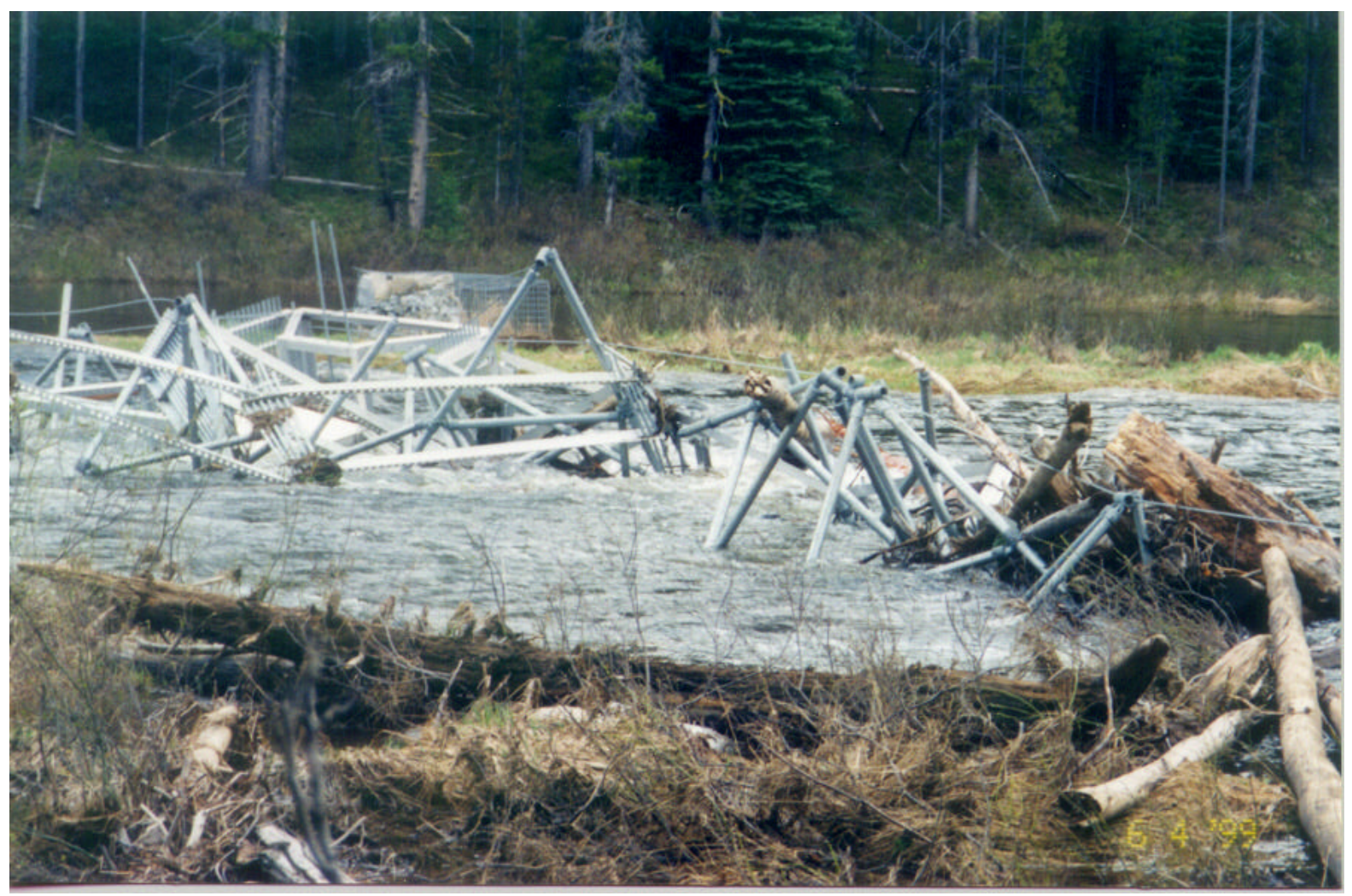

Figure 25. Failed Secesh River fish counting station.

\section{RECOMMENDATIONS}

- Provide extensive training to personnel. Early operation of the fish counting station would allow training of personnel with the new recording equipment before fish start actively migrating. This should reduce down time due to operator error and, with the additional experience, operators would be able to quickly identify and trouble shoot equipment malfunctions.

- The computerized editing system is triggered by contrast along transect lines on the videotape. Uneven sunlight and turbulence bubbles that reflect artificial night light trigger the editing system. Improve the lighting conditions in the fish counting chamber by covering it with light diffusing material to eliminate bright spots within the chamber.

- Use the computerized system for editing videotapes. With improvements in the software and more even lighting conditions in the counting chamber, the computerized editing system may be workable. Manual editing will be the primary method and provide a quality control. Fish passages would be directly edited/collapsed (at slow speed) onto another tape as time permits. Compare the results of the two methods. Determine reader efficiency on a weekly basis. 
- Prepare the Secesh River site for initial installation and testing of an acoustic imaging camera (DIDSON) system jointly operated with Pacific Northwest National Laboratory (PNNL). Install the video fish counting station in the Secesh River to monitor the spawning migration after water levels recede and to validate results from the acoustic camera.

- Implement annual adult abundance monitoring on the Secesh River at Chinook Campground to determine salmon abundance for the Secesh River. This will provide information on the only unsupplemented chinook salmon subpopulation in the South Fork Salmon River.

- Adult salmon abundance monitoring on the Secesh River will provide a measure of NMFS interim adult salmon abundance targets and recovery actions. 


\section{LITERATURE CITED}

Beamesderfer, R. C. P., H. A. Schaller, M. P. Zimmerman, C. E. Petrosky, O. P. Langness, and L. LaVoy. 1998. Spawner-recruit data for spring and summer chinook salmon populations in Idaho, Oregon and Washington. Draft report to Marmorek, D. R., and C. N. Peters (eds.). J. Anderson, R. Beamesderfer, L. Botsford, J. Collie, B. Dennis, R. Deriso, C. Ebbesmeyer, T. Fisher, R. Hinrichsen, M. Jones, O. Langness, L. LaVoy, G. Matthews, C. Paulsen, C. Petrosky, S. Saila, H. Schaller, C. Toole, C. Walters, E. Weber, P. Wilson, M. P. Zimmerman. 1998. Plan for Analyzing and Testing Hypotheses (PATH): Retrospective and Prospective Analysis of Spring/Summer Chinook Reviewed in FY 1997. Compiled and edited by ESSA Technologies Ltd. Vancouver, B. C.

Botkin, D. B., D. L. Peterson, and J. M. Calhoun (technical editors). 2000. The scientific basis for validation monitoring of salmon conservation and restoration plans. Olympic Natural Resources Technical Report. University of Washington, Olympic Natural Resources Center. Forks, Washington, USA

Bowles, E. and E. Leitzinger. 1991. Salmon supplementation studies in Idaho rivers (ISS). Experimental design. Idaho Department of Fish and Game. Prepared for Bonneville Power Administration. Portland, OR.

Calvin, L.D. 1975. Estimating Night Fish Passage over Bonneville, The Dalles and John Day Dams. U.S. Corps of Engineers Report, Portland District, OR.

Cowley, K. and P. Kucera. 1989. Chinook salmon spawning ground survey in Big Creek, Johnson Creek, Secesh River and Lake Creek, Salmon River subbasin, Idaho 1989. Nez Perce Tribe Department of Fisheries Management. Lapwai, Idaho.

Dunham, J. B., B. E. Rieman, and K. Davis. 2001. Sources and magnitude of sampling error in redd counts for bull trout Salvelinus confluentus. North American Journal of Fisheries Management 21:343-352.

Elms-Cockrum, T. E. 1999. Salmon spawning ground surveys, 1998. Idaho Department of Fish and Game. Pacific Salmon Treaty Program: Award No. NA67FP0325 IDFG 99-32, November 1999. 26 p. plus appendices.

Faurot, D. and P. A. Kucera. 1999. Escapement monitoring of adult chinook salmon in the Secesh River and Lake Creek, Idaho, 1997. Annual Report to the U. S. Department of Energy, Bonneville Power Administration by the Nez Perce Tribe Department of Fisheries Resources Management. Contract No. 97AM30423, Project No. 97-030. 
Faurot, D., P. A. Kucera and J. Hesse. 2000. Escapement monitoring of adult chinook salmon in the Secesh River and Lake Creek, Idaho, 1998. Annual Report to the U. S. Department of Energy, Bonneville Power Administration by the Nez Perce Tribe Department of Fisheries Resources Management. Contract No. 97AM30423, Project No. 97-030.

Faurot, D. and P. A. Kucera. 2001a. Adult chinook salmon abundance monitoring in the Secesh River and Lake Creek, Idaho, 1999. Annual Report to the U. S. Department of Energy, Bonneville Power Administration by the Nez Perce Tribe Department of Fisheries Resources Management. Contract No. 97AM30423, Project No. 97-030.

Faurot, D. and P. A. Kucera. 2001b. Adult chinook salmon abundance monitoring in the Secesh River and Lake Creek, Idaho, 2000. Annual Report to the U. S. Department of Energy, Bonneville Power Administration by the Nez Perce Tribe Department of Fisheries Resources Management. Contract No. 97AM30423, Project No. 97-030.

Faurot, D. and P. A. Kucera. 2002. Adult chinook salmon abundance monitoring in Lake Creek, Idaho, 2001. Annual Report to the U. S. Department of Energy, Bonneville Power Administration by the Nez Perce Tribe Department of Fisheries Resources Management. Contract No. 97AM30423, Project No. 97-030.

Fish Management Consultants. 1991. Feasibility, design and location of a weir for escapement estimation of summer chinook salmon in the Secesh River, Idaho. Report prepared for the NezPerce Tribe. Fish Management Consultants, Olympia, WA.

Foose, T. J. ,L. deBour, U. S. Seal and R. Lande. 1995. Conservation Management Strategies based on viable populations. Pages 273-294 in J. D. Ballou, M. Gilpin and T. J. Foose eds. Population Management for Survival and Recovery. Columbia University Press. New York, Chichester, West Sussex.

Hatch, D.R., M. Schwartzberg, and P.R. Mundy. 1994a. Estimation of Pacific Salmon Escapement with a Time-Lapse Video Recording Technique. North American Journal of Fisheries Management 14:626-635.

Hatch, D.R., D.R. Pederson, J.K. Fryer, M. Schwartzberg, and A. Wand. 1994b. The Feasibility of Documenting and Estimating Adult Fish Passage at Large Hydroelectric Facilities in the Snake River Using Video Technology. Columbia River Inter-Tribal Fish Commission, Annual Report to Bonneville Power Administration, Contract DE-BI79-92BP61404.

Hatch, D. R., J.K. Fryer, M. Schwartzberg, D.R. Pederson, and A. Wand. 1998. A Computerized Editing System for Video Monitoring of Fish Passage. North American Journal of Fisheries Management 18(3) 694-699. 
Hevlin, W. and S. Rainey. 1993. Considerations in the Use of Adult Fish Barriers and Traps in Tributaries to Achieve Management Objectives. Paper presented at the National American Fisheries Society Annual Meeting, 1993, Portland, OR.

Holubetz, T. B., and B.D. Leth. 1996. Evaluation and Monitoring of Wild/Natural Steelhead Trout Production. Annual Progress Report to BPA, 1995. Idaho Department of Fish and Game. Boise, ID.

Independent Scientific Group. 1993. Critical uncertainties in the Fish and Wildlife program. Bonneville Power Administration. Portland, OR.

Keifer, S., M. Rowe and K. Hatch. 1996. Stock summary reports for Columbia River anadromous salmonids, Volume V: Idaho subbasins. Prepared for BPA project Number 88-108. Idaho Department of Fish and Game. Boise, ID.

Kucera, P.A. 1987. Chinook salmon spawning ground survey in Big Creek, Johnson Creek, Secesh River and Lake Creek, Salmon River subbasin, Idaho 1987. Nez Perce Tribe Department of Fisheries Management. Lapwai, Idaho.

Kucera P. A. and M. J. Banach. 1991. Chinook salmon spawning ground survey in Big Creek, Johnson Creek, Secesh River and Lake Creek, Salmon River subbasin, Idaho - 1990. Nez Perce Tribe Department of Fisheries Management. Lapwai, Idaho.

Kucera P. A. and M.L. Blenden. 1994. Chinook salmon spawning ground survey in Big Creek, and tributary streams of the South Fork Salmon River, Idaho - 1991. In LSRCP Evaluation Studies Annual Report - 1991. AFF1/LSR-94-12. Nez Perce Tribe Department of Fisheries Resources Management. Lapwai, Idaho.

Kucera P. A. and M.L. Blenden. 1999. Chinook salmon spawning ground survey in Big Creek, and tributary streams of the South Fork Salmon River, Idaho - 1992 - 1995. Assessment of the status of salmon spawning aggregates in the Middle Fork Salmon River and South Fork Salmon River. Nez Perce Tribe Department of Fisheries Resources Management. Technical Report 99-7. Lapwai, Idaho.

Maxwell, B. A. 1999. A power analysis on the monitoring of bull trout stocks using redd counts. North American Journal of Fisheries Management 19:860-866.

McCart, P. 1969. Digging behavior of Onchorhynchus nerka spawning in streams at Babine Lake, British Columbia. In: Symposium on salmon and trout in streams, $\mathrm{T}$. G. Northcote, (ed). H. R. McMillan Lectures in Fisheries. University of British Columbia: $39-51$.

Nelson, R. L., D. C. Burns, K. L. Ketchu and D. D. Newbery. 2002. Deposition of fine in the South Fork Salmon River and Chamberlain Creek watersheds Payette and Boise National Forests, Idaho. 78 pages. Unpublished report, McCall, ID. U. S. Department of Agriculture, Payette National Forest. 
NMFS (National Marine Fisheries Service). 1992. Threatened status for Snake River spring/summer chinook salmon, threatened status for Snake River fall chinook salmon, final rule. Federal Register 57:78 (22 April 1992) 7:14, 653,663.

NMFS (National Marine Fisheries Service). 2000. Final Biological Opinion: Operation of the federal Columbia River power system including the juvenile fish transportation program and the Bureau of Reclamation's 31 projects, including the entire Columbia Basin Project. December 21, 2000

Ortmann, D. 1966. Salmo n and steelhead investigations. Investigations Project F49-R-3 (1964), Job 1: salmon and steelhead harvest and escapement studies, South Fork of Salmon River. Idaho Department of Fish and Game, Boise, ID.

River Masters Engineering. 1994. Preliminary design of a non-impeding fish counting facility in the Secesh River for adult summer chinook. Prepared for Nez Perce Tribe Fisheries Resources Management. Pullman, WA.

Roger, P. B. and M. Schwartzberg. 1986. An annotated compendium of spawning ground surveys in the Columbia River Basin above Bonneville Dam, 1960-1984. Columbia River Inter-Tribal Fish Commission Technical Report 86-1. Portland, OR.

Schwartzberg, M. and P. B. Roger. 1986. Observations on the accuracy of redd counting techniques used in the Columbia basin. Columbia River Inter-Tribal Fish Commission Technical Report 86-2.

Walters J., J. Hansen, J. Lockhart, C. Reighn, R. Keith, and Jill Olson. 2000. Idaho supplementation studies, five year report 1992 - 1996. Prepared for Bonneville Power Administration. IDFG Report Number 99-14. Idaho Department of Fish and Game, Boise, Idaho.

Williams, R. N. and 9 coauthors. 1998. Independent Scientific Advisory Board review of "Development of a regional framework for fish and wildlife restoration in the Columbia River basin”. ISAB 98-6. Independent Scientific Advisory Board. Portland, OR. 


\section{APPENDIX}

Table A-1. Run timing and direction of the spring and summer chinook salmon spawner migration in Lake Creek in 2002.

\begin{tabular}{|c|c|c|c|c|c|}
\hline $\begin{array}{l}\text { Date } \\
(2002)\end{array}$ & $\begin{array}{l}\text { Time } \\
\text { (hours) }\end{array}$ & $\begin{array}{l}\text { Direction } \\
\text { (up/down) }\end{array}$ & $\begin{array}{c}\text { Adipose Fin } \\
\text { (yes/no) }\end{array}$ & $\begin{array}{c}\text { Estimated } \\
\text { Length }(\mathrm{cm})\end{array}$ & $\begin{array}{c}\text { Net Upstream } \\
\text { Movement }\end{array}$ \\
\hline 11-Jun & - & - & - & - & 0 \\
\hline 12-Jun & - & - & - & - & 0 \\
\hline 13-Jun & - & - & - & - & 0 \\
\hline 14-Jun & - & - & - & - & 0 \\
\hline 15-Jun & - & - & - & - & 0 \\
\hline 16-Jun & - & - & - & - & 0 \\
\hline 17-Jun & - & - & - & - & 0 \\
\hline 18-Jun & - & - & - & - & 0 \\
\hline 19-Jun & - & - & - & - & 0 \\
\hline 20-Jun & - & - & - & - & 0 \\
\hline 21-Jun & - & - & - & - & 0 \\
\hline 22-Jun & - & - & - & - & 0 \\
\hline 23-Jun & - & - & - & - & 0 \\
\hline 24-Jun & Cor & ction for out & $6 / 24,15: 11$ to & $6 / 24,22: 25(0)$ & 0 \\
\hline 25-Jun & - & - & - & - & 0 \\
\hline 26-Jun & $15: 57$ & Up & Yes & 0 & 1 \\
\hline 27-Jun & - & - & - & - & 1 \\
\hline 28-Jun & $13: 22$ & $\mathrm{Up}$ & Yes & 0 & 2 \\
\hline 28-Jun & \multicolumn{4}{|c|}{ Correction for outage $6 / 2813: 27$ to $6 / 28,17: 49$ (0) } & 2 \\
\hline 28-Jun & $16: 48$ & $\mathrm{Up}$ & Yes & 66 & 3 \\
\hline 28-Jun & $17: 52$ & Up & Yes & 81 & 4 \\
\hline 28-Jun & $21: 12$ & Up & Yes & 77 & 5 \\
\hline 29-Jun & $2: 42$ & Up & Yes & 65 & 6 \\
\hline 29-Jun & $3: 40$ & Up & Yes & 69 & 7 \\
\hline 29-Jun & $10: 58$ & Up & Yes & 84 & 8 \\
\hline 29-Jun & $10: 58$ & Up & Yes & 70 & 9 \\
\hline 29-Jun & $14: 56$ & Down & Yes & 84 & 8 \\
\hline 29-Jun & $17: 27$ & Up & Yes & 72 & 9 \\
\hline 29-Jun & $22: 33$ & Up & Yes & 69 & 10 \\
\hline 29-Jun & 23:08 & Up & Yes & 85 & 11 \\
\hline 30-Jun & $18: 00$ & Up & Yes & 85 & 12 \\
\hline
\end{tabular}


Table A-1 (continued)

\begin{tabular}{|c|c|c|c|c|c|}
\hline $\begin{array}{l}\text { Date } \\
(2002)\end{array}$ & $\begin{array}{l}\text { Time } \\
\text { (hours) }\end{array}$ & $\begin{array}{c}\text { Direction } \\
\text { (up/down) }\end{array}$ & $\begin{array}{l}\text { Adipose Fin } \\
\text { (yes/no) }\end{array}$ & $\begin{array}{l}\text { Estimated } \\
\text { Length }(\mathrm{cm})\end{array}$ & $\begin{array}{c}\text { Net Upstream } \\
\text { Movement }\end{array}$ \\
\hline 30-Jun & $19: 55$ & Up & Yes & 78 & 13 \\
\hline 30-Jun & $22: 00$ & Up & Yes & 91 & 14 \\
\hline 30-Jun & 22:02 & Up & Yes & 64 & 15 \\
\hline 30 Jun & $22: 52$ & Up & Yes & 75 & 16 \\
\hline 30-Jun & 23:08 & Up & Yes & 95 & 17 \\
\hline 30-Jun & $23: 12$ & Up & Yes & 73 & 18 \\
\hline 30-Jun & $23: 15$ & Up & Yes & 79 & 19 \\
\hline 30-Jun & $23: 18$ & Down & Yes & 82 & 18 \\
\hline 30-Jun & $23: 49$ & Up & Yes & 89 & 19 \\
\hline 1-Jul & 6:02 & Up & Yes & 71 & 20 \\
\hline 1-Jul & $6: 02$ & Up & Yes & 74 & 21 \\
\hline 1-Jul & 6:08 & Up & Yes & 81 & 22 \\
\hline 1-Jul & $6: 29$ & Up & Yes & 78 & 23 \\
\hline 1-Jul & $6: 29$ & $\mathrm{Up}$ & Yes & 84 & 24 \\
\hline 1-Jul & $6: 35$ & $\mathrm{Up}$ & Yes & 70 & 25 \\
\hline 1-Jul & $13: 54$ & Up & Yes & 75 & 26 \\
\hline 1-Jul & $14: 05$ & Down & Yes & 81 & 25 \\
\hline 1-Jul & $14: 05$ & Up & Yes & 83 & 26 \\
\hline 1-Jul & 14:08 & Down & Yes & $\sim$ & 25 \\
\hline 1-Jul & $14: 08$ & Up & Yes & $\sim$ & 26 \\
\hline 1-Jul & $16: 26$ & Up & Yes & 81 & 27 \\
\hline 1-Jul & $16: 26$ & Up & Yes & 77 & 28 \\
\hline 1-Jul & $16: 27$ & Up & Yes & 74 & 29 \\
\hline 1-Jul & $16: 33$ & Up & Yes & 90 & 30 \\
\hline 1-Jul & $16: 37$ & Up & Yes & 90 & 31 \\
\hline 1-Jul & $16: 50$ & Up & Yes & 84 & 32 \\
\hline 1-Jul & $16: 51$ & Up & Yes & 79 & 33 \\
\hline 1-Jul & $16: 52$ & Up & Yes & 92 & 34 \\
\hline 1-Jul & $16: 52$ & Up & Yes & 76 & 35 \\
\hline 1-Jul & $17: 05$ & Up & Yes & 71 & 36 \\
\hline 1-Jul & $17: 14$ & Up & Yes & 86 & 37 \\
\hline 1-Jul & $18: 50$ & Up & No & 77 & 38 \\
\hline 1-Jul & $18: 50$ & Up & Yes & 74 & 39 \\
\hline 1-Jul & $18: 50$ & Up & Yes & 76 & 40 \\
\hline 1-Jul & $18: 50$ & Up & Yes & 75 & 41 \\
\hline 1-Jul & $19: 32$ & Up & Yes & 78 & 42 \\
\hline 1-Jul & 20:06 & Up & No & 71 & 43 \\
\hline 1-Jul & 23:01 & Up & Yes & 78 & 44 \\
\hline 2-Jul & $0: 23$ & Up & Yes & 54 & 45 \\
\hline 2-Jul & $16: 00$ & Up & Yes & 79 & 46 \\
\hline
\end{tabular}


Table A-1 (continued)

\begin{tabular}{|c|c|c|c|c|c|}
\hline $\begin{array}{l}\text { Date } \\
(2002)\end{array}$ & $\begin{array}{l}\text { Time } \\
\text { (hours) }\end{array}$ & $\begin{array}{r}\text { Direction } \\
\text { (up/down) }\end{array}$ & $\begin{array}{l}\text { Adipose Fin } \\
\text { (yes/no) }\end{array}$ & $\begin{array}{l}\text { Estimated } \\
\text { Length }(\mathrm{cm})\end{array}$ & $\begin{array}{c}\text { Net Upstream } \\
\text { Movement }\end{array}$ \\
\hline 2-Jul & $16: 11$ & Up & Yes & 76 & 47 \\
\hline 2-Jul & $22: 18$ & Up & Yes & 91 & 48 \\
\hline 2-Jul & $22: 20$ & Up & Yes & 85 & 49 \\
\hline 2-Jul & $22: 34$ & Up & No & 48 & 50 \\
\hline 2-Jul & $22: 46$ & Up & Yes & 91 & 51 \\
\hline 3-Jul & 0:01 & Up & Yes & 71 & 52 \\
\hline 3-Jul & 0:01 & $\mathrm{Up}$ & Yes & 82 & 53 \\
\hline 3-Jul & $1: 39$ & Up & Yes & 90 & 54 \\
\hline 3-Jul & $1: 42$ & Down & Yes & 81 & 53 \\
\hline 3-Jul & $1: 45$ & Up & Yes & 78 & 54 \\
\hline 3-Jul & $2: 21$ & Up & Yes & 93 & 55 \\
\hline 3-Jul & 6:01 & Up & Yes & 76 & 56 \\
\hline 3-Jul & $11: 11$ & Up & Yes & $\sim$ & 57 \\
\hline 3-Jul & $11: 13$ & $\mathrm{Up}$ & Yes & 79 & 58 \\
\hline 3-Jul & $15: 19$ & $\mathrm{Up}$ & Yes & 80 & 59 \\
\hline 3-Jul & $15: 32$ & Up & Yes & 84 & 60 \\
\hline 3-Jul & $16: 03$ & Up & Yes & $\sim$ & 61 \\
\hline 3-Jul & $16: 11$ & Up & Yes & $\sim$ & 62 \\
\hline 3-Jul & $16: 11$ & Up & Yes & 92 & 63 \\
\hline 3-Jul & $16: 17$ & Up & Yes & 80 & 64 \\
\hline 3-Jul & $16: 42$ & Up & Yes & 80 & 65 \\
\hline 3-Jul & $16: 42$ & Up & Yes & 92 & 66 \\
\hline 3-Jul & $16: 49$ & Up & Yes & 103 & 67 \\
\hline 3-Jul & $17: 15$ & Up & Yes & 91 & 68 \\
\hline 3-Jul & $17: 53$ & Up & No & 74 & 69 \\
\hline 3-Jul & $18: 34$ & Up & Yes & 75 & 70 \\
\hline 3-Jul & $18: 59$ & Up & Yes & 86 & 71 \\
\hline 3-Jul & $18: 59$ & Up & Yes & 84 & 72 \\
\hline 3-Jul & $19: 00$ & Up & Yes & 77 & 73 \\
\hline 3-Jul & $19: 00$ & Up & Yes & 89 & 74 \\
\hline 3-Jul & 19:01 & Up & Yes & 75 & 75 \\
\hline 3-Jul & $19: 07$ & Up & Yes & 87 & 76 \\
\hline 3-Jul & $19: 09$ & Up & Yes & 86 & 77 \\
\hline 3-Jul & $19: 56$ & Up & Yes & 75 & 78 \\
\hline 3-Jul & $20: 13$ & Up & Yes & 78 & 79 \\
\hline 3-Jul & $20: 44$ & Up & Yes & 84 & 80 \\
\hline 3-Jul & $20: 44$ & Up & Yes & 75 & 81 \\
\hline 3-Jul & $21: 14$ & Up & Yes & 66 & 82 \\
\hline 3-Jul & 21:24 & Up & Yes & 73 & 83 \\
\hline 3-Jul & $23: 24$ & Up & Yes & 87 & 84 \\
\hline
\end{tabular}


Table A-1 (continued)

\begin{tabular}{|c|c|c|c|c|c|}
\hline $\begin{array}{l}\text { Date } \\
(2002)\end{array}$ & $\begin{array}{l}\text { Time } \\
\text { (hours) }\end{array}$ & $\begin{array}{r}\text { Direction } \\
\text { (up/down) }\end{array}$ & $\begin{array}{l}\text { Adipose Fin } \\
\text { (yes/no) }\end{array}$ & $\begin{array}{l}\text { Estimated } \\
\text { Length }(\mathrm{cm})\end{array}$ & $\begin{array}{c}\text { Net Upstream } \\
\text { Movement }\end{array}$ \\
\hline 4-Jul & $1: 54$ & Up & Yes & 91 & 85 \\
\hline 4-Jul & $4: 14$ & Up & Yes & 98 & 86 \\
\hline 4-Jul & $5: 55$ & Down & Yes & 75 & 85 \\
\hline 4-Jul & $5: 56$ & Down & Yes & 81 & 84 \\
\hline 4-Jul & $6: 01$ & Up & No & 84 & 85 \\
\hline 4-Jul & $9: 48$ & Up & Yes & 88 & 86 \\
\hline 4-Jul & $16: 17$ & $\mathrm{Up}$ & No & 74 & 87 \\
\hline 4-Jul & $16: 21$ & Up & Yes & 90 & 88 \\
\hline 4-Jul & $16: 27$ & $\mathrm{Up}$ & Yes & 83 & 89 \\
\hline 4-Jul & $16: 28$ & Up & Yes & 83 & 90 \\
\hline 4-Jul & $16: 31$ & Up & Yes & 57 & 91 \\
\hline 4-Jul & $16: 47$ & Up & Yes & 84 & 92 \\
\hline 4-Jul & $16: 48$ & Up & Yes & 75 & 93 \\
\hline 4-Jul & $16: 53$ & $\mathrm{Up}$ & Yes & 79 & 94 \\
\hline 4-Jul & $16: 54$ & Up & Yes & 95 & 95 \\
\hline 4-Jul & $16: 58$ & Up & Yes & 89 & 96 \\
\hline 4-Jul & $16: 59$ & Up & Yes & 96 & 97 \\
\hline 4-Jul & $17: 04$ & $\mathrm{Up}$ & Yes & 81 & 98 \\
\hline 4-Jul & $17: 38$ & Up & Yes & 78 & 99 \\
\hline 4-Jul & $17: 39$ & $\mathrm{Up}$ & Yes & 93 & 100 \\
\hline 4-Jul & $18: 20$ & Up & Yes & 79 & 101 \\
\hline 4-Jul & $23: 11$ & Up & Yes & 92 & 102 \\
\hline 4-Jul & $23: 22$ & Up & Yes & 72 & 103 \\
\hline 5-Jul & 1:09 & Up & No & 85 & 104 \\
\hline 5-Jul & $1: 28$ & Up & Yes & 76 & 105 \\
\hline 5-Jul & $1: 44$ & Up & Yes & 76 & 106 \\
\hline 5-Jul & $2: 32$ & Down & Yes & 76 & 105 \\
\hline 5-Jul & $2: 32$ & Up & Yes & 80 & 106 \\
\hline 5-Jul & $2: 35$ & Down & Yes & 82 & 105 \\
\hline 5-Jul & $2: 37$ & Up & Yes & 76 & 106 \\
\hline 5-Jul & $2: 40$ & Down & Yes & 78 & 105 \\
\hline 5-Jul & $2: 42$ & Down & Yes & $\sim$ & 104 \\
\hline 5-Jul & $4: 36$ & Down & Yes & 70 & 103 \\
\hline 5-Jul & $5: 11$ & Down & Yes & 90 & 102 \\
\hline 5-Jul & $5: 13$ & Up & Yes & 96 & 103 \\
\hline 5-Jul & $5: 19$ & Down & Yes & 93 & 102 \\
\hline 5-Jul & $5: 42$ & Up & Yes & 82 & 103 \\
\hline 5-Jul & $5: 48$ & $\mathrm{Up}$ & Yes & 75 & 104 \\
\hline 5-Jul & $6: 27$ & Down & Yes & 86 & 103 \\
\hline 5-Jul & $6: 33$ & Up & Yes & 88 & 104 \\
\hline
\end{tabular}


Table A-1 (continued)

\begin{tabular}{|c|c|c|c|c|c|}
\hline $\begin{array}{l}\text { Date } \\
(2002)\end{array}$ & $\begin{array}{l}\text { Time } \\
\text { (hours) }\end{array}$ & $\begin{array}{r}\text { Direction } \\
\text { (up/down) }\end{array}$ & $\begin{array}{l}\text { Adipose Fin } \\
\text { (yes/no) }\end{array}$ & $\begin{array}{l}\text { Estimated } \\
\text { Length }(\mathrm{cm})\end{array}$ & $\begin{array}{c}\text { Net Upstream } \\
\text { Movement }\end{array}$ \\
\hline 5-Jul & $6: 51$ & Up & Yes & 72 & 105 \\
\hline 5-Jul & $6: 51$ & Up & Yes & 83 & 106 \\
\hline 5-Jul & $7: 20$ & Up & Yes & 79 & 107 \\
\hline 5-Jul & 8:08 & Down & Yes & 68 & 106 \\
\hline 5-Jul & $12: 56$ & Up & Yes & 78 & 107 \\
\hline 5-Jul & $13: 17$ & Down & Yes & 86 & 106 \\
\hline 5-Jul & $17: 26$ & Up & No & 77 & 107 \\
\hline 5-Jul & $18: 50$ & Up & Yes & 77 & 108 \\
\hline 5-Jul & $18: 59$ & $\mathrm{Up}$ & Yes & 76 & 109 \\
\hline 5-Jul & 19:01 & Up & Yes & 67 & 110 \\
\hline 5-Jul & $19: 05$ & Up & Yes & 79 & 111 \\
\hline 5-Jul & $19: 05$ & Up & Yes & 71 & 112 \\
\hline 5-Jul & $19: 10$ & Up & Yes & 76 & 113 \\
\hline 5-Jul & $19: 10$ & $\mathrm{Up}$ & Yes & 78 & 114 \\
\hline 5-Jul & $19: 11$ & $\mathrm{Up}$ & Yes & 70 & 115 \\
\hline 5-Jul & $19: 46$ & Up & No & 81 & 116 \\
\hline 5-Jul & $19: 52$ & Up & Yes & 76 & 117 \\
\hline 5-Jul & $19: 52$ & $\mathrm{Up}$ & Yes & 79 & 118 \\
\hline 5-Jul & $19: 59$ & Up & Yes & 81 & 119 \\
\hline 5-Jul & $19: 59$ & $\mathrm{Up}$ & Yes & 61 & 120 \\
\hline 5-Jul & $23: 37$ & Up & Yes & 78 & 121 \\
\hline 5-Jul & $23: 51$ & Up & Yes & 72 & 122 \\
\hline 6-Jul & $0: 13$ & Up & Yes & 75 & 123 \\
\hline 6-Jul & $0: 16$ & Down & Yes & 76 & 122 \\
\hline 6-Jul & $0: 24$ & Up & No & 99 & 123 \\
\hline 6-Jul & $3: 50$ & Up & Yes & $\sim$ & 124 \\
\hline 6-Jul & $3: 54$ & Up & Yes & 73 & 125 \\
\hline 6-Jul & 4:00 & Up & Yes & 55 & 126 \\
\hline 6-Jul & $4: 43$ & Down & Yes & 90 & 125 \\
\hline 6-Jul & $7: 34$ & Up & Yes & 80 & 126 \\
\hline 6-Jul & $8: 15$ & Up & Yes & 74 & 127 \\
\hline 6-Jul & $17: 42$ & $\mathrm{Up}$ & Yes & 57 & 128 \\
\hline 6-Jul & $17: 42$ & Up & Yes & 84 & 129 \\
\hline 6-Jul & $17: 44$ & Up & Yes & 86 & 130 \\
\hline 6-Jul & $17: 44$ & Up & Yes & 80 & 131 \\
\hline 6-Jul & $17: 44$ & Up & Yes & 67 & 132 \\
\hline 6-Jul & $17: 51$ & Up & Yes & 75 & 133 \\
\hline 6-Jul & 18:17 & Up & Yes & 78 & 134 \\
\hline 6-Jul & $18: 29$ & Up & Yes & 83 & 135 \\
\hline 6-Jul & $18: 33$ & Up & No & 92 & 136 \\
\hline
\end{tabular}


Table A-1 (continued)

\begin{tabular}{|c|c|c|c|c|c|}
\hline $\begin{array}{l}\text { Date } \\
(2002)\end{array}$ & $\begin{array}{l}\text { Time } \\
\text { (hours) }\end{array}$ & $\begin{array}{l}\text { Direction } \\
\text { (up/down) }\end{array}$ & $\begin{array}{l}\text { Adipose Fin } \\
\text { (yes/no) }\end{array}$ & $\begin{array}{l}\text { Estimated } \\
\text { Length }(\mathrm{cm}\end{array}$ & $\begin{array}{c}\text { Net Upstream } \\
\text { Movement }\end{array}$ \\
\hline 6-Jul & $20: 35$ & Up & Yes & 75 & 137 \\
\hline 6-Jul & 21:07 & Up & Yes & 82 & 138 \\
\hline 6-Jul & 21:07 & Up & Yes & 80 & 139 \\
\hline 6-Jul & $21: 21$ & Up & Yes & 75 & 140 \\
\hline 6-Jul & $22: 51$ & Up & Yes & 100 & 141 \\
\hline 6-Jul & 23:02 & Up & Yes & 100 & 142 \\
\hline 6-Jul & $23: 35$ & $\mathrm{Up}$ & Yes & 88 & 143 \\
\hline 7-Jul & $1: 49$ & Up & Yes & 87 & 144 \\
\hline 7-Jul & $1: 57$ & $\mathrm{Up}$ & Yes & 96 & 145 \\
\hline 7-Jul & 2:02 & Down & Yes & 70 & 144 \\
\hline 7-Jul & 2:04 & Up & Yes & 87 & 145 \\
\hline 7-Jul & $2: 10$ & Up & Yes & 101 & 146 \\
\hline 7-Jul & $2: 37$ & Down & Yes & 83 & 145 \\
\hline 7-Jul & $2: 59$ & Up & Yes & 82 & 146 \\
\hline 7-Jul & $6: 41$ & Up & Yes & 75 & 147 \\
\hline 7-Jul & $6: 58$ & Up & Yes & 79 & 148 \\
\hline 7-Jul & 7:05 & Up & Yes & 86 & 149 \\
\hline 7-Jul & 8:02 & Up & Yes & 87 & 150 \\
\hline 7-Jul & $11: 37$ & Up & Yes & 75 & 151 \\
\hline 7-Jul & $14: 30$ & $\mathrm{Up}$ & Yes & 80 & 152 \\
\hline 7-Jul & $14: 30$ & Up & Yes & 47 & 153 \\
\hline 7-Jul & $14: 58$ & Up & Yes & 87 & 154 \\
\hline 7-Jul & $15: 08$ & Up & Yes & 81 & 155 \\
\hline 7-Jul & $15: 20$ & Up & Yes & 79 & 156 \\
\hline 7-Jul & $15: 22$ & Up & Yes & 81 & 157 \\
\hline 7-Jul & $15: 31$ & Up & Yes & 82 & 158 \\
\hline 7-Jul & $15: 32$ & Up & Yes & 82 & 159 \\
\hline 7-Jul & $15: 53$ & Up & Yes & 74 & 160 \\
\hline 7-Jul & $15: 56$ & Up & Yes & 75 & 161 \\
\hline 7-Jul & $16: 28$ & Down & Yes & 76 & 160 \\
\hline 7-Jul & $16: 40$ & Down & Yes & 81 & 159 \\
\hline 7-Jul & $16: 40$ & Down & Yes & 77 & 158 \\
\hline 7-Jul & $16: 40$ & Down & Yes & $\sim$ & 157 \\
\hline 7-Jul & $16: 43$ & Down & Yes & 71 & 156 \\
\hline 7-Jul & $16: 58$ & Up & Yes & 81 & 157 \\
\hline 7-Jul & $17: 18$ & Up & Yes & 77 & 158 \\
\hline 7-Jul & $18: 44$ & Up & Yes & 79 & 159 \\
\hline 7-Jul & $18: 44$ & Up & Yes & 59 & 160 \\
\hline 7-Jul & $18: 47$ & Up & Yes & 88 & 161 \\
\hline 7-Jul & $20: 16$ & Up & Yes & 95 & 162 \\
\hline
\end{tabular}


Table A-1 (continued)

\begin{tabular}{|c|c|c|c|c|c|}
\hline $\begin{array}{l}\text { Date } \\
(2002)\end{array}$ & $\begin{array}{l}\text { Time } \\
\text { (hours) }\end{array}$ & $\begin{array}{r}\text { Direction } \\
\text { (up/down) }\end{array}$ & $\begin{array}{l}\text { Adipose Fin } \\
\text { (yes/no) }\end{array}$ & $\begin{array}{l}\text { Estimated } \\
\text { Length }(\mathrm{cm})\end{array}$ & $\begin{array}{c}\text { Net Upstream } \\
\text { Movement }\end{array}$ \\
\hline 7-Jul & $20: 53$ & Up & Yes & 91 & 163 \\
\hline 7-Jul & $21: 11$ & Up & Yes & 89 & 164 \\
\hline 7-Jul & 23:01 & Down & Yes & 86 & 163 \\
\hline 7-Jul & $23: 47$ & Up & Yes & 84 & 165 \\
\hline 8-Jul & $0: 33$ & Up & Yes & 85 & 166 \\
\hline 8-Jul & $0: 36$ & Up & Yes & 78 & 167 \\
\hline 8-Jul & $0: 36$ & $\mathrm{Up}$ & Yes & 86 & 168 \\
\hline 8-Jul & $0: 43$ & Up & Yes & 83 & 169 \\
\hline 8-Jul & $0: 47$ & $\mathrm{Up}$ & Yes & 67 & 170 \\
\hline 8-Jul & 2:04 & Up & Yes & 98 & 171 \\
\hline 8-Jul & 2:06 & Up & Yes & 82 & 172 \\
\hline 8-Jul & $3: 29$ & Up & Yes & 82 & 173 \\
\hline 8-Jul & $4: 26$ & Up & Yes & 56 & 174 \\
\hline 8-Jul & 6:09 & Up & Yes & 81 & 175 \\
\hline 8-Jul & $6: 24$ & Down & Yes & 73 & 174 \\
\hline 8-Jul & $6: 30$ & Up & Yes & 80 & 175 \\
\hline 8-Jul & $6: 35$ & Up & Yes & 81 & 176 \\
\hline 8-Jul & $10: 50$ & $\mathrm{Up}$ & Yes & 93 & 177 \\
\hline 8-Jul & $10: 50$ & Up & Yes & 56 & 178 \\
\hline 8-Jul & $10: 54$ & $\mathrm{Up}$ & No & 82 & 179 \\
\hline 8-Jul & $10: 56$ & Up & Yes & 84 & 180 \\
\hline 8-Jul & 11:01 & Up & Yes & 80 & 181 \\
\hline 8-Jul & $11: 38$ & Up & Yes & 78 & 182 \\
\hline 8-Jul & $11: 56$ & Up & Yes & $\sim$ & 183 \\
\hline 8-Jul & $12: 29$ & Up & No & 77 & 184 \\
\hline 8-Jul & $12: 29$ & Up & Yes & 82 & 185 \\
\hline 8-Jul & $12: 31$ & Up & Yes & 89 & 186 \\
\hline 8-Jul & $12: 31$ & Up & Yes & 80 & 187 \\
\hline 8-Jul & $12: 49$ & Up & Yes & 73 & 188 \\
\hline 8-Jul & $12: 54$ & Up & Yes & 86 & 189 \\
\hline 8-Jul & $13: 16$ & Up & Yes & 79 & 190 \\
\hline 8-Jul & $13: 26$ & $\mathrm{Up}$ & Yes & 108 & 191 \\
\hline 8-Jul & $13: 26$ & Up & Yes & 81 & 192 \\
\hline 8-Jul & $15: 57$ & Up & Yes & 81 & 193 \\
\hline 8-Jul & $15: 57$ & Up & Yes & 75 & 194 \\
\hline 8-Jul & $16: 01$ & Up & Yes & 86 & 195 \\
\hline 8-Jul & $16: 46$ & Up & Yes & 81 & 196 \\
\hline 8-Jul & $16: 46$ & Up & Yes & 75 & 197 \\
\hline 8-Jul & $16: 50$ & Up & No & 95 & 198 \\
\hline 8-Jul & $17: 00$ & Up & Yes & 79 & 199 \\
\hline
\end{tabular}


Table A-1 (continued)

\begin{tabular}{|c|c|c|c|c|c|}
\hline $\begin{array}{l}\text { Date } \\
(2002)\end{array}$ & $\begin{array}{l}\text { Time } \\
\text { (hours) }\end{array}$ & $\begin{array}{r}\text { Direction } \\
\text { (up/down) }\end{array}$ & $\begin{array}{l}\text { Adipose Fin } \\
\text { (yes/no) }\end{array}$ & $\begin{array}{l}\text { Estimated } \\
\text { Length }(\mathrm{cm})\end{array}$ & $\begin{array}{c}\text { Net Upstream } \\
\text { Movement }\end{array}$ \\
\hline 8-Jul & $18: 07$ & Up & Yes & 85 & 200 \\
\hline 8-Jul & $18: 28$ & Up & Yes & 80 & 201 \\
\hline 8-Jul & $22: 44$ & Up & Yes & 81 & 202 \\
\hline 8-Jul & 23:09 & Up & Yes & 86 & 203 \\
\hline 8-Jul & $23: 23$ & Up & Yes & 88 & 204 \\
\hline 8-Jul & $23: 29$ & Up & Yes & 79 & 205 \\
\hline 8-Jul & $23: 29$ & Up & Yes & 87 & 206 \\
\hline 9-Jul & $0: 13$ & Down & Yes & $\sim$ & 205 \\
\hline 9-Jul & $0: 17$ & Up & Yes & 90 & 206 \\
\hline 9-Jul & $1: 27$ & Up & Yes & 63 & 207 \\
\hline 9-Jul & $2: 28$ & $\mathrm{Up}$ & Yes & 84 & 208 \\
\hline 9-Jul & $2: 34$ & Down & Yes & 78 & 207 \\
\hline 9-Jul & $2: 39$ & Up & Yes & 80 & 208 \\
\hline 9-Jul & $4: 52$ & Up & Yes & 70 & 209 \\
\hline 9-Jul & $5: 15$ & Down & Yes & 71 & 208 \\
\hline 9-Jul & $5: 15$ & Down & Yes & 81 & 207 \\
\hline 9-Jul & $5: 19$ & Up & Yes & 76 & 208 \\
\hline 9-Jul & $5: 22$ & Down & Yes & 94 & 207 \\
\hline 9-Jul & $5: 26$ & Down & Yes & 84 & 206 \\
\hline 9-Jul & $5: 29$ & Up & Yes & 77 & 207 \\
\hline 9-Jul & $5: 39$ & Up & Yes & 58 & 208 \\
\hline 9-Jul & $6: 54$ & Up & Yes & 57 & 209 \\
\hline 9-Jul & $10: 02$ & $\mathrm{Up}$ & Yes & 78 & 210 \\
\hline 9-Jul & $13: 05$ & Up & Yes & 82 & 211 \\
\hline 9-Jul & $14: 43$ & Up & Yes & 80 & 212 \\
\hline 9-Jul & $14: 45$ & Up & Yes & 78 & 213 \\
\hline 9-Jul & $14: 55$ & Up & Yes & 81 & 214 \\
\hline 9-Jul & $16: 22$ & Up & Yes & 79 & 215 \\
\hline 9-Jul & $17: 53$ & Up & Yes & 82 & 216 \\
\hline 9-Jul & $20: 36$ & Up & Yes & 90 & 217 \\
\hline 9-Jul & $22: 52$ & Up & Yes & 71 & 218 \\
\hline 9-Jul & $23: 40$ & Down & Yes & 86 & 217 \\
\hline 9-Jul & $23: 47$ & Up & Yes & 89 & 218 \\
\hline 9-Jul & $23: 57$ & Down & Yes & 82 & 217 \\
\hline 9-Jul & $23: 59$ & Down & Yes & 99 & 216 \\
\hline 10-Jul & 0:06 & Up & Yes & 97 & 217 \\
\hline 10-Jul & $0: 38$ & Down & Yes & 93 & 216 \\
\hline 10-Jul & 3:03 & Down & Yes & 92 & 215 \\
\hline 10-Jul & 5:08 & Down & Yes & 67 & 214 \\
\hline 10-Jul & $5: 34$ & Up & Yes & 69 & 215 \\
\hline
\end{tabular}


Table A-1 (continued)

\begin{tabular}{|c|c|c|c|c|c|}
\hline $\begin{array}{l}\text { Date } \\
(2002)\end{array}$ & $\begin{array}{l}\text { Time } \\
\text { (hours) }\end{array}$ & $\begin{array}{r}\text { Direction } \\
\text { (up/down) }\end{array}$ & $\begin{array}{l}\text { Adipose Fin } \\
\text { (yes/no) }\end{array}$ & $\begin{array}{l}\text { Estimated } \\
\text { Length }(\mathrm{cm})\end{array}$ & $\begin{array}{c}\text { Net Upstream } \\
\text { Movement }\end{array}$ \\
\hline 10-Jul & $5: 38$ & Down & Yes & 65 & 214 \\
\hline 10-Jul & $6: 02$ & Down & Yes & 84 & 213 \\
\hline 10-Jul & $6: 04$ & Up & Yes & 72 & 214 \\
\hline 10-Jul & $12: 54$ & $\mathrm{Up}$ & Yes & 80 & 215 \\
\hline 10-Jul & $12: 59$ & Up & Yes & 82 & 216 \\
\hline 10-Jul & $12: 59$ & Up & Yes & 69 & 217 \\
\hline 10-Jul & $13: 05$ & $\mathrm{Up}$ & Yes & $\sim$ & 218 \\
\hline 10-Jul & $13: 55$ & Up & Yes & 61 & 219 \\
\hline 10-Jul & $14: 25$ & $\mathrm{Up}$ & Yes & 83 & 220 \\
\hline 10-Jul & $17: 30$ & Up & Yes & 81 & 221 \\
\hline 10-Jul & $18: 36$ & Up & Yes & 57 & 222 \\
\hline 10-Jul & 22:02 & Up & Yes & 60 & 223 \\
\hline 10-Jul & $22: 14$ & Up & Yes & 96 & 224 \\
\hline 10-Jul & $22: 24$ & Up & Yes & 83 & 225 \\
\hline 10-Jul & $22: 59$ & Down & Yes & 94 & 224 \\
\hline 10-Jul & $23: 00$ & Up & Yes & 85 & 225 \\
\hline 10-Jul & $23: 36$ & $\mathrm{Up}$ & Yes & 62 & 226 \\
\hline 11-Jul & $0: 45$ & Down & Yes & 88 & 225 \\
\hline 11-Jul & $0: 50$ & Up & Yes & 103 & 226 \\
\hline 11-Jul & $0: 53$ & $\mathrm{Up}$ & Yes & 88 & 227 \\
\hline 11-Jul & $0: 54$ & Down & Yes & 92 & 226 \\
\hline 11-Jul & $1: 02$ & Up & Yes & 101 & 227 \\
\hline 11-Jul & $1: 35$ & Down & Yes & 89 & 226 \\
\hline 11-Jul & $1: 37$ & Up & Yes & 93 & 227 \\
\hline 11-Jul & $1: 39$ & Down & Yes & 83 & 226 \\
\hline 11-Jul & $1: 40$ & Up & Yes & 53 & 227 \\
\hline 11-Jul & $1: 50$ & Down & Yes & 52 & 226 \\
\hline 11-Jul & $1: 59$ & Down & Yes & 93 & 225 \\
\hline 11-Jul & 2:04 & Up & Yes & 53 & 226 \\
\hline 11-Jul & $2: 18$ & Up & Yes & 80 & 227 \\
\hline 11-Jul & $2: 57$ & Up & Yes & 79 & 228 \\
\hline 11-Jul & 3:08 & Down & Yes & 64 & 227 \\
\hline 11-Jul & $3: 17$ & Down & Yes & 77 & 226 \\
\hline 11-Jul & $3: 50$ & Up & Yes & 70 & 227 \\
\hline 11-Jul & $3: 51$ & Down & Yes & $\sim$ & 226 \\
\hline 11-Jul & $3: 54$ & Up & Yes & 84 & 227 \\
\hline 11-Jul & $3: 54$ & Down & Yes & 71 & 226 \\
\hline 11-Jul & 4:03 & Down & Yes & 79 & 225 \\
\hline 11-Jul & 4:07 & Up & Yes & 79 & 226 \\
\hline 11-Jul & $4: 12$ & Down & Yes & 75 & 225 \\
\hline
\end{tabular}


Table A-1 (continued)

\begin{tabular}{|c|c|c|c|c|c|}
\hline $\begin{array}{l}\text { Date } \\
(2002)\end{array}$ & $\begin{array}{l}\text { Time } \\
\text { (hours) }\end{array}$ & $\begin{array}{r}\text { Direction } \\
\text { (up/down) }\end{array}$ & $\begin{array}{l}\text { Adipose Fin } \\
\text { (yes/no) }\end{array}$ & $\begin{array}{l}\text { Estimated } \\
\text { Length }(\mathrm{cm})\end{array}$ & $\begin{array}{c}\text { Net Upstream } \\
\text { Movement }\end{array}$ \\
\hline 11-Jul & $7: 14$ & Down & Yes & 74 & 224 \\
\hline 11-Jul & $7: 17$ & Up & Yes & 78 & 225 \\
\hline 11-Jul & $7: 18$ & Down & Yes & 74 & 224 \\
\hline 11-Jul & $7: 19$ & $\mathrm{Up}$ & Yes & 81 & 225 \\
\hline 11-Jul & $7: 23$ & Down & Yes & 72 & 224 \\
\hline 11-Jul & $7: 24$ & Up & Yes & 75 & 225 \\
\hline 11-Jul & $7: 27$ & Down & Yes & 82 & 224 \\
\hline 11-Jul & $11: 50$ & Up & Yes & 74 & 225 \\
\hline 11-Jul & $12: 39$ & $\mathrm{Up}$ & Yes & 82 & 226 \\
\hline 11-Jul & $13: 03$ & Up & Yes & 82 & 227 \\
\hline 11-Jul & $13: 04$ & Up & Yes & 75 & 228 \\
\hline 11-Jul & $13: 06$ & Up & Yes & 83 & 229 \\
\hline 11-Jul & $14: 11$ & Up & Yes & 91 & 230 \\
\hline 11-Jul & $14: 11$ & $\mathrm{Up}$ & Yes & 72 & 231 \\
\hline 11-Jul & $16: 22$ & $\mathrm{Up}$ & Yes & 88 & 232 \\
\hline 11-Jul & $16: 29$ & Up & Yes & 77 & 233 \\
\hline 11-Jul & $16: 37$ & Up & Yes & 79 & 234 \\
\hline 11-Jul & $16: 49$ & Up & Yes & 86 & 235 \\
\hline 11-Jul & $16: 51$ & Up & Yes & 79 & 236 \\
\hline 11-Jul & $20: 55$ & $\mathrm{Up}$ & Yes & 75 & 237 \\
\hline 11-Jul & $22: 12$ & Up & Yes & 78 & 238 \\
\hline 12-Jul & 0:06 & Up & Yes & 78 & 239 \\
\hline 12-Jul & $0: 18$ & Up & Yes & 69 & 240 \\
\hline 12-Jul & $0: 19$ & Down & Yes & 70 & 239 \\
\hline 12-Jul & $2: 49$ & Down & Yes & 89 & 238 \\
\hline 12-Jul & 3:00 & Up & Yes & 81 & 239 \\
\hline 12-Jul & $5: 26$ & Up & Yes & 81 & 240 \\
\hline 12-Jul & $7: 33$ & Up & Yes & 71 & 241 \\
\hline 12-Jul & $8: 50$ & Up & Yes & 83 & 242 \\
\hline 12-Jul & 9:03 & Up & Yes & 81 & 243 \\
\hline 12-Jul & $9: 51$ & Up & Yes & 76 & 244 \\
\hline 12-Jul & $10: 16$ & $\mathrm{Up}$ & Yes & 94 & 245 \\
\hline 12-Jul & $12: 13$ & Up & Yes & 96 & 246 \\
\hline 12-Jul & $12: 32$ & Up & Yes & 100 & 247 \\
\hline 12-Jul & $12: 34$ & Up & Yes & 97 & 248 \\
\hline 12-Jul & $14: 29$ & Down & Yes & 79 & 247 \\
\hline 12-Jul & $15: 11$ & Down & Yes & 70 & 246 \\
\hline 12-Jul & 17:06 & Up & Yes & 83 & 247 \\
\hline 12-Jul & 17:06 & Up & Yes & 71 & 248 \\
\hline 12-Jul & $17: 52$ & Up & No & 88 & 249 \\
\hline
\end{tabular}


Table A-1 (continued)

\begin{tabular}{|c|c|c|c|c|c|}
\hline $\begin{array}{l}\text { Date } \\
(2002)\end{array}$ & $\begin{array}{l}\text { Time } \\
\text { (hours) }\end{array}$ & $\begin{array}{r}\text { Direction } \\
\text { (up/down) }\end{array}$ & $\begin{array}{l}\text { Adipose Fin } \\
\text { (yes/no) }\end{array}$ & $\begin{array}{l}\text { Estimated } \\
\text { Length }(\mathrm{cm})\end{array}$ & $\begin{array}{c}\text { Net Upstream } \\
\text { Movement }\end{array}$ \\
\hline 12-Jul & $18: 42$ & Up & Yes & 82 & 250 \\
\hline 12-Jul & $19: 08$ & Down & Yes & 91 & 249 \\
\hline 12-Jul & $21: 32$ & Up & Yes & 76 & 250 \\
\hline 12-Jul & $22: 24$ & Down & Yes & 71 & 249 \\
\hline 12-Jul & 23:06 & Up & Yes & 90 & 250 \\
\hline 13-Jul & 1:39 & Up & Yes & 101 & 251 \\
\hline 13-Jul & $1: 43$ & Down & Yes & 99 & 250 \\
\hline 13-Jul & 3:00 & Up & Yes & 97 & 251 \\
\hline 13-Jul & 3:07 & $\mathrm{Up}$ & Yes & 88 & 252 \\
\hline 13-Jul & 5:00 & Up & No & 81 & 253 \\
\hline 13-Jul & $5: 18$ & Up & Yes & 76 & 254 \\
\hline 13-Jul & $5: 29$ & Up & Yes & 93 & 255 \\
\hline 13-Jul & $5: 40$ & Down & Yes & 100 & 254 \\
\hline 13-Jul & $6: 14$ & Down & Yes & 81 & 253 \\
\hline 13-Jul & 9:34 & Up & Yes & 114 & 254 \\
\hline 13-Jul & $9: 36$ & Up & Yes & 87 & 255 \\
\hline 13-Jul & $9: 36$ & Up & Yes & 78 & 256 \\
\hline 13-Jul & $9: 54$ & $\mathrm{Up}$ & Yes & 76 & 257 \\
\hline 13-Jul & 10:09 & Up & Yes & 75 & 258 \\
\hline 13-Jul & $10: 23$ & Up & Yes & 67 & 259 \\
\hline 13-Jul & $10: 40$ & Up & Yes & 85 & 260 \\
\hline 13-Jul & $10: 46$ & Up & Yes & 94 & 261 \\
\hline 13-Jul & $10: 47$ & $\mathrm{Up}$ & No & 93 & 262 \\
\hline 13-Jul & $10: 59$ & Up & Yes & 76 & 263 \\
\hline 13-Jul & $11: 10$ & Up & Yes & 80 & 264 \\
\hline 13-Jul & $11: 43$ & Up & Yes & 78 & 265 \\
\hline 13-Jul & $11: 43$ & Up & Yes & 78 & 266 \\
\hline 13-Jul & $11: 43$ & Up & Yes & 77 & 267 \\
\hline 13-Jul & $11: 54$ & Up & Yes & 81 & 268 \\
\hline 13-Jul & $18: 19$ & Up & Yes & 76 & 269 \\
\hline 13-Jul & $18: 24$ & Up & Yes & 65 & 270 \\
\hline 13-Jul & $19: 18$ & $\mathrm{Up}$ & Yes & 82 & 271 \\
\hline 13-Jul & $20: 07$ & Up & Yes & 71 & 272 \\
\hline 13-Jul & $20: 21$ & Up & Yes & 85 & 273 \\
\hline 13-Jul & $20: 29$ & Up & No & 89 & 274 \\
\hline 13-Jul & $20: 29$ & Up & Yes & 82 & 275 \\
\hline 13-Jul & $20: 36$ & Up & Yes & 74 & 276 \\
\hline 13-Jul & $20: 42$ & $\mathrm{Up}$ & Yes & 73 & 277 \\
\hline 13-Jul & $22: 47$ & Down & Yes & 78 & 276 \\
\hline 13-Jul & 23:02 & Down & Yes & 68 & 275 \\
\hline
\end{tabular}


Table A-1 (continued)

\begin{tabular}{|c|c|c|c|c|c|}
\hline $\begin{array}{l}\text { Date } \\
(2002)\end{array}$ & $\begin{array}{l}\text { Time } \\
\text { (hours) }\end{array}$ & $\begin{array}{r}\text { Direction } \\
\text { (up/down) }\end{array}$ & $\begin{array}{l}\text { Adipose Fin } \\
\text { (yes/no) }\end{array}$ & $\begin{array}{l}\text { Estimated } \\
\text { Length }(\mathrm{cm})\end{array}$ & $\begin{array}{c}\text { Net Upstream } \\
\text { Movement }\end{array}$ \\
\hline 13-Jul & 23:07 & Down & Yes & $\sim$ & 274 \\
\hline 13-Jul & $23: 10$ & Up & Yes & 85 & 275 \\
\hline 13-Jul & $23: 12$ & Down & Yes & 84 & 274 \\
\hline 14-Jul & $0: 17$ & $\mathrm{Up}$ & Yes & 80 & 275 \\
\hline 14-Jul & $0: 42$ & Up & Yes & 78 & 276 \\
\hline 14-Jul & $1: 47$ & Down & Yes & 67 & 275 \\
\hline 14-Jul & 2:03 & Up & Yes & 104 & 276 \\
\hline 14-Jul & $4: 46$ & Up & Yes & 61 & 277 \\
\hline 14-Jul & $5: 34$ & Down & Yes & 75 & 276 \\
\hline 14-Jul & $5: 59$ & Down & Yes & 89 & 275 \\
\hline 14-Jul & $6: 01$ & Down & Yes & 80 & 274 \\
\hline 14-Jul & 6:08 & Down & Yes & 83 & 273 \\
\hline 14-Jul & $6: 55$ & Up & No & 79 & 274 \\
\hline 14-Jul & $7: 16$ & $\mathrm{Up}$ & Yes & 77 & 275 \\
\hline 14-Jul & $7: 41$ & $\mathrm{Up}$ & Yes & 64 & 276 \\
\hline 14-Jul & $7: 52$ & Up & Yes & 80 & 277 \\
\hline 14-Jul & $8: 01$ & Up & Yes & 84 & 278 \\
\hline 14-Jul & 8:09 & Up & Yes & 76 & 279 \\
\hline 14-Jul & $8: 10$ & Down & Yes & 89 & 278 \\
\hline 14-Jul & $8: 17$ & Up & Yes & 92 & 279 \\
\hline 14-Jul & $8: 41$ & Up & Yes & 68 & 280 \\
\hline 14-Jul & $9: 28$ & Down & Yes & 74 & 279 \\
\hline 14-Jul & $9: 28$ & Up & Yes & 64 & 280 \\
\hline 14-Jul & $9: 29$ & Down & Yes & $\sim$ & 279 \\
\hline 14-Jul & $9: 31$ & Up & Yes & $\sim$ & 280 \\
\hline 14-Jul & $10: 31$ & Up & Yes & 55 & 281 \\
\hline 14-Jul & $10: 41$ & Up & No & $\sim$ & 282 \\
\hline 14-Jul & $10: 46$ & Up & Yes & 72 & 283 \\
\hline 14-Jul & $11: 15$ & Up & Yes & 54 & 284 \\
\hline 14-Jul & $12: 14$ & Up & Yes & 74 & 285 \\
\hline 14-Jul & $12: 35$ & Up & Yes & 77 & 286 \\
\hline 14-Jul & $13: 20$ & $\mathrm{Up}$ & Yes & 70 & 287 \\
\hline 14-Jul & $13: 53$ & Down & Yes & 79 & 286 \\
\hline 14-Jul & $13: 56$ & Up & Yes & 77 & 287 \\
\hline 14-Jul & $15: 17$ & Down & Yes & 76 & 286 \\
\hline 14-Jul & $16: 36$ & Up & Yes & 56 & 287 \\
\hline 14-Jul & $20: 27$ & Up & Yes & 93 & 288 \\
\hline 14-Jul & $21: 23$ & Up & $\sim$ & 83 & 289 \\
\hline 14-Jul & $21: 58$ & Up & Yes & 78 & 290 \\
\hline 14-Jul & 22:01 & Up & Yes & 84 & 291 \\
\hline
\end{tabular}


Table A-1 (continued)

\begin{tabular}{|c|c|c|c|c|c|}
\hline $\begin{array}{l}\text { Date } \\
(2002)\end{array}$ & $\begin{array}{l}\text { Time } \\
\text { (hours) }\end{array}$ & $\begin{array}{l}\text { Direction } \\
\text { (up/down) }\end{array}$ & $\begin{array}{l}\text { Adipose Fin } \\
\text { (yes/no) }\end{array}$ & $\begin{array}{l}\text { Estimated } \\
\text { Length }(\mathrm{cm})\end{array}$ & $\begin{array}{c}\text { Net Upstream } \\
\text { Movement }\end{array}$ \\
\hline 14-Jul & $22: 03$ & Up & Yes & 80 & 292 \\
\hline 14-Jul & $23: 23$ & Up & Yes & 75 & 293 \\
\hline 14-Jul & $23: 27$ & Down & Yes & $\sim$ & 292 \\
\hline 14-Jul & $23: 47$ & $\mathrm{Up}$ & No & 81 & 293 \\
\hline 15-Jul & $0: 23$ & Up & Yes & 74 & 294 \\
\hline 15-Jul & $0: 48$ & Up & Yes & 78 & 295 \\
\hline 15-Jul & $0: 50$ & $\mathrm{Up}$ & $\sim$ & 97 & 296 \\
\hline 15-Jul & $0: 50$ & Down & Yes & 80 & 295 \\
\hline 15-Jul & $0: 50$ & Up & Yes & 87 & 296 \\
\hline 15-Jul & $1: 19$ & Down & $\sim$ & $\sim$ & 295 \\
\hline 15-Jul & $1: 52$ & Up & Yes & $\sim$ & 296 \\
\hline 15-Jul & $3: 30$ & Down & $\sim$ & 82 & 295 \\
\hline 15-Jul & $3: 36$ & $\mathrm{Up}$ & Yes & 85 & 296 \\
\hline 15-Jul & $3: 58$ & Down & $\sim$ & $\sim$ & 295 \\
\hline 15-Jul & 4:09 & Down & $\sim$ & 75 & 294 \\
\hline 15-Jul & $4: 11$ & Up & Yes & $\sim$ & 295 \\
\hline 15-Jul & $4: 30$ & Up & Yes & $\sim$ & 296 \\
\hline 15-Jul & 5:08 & Up & Yes & 86 & 297 \\
\hline 15-Jul & $5: 16$ & Up & Yes & 79 & 298 \\
\hline 15-Jul & $6: 13$ & Up & Yes & 76 & 299 \\
\hline 15-Jul & $6: 13$ & $\mathrm{Up}$ & $\sim$ & 72 & 300 \\
\hline 15-Jul & $6: 19$ & Down & Yes & 104 & 299 \\
\hline 15-Jul & $6: 22$ & Up & Yes & 80 & 300 \\
\hline 15-Jul & $7: 50$ & Up & No & 97 & 301 \\
\hline 15-Jul & $11: 54$ & Up & Yes & 77 & 302 \\
\hline 15-Jul & $12: 00$ & Up & Yes & 78 & 303 \\
\hline 15-Jul & $12: 03$ & $\mathrm{Up}$ & Yes & 84 & 304 \\
\hline 15-Jul & $12: 03$ & Up & Yes & 72 & 305 \\
\hline 15-Jul & 13:08 & Up & Yes & 76 & 306 \\
\hline 15-Jul & $14: 06$ & Up & Yes & 61 & 307 \\
\hline 15-Jul & $17: 27$ & $\mathrm{Up}$ & Yes & 99 & 308 \\
\hline 15-Jul & $21: 58$ & $\mathrm{Up}$ & Yes & 72 & 309 \\
\hline 15-Jul & $22: 15$ & Up & Yes & 52 & 310 \\
\hline 16-Jul & $2: 18$ & $\mathrm{Up}$ & Yes & 89 & 311 \\
\hline 16-Jul & $6: 05$ & Down & Yes & 81 & 310 \\
\hline 16-Jul & $6: 07$ & Up & Yes & 81 & 311 \\
\hline 16-Jul & $6: 08$ & Down & Yes & 86 & 310 \\
\hline 17-Jul & $3: 24$ & Up & Yes & 82 & 311 \\
\hline 17-Jul & \multicolumn{4}{|c|}{ Correction for outage $7 / 17,4: 47$ to $7 / 17,13: 47(+3)$} & 314 \\
\hline 17-Jul & 23:10 & Up & Yes & 79 & 315 \\
\hline
\end{tabular}


Table A-1 (continued)

\begin{tabular}{|c|c|c|c|c|c|}
\hline $\begin{array}{l}\text { Date } \\
(2002)\end{array}$ & $\begin{array}{l}\text { Time } \\
\text { (hours) }\end{array}$ & $\begin{array}{r}\text { Direction } \\
\text { (up/down) }\end{array}$ & $\begin{array}{l}\text { Adipose Fin } \\
\text { (yes/no) }\end{array}$ & $\begin{array}{l}\text { Estimated } \\
\text { Length }(\mathrm{cm})\end{array}$ & $\begin{array}{c}\text { Net Upstream } \\
\text { Movement }\end{array}$ \\
\hline 17-Jul & $23: 23$ & Down & Yes & 79 & 314 \\
\hline 17-Jul & $23: 24$ & Up & Yes & 83 & 315 \\
\hline 17-Jul & $23: 29$ & Down & Yes & 76 & 314 \\
\hline 18-Jul & $2: 58$ & $\mathrm{Up}$ & Yes & 78 & 315 \\
\hline 18-Jul & $4: 22$ & Up & Yes & 69 & 316 \\
\hline 18-Jul & 5:02 & Up & Yes & 75 & 317 \\
\hline 18-Jul & $7: 35$ & $\mathrm{Up}$ & Yes & 79 & 318 \\
\hline 18-Jul & $21: 24$ & Up & $\sim$ & $\sim$ & 319 \\
\hline 19-Jul & $0: 01$ & Down & Yes & 74 & 318 \\
\hline 19-Jul & $0: 11$ & Down & Yes & 74 & 317 \\
\hline 19-Jul & $0: 41$ & Up & Yes & 78 & 318 \\
\hline 19-Jul & $0: 49$ & Up & Yes & 82 & 319 \\
\hline 19-Jul & $1: 10$ & Down & No & 81 & 318 \\
\hline 19-Jul & $1: 30$ & Up & Yes & 83 & 319 \\
\hline 19-Jul & $2: 26$ & Down & Yes & 74 & 318 \\
\hline 19-Jul & $2: 40$ & Up & Yes & 84 & 319 \\
\hline 19-Jul & $10: 53$ & Up & No & 81 & 320 \\
\hline 19-Jul & $22: 24$ & $\mathrm{Up}$ & Yes & 77 & 321 \\
\hline 19-Jul & $22: 31$ & Up & Yes & 84 & 322 \\
\hline 19-Jul & $22: 34$ & $\mathrm{Up}$ & Yes & 88 & 323 \\
\hline 20-Jul & 3:08 & Up & No & 59 & 324 \\
\hline 20-Jul & $3: 28$ & Down & No & 58 & 323 \\
\hline 20-Jul & $3: 35$ & Up & No & 59 & 324 \\
\hline 20-Jul & $23: 40$ & Down & Yes & 79 & 323 \\
\hline 21-Jul & $4: 48$ & Up & Yes & 97 & 324 \\
\hline 22-Jul & $11: 21$ & Up & Yes & 84 & 325 \\
\hline 22-Jul & $11: 31$ & Up & Yes & 81 & 326 \\
\hline 22-Jul & $16: 40$ & Up & Yes & 78 & 327 \\
\hline 23-Jul & 0:01 & Up & Yes & 76 & 328 \\
\hline 23-Jul & 0:01 & Up & Yes & 86 & 329 \\
\hline 23-Jul & 0:02 & Up & Yes & 70 & 330 \\
\hline 23-Jul & $1: 49$ & Down & Yes & $\sim$ & 329 \\
\hline 23-Jul & $2: 21$ & Up & Yes & 84 & 330 \\
\hline 23-Jul & 3:01 & Down & Yes & 87 & 329 \\
\hline 23-Jul & 3:02 & Up & Yes & 81 & 330 \\
\hline 23-Jul & 3:04 & Down & Yes & 80 & 329 \\
\hline 23-Jul & $3: 49$ & Up & Yes & 82 & 330 \\
\hline 23-Jul & 4:05 & Down & Yes & 83 & 329 \\
\hline 23-Jul & $4: 12$ & Up & Yes & 79 & 330 \\
\hline 23-Jul & $4: 14$ & Down & Yes & 82 & 329 \\
\hline
\end{tabular}


Table A-1 (continued)

\begin{tabular}{|c|c|c|c|c|c|}
\hline $\begin{array}{l}\text { Date } \\
(2002)\end{array}$ & $\begin{array}{l}\text { Time } \\
\text { (hours) }\end{array}$ & $\begin{array}{r}\text { Direction } \\
\text { (up/down) }\end{array}$ & $\begin{array}{l}\text { Adipose Fin } \\
\text { (yes/no) }\end{array}$ & $\begin{array}{l}\text { Estimated } \\
\text { Length }(\mathrm{cm})\end{array}$ & $\begin{array}{c}\text { Net Upstream } \\
\text { Movement }\end{array}$ \\
\hline 23-Jul & $4: 23$ & Up & Yes & 82 & 330 \\
\hline 23-Jul & $4: 27$ & Down & Yes & 83 & 329 \\
\hline 23-Jul & $4: 28$ & Up & Yes & 81 & 330 \\
\hline 23-Jul & $4: 28$ & Down & Yes & 77 & 329 \\
\hline 23-Jul & $4: 32$ & Down & Yes & $\sim$ & 328 \\
\hline 24-Jul & 5:11 & Up & Yes & 51 & 329 \\
\hline 24-Jul & $7: 41$ & $\mathrm{Up}$ & Yes & 84 & 330 \\
\hline 24-Jul & $12: 06$ & Up & Yes & $\sim$ & 331 \\
\hline 25-Jul & $0: 43$ & Down & Yes & 79 & 330 \\
\hline 25-Jul & $0: 43$ & Up & Yes & 71 & 331 \\
\hline 25-Jul & $0: 49$ & Up & Yes & 80 & 332 \\
\hline 25-Jul & $0: 54$ & Down & Yes & $\sim$ & 331 \\
\hline 25-Jul & 3:08 & Up & Yes & 67 & 332 \\
\hline 25-Jul & $5: 42$ & Down & Yes & 74 & 331 \\
\hline 25-Jul & $5: 46$ & Up & Yes & 74 & 332 \\
\hline 25-Jul & $5: 54$ & Down & Yes & $\sim$ & 331 \\
\hline 25-Jul & $6: 12$ & Down & Yes & 75 & 330 \\
\hline 25-Jul & $23: 20$ & Up & Yes & 71 & 331 \\
\hline 26-Jul & $0: 41$ & Up & Yes & 82 & 332 \\
\hline 26-Jul & $0: 42$ & $\mathrm{Up}$ & Yes & 83 & 333 \\
\hline 26-Jul & 1:03 & Down & Yes & 56 & 332 \\
\hline 26-Jul & $2: 34$ & Down & Yes & 78 & 331 \\
\hline 26-Jul & $2: 36$ & Up & Yes & 76 & 332 \\
\hline 26-Jul & $2: 41$ & Down & Yes & 75 & 331 \\
\hline 26-Jul & $2: 41$ & Down & Yes & 82 & 330 \\
\hline 26-Jul & 3:06 & Up & Yes & 83 & 331 \\
\hline 26-Jul & 3:07 & Up & Yes & 77 & 332 \\
\hline 26-Jul & 3:08 & Down & Yes & 73 & 331 \\
\hline 26-Jul & $3: 23$ & Up & Yes & 76 & 332 \\
\hline 26-Jul & $3: 37$ & Down & Yes & $\sim$ & 331 \\
\hline 26-Jul & $3: 50$ & Down & Yes & $\sim$ & 330 \\
\hline 26-Jul & 23:09 & Down & Yes & 80 & 329 \\
\hline 26-Jul & $23: 20$ & Up & Yes & 75 & 330 \\
\hline 26-Jul & $23: 22$ & Down & Yes & 75 & 329 \\
\hline 26-Jul & $23: 27$ & Up & Yes & 76 & 330 \\
\hline 26-Jul & $23: 42$ & Down & Yes & 72 & 329 \\
\hline 26-Jul & $23: 45$ & Up & Yes & 72 & 330 \\
\hline 26-Jul & $23: 55$ & Down & Yes & 79 & 329 \\
\hline 27-Jul & $6: 49$ & Up & Yes & 83 & 330 \\
\hline 27-Jul & $20: 35$ & Up & Yes & 82 & 331 \\
\hline
\end{tabular}


Table A-1 (continued)

\begin{tabular}{|c|c|c|c|c|c|}
\hline $\begin{array}{l}\text { Date } \\
(2002)\end{array}$ & $\begin{array}{l}\text { Time } \\
\text { (hours) }\end{array}$ & $\begin{array}{r}\text { Direction } \\
\text { (up/down) }\end{array}$ & $\begin{array}{l}\text { Adipose Fin } \\
\text { (yes/no) }\end{array}$ & $\begin{array}{l}\text { Estimated } \\
\text { Length }(\mathrm{cm})\end{array}$ & $\begin{array}{c}\text { Net Upstream } \\
\text { Movement }\end{array}$ \\
\hline 27-Jul & $20: 37$ & Up & Yes & 82 & 332 \\
\hline 27-Jul & $20: 47$ & Up & Yes & 47 & 333 \\
\hline 27-Jul & 23:03 & Up & Yes & 77 & 334 \\
\hline 28-Jul & 0:08 & Up & Yes & 89 & 335 \\
\hline 28-Jul & $0: 11$ & Down & Yes & $\sim$ & 334 \\
\hline 28-Jul & $1: 30$ & Up & Yes & 69 & 335 \\
\hline 28-Jul & $1: 52$ & $\mathrm{Up}$ & Yes & 75 & 336 \\
\hline 28-Jul & $6: 44$ & Up & Yes & 82 & 337 \\
\hline 28-Jul & $6: 49$ & $\mathrm{Up}$ & No & 86 & 338 \\
\hline 28-Jul & $13: 21$ & Up & Yes & $\sim$ & 339 \\
\hline 29-Jul & $0: 31$ & Up & No & 54 & 340 \\
\hline 29-Jul & 5:03 & Down & Yes & $\sim$ & 339 \\
\hline 29-Jul & $5: 05$ & Up & Yes & 72 & 340 \\
\hline 29-Jul & $5: 08$ & Down & Yes & $\sim$ & 339 \\
\hline 29-Jul & $5: 16$ & Up & Yes & 78 & 340 \\
\hline 30-Jul & $0: 55$ & Up & Yes & 60 & 341 \\
\hline 30-Jul & $4: 42$ & Down & Yes & 75 & 340 \\
\hline 30-Jul & $4: 48$ & Up & Yes & 78 & 341 \\
\hline 30-Jul & $4: 58$ & Down & Yes & 74 & 340 \\
\hline 30-Jul & 5:00 & Up & Yes & 69 & 341 \\
\hline 30-Jul & 5:16 & Down & Yes & 73 & 340 \\
\hline 30-Jul & $22: 18$ & Up & Yes & 83 & 341 \\
\hline 30-Jul & $22: 25$ & Down & Yes & 80 & 340 \\
\hline 30-Jul & $22: 50$ & Up & Yes & 80 & 341 \\
\hline 30-Jul & $23: 59$ & Up & Yes & 75 & 342 \\
\hline 31-Jul & 1:25 & Down & Yes & 78 & 341 \\
\hline 31-Jul & $1: 31$ & Up & Yes & 78 & 342 \\
\hline 31-Jul & $1: 41$ & Down & Yes & 83 & 341 \\
\hline 31-Jul & $1: 47$ & Down & Yes & $\sim$ & 340 \\
\hline 31-Jul & $1: 49$ & Up & Yes & 87 & 341 \\
\hline 31-Jul & $1: 50$ & Down & Yes & 90 & 340 \\
\hline 31-Jul & $1: 52$ & $\mathrm{Up}$ & Yes & 84 & 341 \\
\hline 31-Jul & $1: 55$ & Down & Yes & 82 & 340 \\
\hline 31-Jul & $2: 40$ & Up & Yes & 83 & 341 \\
\hline 31-Jul & $2: 43$ & Up & Yes & 71 & 342 \\
\hline 31-Jul & $5: 18$ & Down & Yes & 81 & 341 \\
\hline 31-Jul & $5: 38$ & Down & Yes & $\sim$ & 340 \\
\hline 31-Jul & $5: 39$ & Up & Yes & 73 & 341 \\
\hline 31-Jul & $6: 00$ & Up & Yes & 88 & 342 \\
\hline 31-Jul & $6: 12$ & Down & Yes & 79 & 341 \\
\hline
\end{tabular}


Table A-1 (continued)

\begin{tabular}{|c|c|c|c|c|c|}
\hline $\begin{array}{l}\text { Date } \\
(2002)\end{array}$ & $\begin{array}{l}\text { Time } \\
\text { (hours) }\end{array}$ & $\begin{array}{r}\text { Direction } \\
\text { (up/down) }\end{array}$ & $\begin{array}{l}\text { Adipose Fin } \\
\text { (yes/no) }\end{array}$ & $\begin{array}{l}\text { Estimated } \\
\text { Length }(\mathrm{cm})\end{array}$ & $\begin{array}{c}\text { Net Upstream } \\
\text { Movement }\end{array}$ \\
\hline 31-Jul & $22: 33$ & Up & Yes & 85 & 342 \\
\hline 31-Jul & 23:03 & Up & Yes & 107 & 343 \\
\hline 1-Aug & $0: 46$ & Down & Yes & $\sim$ & 342 \\
\hline 1-Aug & $0: 58$ & Up & Yes & 83 & 343 \\
\hline 1-Aug & 3:08 & Up & Yes & 94 & 344 \\
\hline 1-Aug & $3: 34$ & Down & Yes & 73 & 343 \\
\hline 1-Aug & $3: 48$ & Up & Yes & 70 & 344 \\
\hline 1-Aug & $9: 28$ & Up & Yes & 76 & 345 \\
\hline 1-Aug & $22: 22$ & Down & Yes & 79 & 344 \\
\hline 2-Aug & $0: 37$ & Up & Yes & 72 & 345 \\
\hline 2-Aug & $2: 40$ & Down & Yes & 76 & 344 \\
\hline 2-Aug & $3: 10$ & Up & Yes & 70 & 345 \\
\hline 2-Aug & $7: 04$ & Up & Yes & 79 & 346 \\
\hline 2-Aug & 9:05 & Down & Yes & 76 & 345 \\
\hline 2-Aug & 9:07 & Up & Yes & 71 & 346 \\
\hline 2-Aug & 9:09 & Down & Yes & 75 & 345 \\
\hline 2-Aug & $16: 12$ & Down & Yes & 67 & 344 \\
\hline 2-Aug & $17: 19$ & Up & Yes & 71 & 345 \\
\hline 2-Aug & $17: 19$ & Up & Yes & 76 & 346 \\
\hline 2-Aug & $17: 21$ & Down & Yes & 75 & 345 \\
\hline 2-Aug & $17: 24$ & Down & Yes & 76 & 344 \\
\hline 2-Aug & $17: 32$ & Up & Yes & 78 & 345 \\
\hline 2-Aug & $17: 54$ & Down & Yes & 76 & 344 \\
\hline 2-Aug & $18: 10$ & Up & Yes & 71 & 345 \\
\hline 2-Aug & $18: 12$ & Down & Yes & 71 & 344 \\
\hline 2-Aug & $21: 41$ & Up & Yes & 80 & 345 \\
\hline 2-Aug & $21: 45$ & Up & Yes & 70 & 346 \\
\hline 2-Aug & $21: 46$ & Up & Yes & 70 & 347 \\
\hline 2-Aug & $21: 54$ & Up & Yes & 72 & 348 \\
\hline 2-Aug & $22: 12$ & Down & Yes & 78 & 347 \\
\hline 2-Aug & $22: 51$ & Up & Yes & 74 & 348 \\
\hline 2-Aug & $22: 54$ & Down & Yes & 75 & 347 \\
\hline 2-Aug & $23: 18$ & Up & Yes & 80 & 348 \\
\hline 2-Aug & $23: 37$ & Up & Yes & 88 & 349 \\
\hline 3-Aug & $0: 33$ & Up & Yes & 87 & 350 \\
\hline 3-Aug & $2: 03$ & Up & Yes & 75 & 351 \\
\hline 3-Aug & $2: 19$ & Down & Yes & 66 & 350 \\
\hline 3-Aug & $2: 23$ & Up & Yes & 73 & 351 \\
\hline 3-Aug & $2: 50$ & Up & Yes & 103 & 352 \\
\hline 3-Aug & $3: 22$ & Up & Yes & 79 & 353 \\
\hline
\end{tabular}


Table A-1 (continued)

\begin{tabular}{|c|c|c|c|c|c|}
\hline $\begin{array}{l}\text { Date } \\
(2002)\end{array}$ & $\begin{array}{l}\text { Time } \\
\text { (hours) }\end{array}$ & $\begin{array}{r}\text { Direction } \\
\text { (up/down) }\end{array}$ & $\begin{array}{l}\text { Adipose Fin } \\
\text { (yes/no) }\end{array}$ & $\begin{array}{c}\text { Estimated } \\
\text { Length }(\mathrm{cm})\end{array}$ & $\begin{array}{c}\text { Net Upstream } \\
\text { Movement }\end{array}$ \\
\hline 3-Aug & $6: 24$ & Down & Yes & 74 & 352 \\
\hline 3-Aug & $20: 48$ & Down & Yes & 72 & 351 \\
\hline 3-Aug & 21:00 & Up & Yes & 74 & 352 \\
\hline 3-Aug & $22: 27$ & $\mathrm{Up}$ & Yes & 75 & 353 \\
\hline 4-Aug & $4: 34$ & Up & Yes & 78 & 354 \\
\hline 4-Aug & $4: 40$ & Up & Yes & 82 & 355 \\
\hline 4-Aug & $5: 11$ & $\mathrm{Up}$ & Yes & 77 & 356 \\
\hline 4-Aug & $8: 26$ & Up & Yes & 77 & 357 \\
\hline 4-Aug & $10: 21$ & $\mathrm{Up}$ & Yes & 76 & 358 \\
\hline 5-Aug & 0:00 & Down & Yes & 71 & 357 \\
\hline 5-Aug & $0: 15$ & Up & Yes & 82 & 358 \\
\hline 5-Aug & $0: 17$ & Down & Yes & 77 & 357 \\
\hline 5-Aug & $0: 22$ & Up & Yes & 73 & 358 \\
\hline 5-Aug & $0: 32$ & Down & Yes & 71 & 357 \\
\hline 5-Aug & $5: 52$ & Up & Yes & 82 & 358 \\
\hline 5-Aug & $6: 00$ & Down & Yes & 83 & 357 \\
\hline 5-Aug & 7:06 & Up & Yes & 81 & 358 \\
\hline 5-Aug & $14: 55$ & Up & Yes & 84 & 359 \\
\hline 5-Aug & $16: 57$ & Down & Yes & 70 & 358 \\
\hline 5-Aug & $17: 06$ & Down & Yes & 78 & 357 \\
\hline 5-Aug & $17: 17$ & Up & Yes & 77 & 358 \\
\hline 5-Aug & $18: 51$ & Down & Yes & 70 & 357 \\
\hline 5-Aug & $18: 54$ & Up & Yes & 78 & 358 \\
\hline 5-Aug & $18: 55$ & Down & Yes & 83 & 357 \\
\hline 5-Aug & $19: 15$ & Down & Yes & 83 & 356 \\
\hline 5-Aug & $19: 20$ & Up & Yes & 82 & 357 \\
\hline 5-Aug & $20: 12$ & Up & Yes & 81 & 358 \\
\hline 5-Aug & 20:19 & Up & Yes & $\sim$ & 359 \\
\hline 5-Aug & $20: 23$ & Up & Yes & 77 & 360 \\
\hline 5-Aug & $20: 51$ & Up & Yes & 76 & 361 \\
\hline 5-Aug & $21: 22$ & Down & Yes & 75 & 360 \\
\hline 5-Aug & $21: 23$ & Down & Yes & 74 & 359 \\
\hline 5-Aug & $21: 30$ & Down & Yes & 74 & 358 \\
\hline 5-Aug & $21: 36$ & Up & Yes & 77 & 359 \\
\hline 5-Aug & $21: 47$ & Up & Yes & 73 & 360 \\
\hline 5-Aug & $22: 21$ & Down & Yes & 71 & 359 \\
\hline 5-Aug & $22: 35$ & Down & Yes & 78 & 358 \\
\hline 5-Aug & $22: 46$ & Up & Yes & 75 & 359 \\
\hline 5-Aug & $22: 47$ & Down & Yes & 78 & 358 \\
\hline 5-Aug & $22: 56$ & Up & Yes & 78 & 359 \\
\hline
\end{tabular}


Table A-1 (continued)

\begin{tabular}{|c|c|c|c|c|c|}
\hline $\begin{array}{l}\text { Date } \\
(2002)\end{array}$ & $\begin{array}{l}\text { Time } \\
\text { (hours) }\end{array}$ & $\begin{array}{r}\text { Direction } \\
\text { (up/down) }\end{array}$ & $\begin{array}{l}\text { Adipose Fin } \\
\text { (yes/no) }\end{array}$ & $\begin{array}{l}\text { Estimated } \\
\text { Length }(\mathrm{cm})\end{array}$ & $\begin{array}{c}\text { Net Upstream } \\
\text { Movement }\end{array}$ \\
\hline 5-Aug & $22: 58$ & Down & Yes & 82 & 358 \\
\hline 5-Aug & 23:03 & Up & Yes & 80 & 359 \\
\hline 5-Aug & $23: 20$ & Down & Yes & $\sim$ & 358 \\
\hline 5-Aug & $23: 27$ & $\mathrm{Up}$ & Yes & 74 & 359 \\
\hline 5-Aug & $23: 32$ & Down & Yes & $\sim$ & 358 \\
\hline 6-Aug & $0: 44$ & Down & Yes & 70 & 357 \\
\hline 6-Aug & $0: 50$ & Up & Yes & 72 & 358 \\
\hline 6-Aug & $1: 59$ & Up & Yes & 74 & 359 \\
\hline 6-Aug & $2: 50$ & Down & Yes & 80 & 358 \\
\hline 6-Aug & $3: 20$ & Up & Yes & 75 & 359 \\
\hline 6-Aug & $3: 23$ & Up & Yes & 83 & 360 \\
\hline 6-Aug & $3: 55$ & Down & No & 55 & 359 \\
\hline 6-Aug & $3: 57$ & Down & Yes & 75 & 358 \\
\hline 6-Aug & $3: 59$ & Up & No & 54 & 359 \\
\hline 6-Aug & 4:04 & Down & No & $\sim$ & 358 \\
\hline 6-Aug & 4:08 & Up & Yes & 76 & 359 \\
\hline 6-Aug & $4: 22$ & Down & Yes & $\sim$ & 358 \\
\hline 6-Aug & $4: 50$ & Down & Yes & 74 & 357 \\
\hline 6-Aug & 5:02 & Up & Yes & 76 & 358 \\
\hline 6-Aug & 8:07 & $\mathrm{Up}$ & Yes & 72 & 359 \\
\hline 6-Aug & $8: 36$ & Down & Yes & 72 & 358 \\
\hline 6-Aug & $12: 26$ & Up & Yes & 74 & 359 \\
\hline 6-Aug & $12: 27$ & Down & Yes & 78 & 358 \\
\hline 6-Aug & $16: 18$ & Down & Yes & 75 & 357 \\
\hline 6-Aug & $17: 38$ & Down & Yes & 79 & 356 \\
\hline 6-Aug & $17: 42$ & Up & Yes & 76 & 357 \\
\hline 6-Aug & $17: 44$ & Down & Yes & $\sim$ & 356 \\
\hline 6-Aug & $17: 44$ & Down & Yes & 87 & 355 \\
\hline 6-Aug & $17: 45$ & Up & Yes & 77 & 356 \\
\hline 6-Aug & $17: 52$ & Up & Yes & 81 & 357 \\
\hline 6-Aug & $18: 06$ & Down & Yes & 77 & 356 \\
\hline 6-Aug & $18: 31$ & Down & Yes & 86 & 355 \\
\hline 6-Aug & $18: 38$ & Up & Yes & 79 & 356 \\
\hline 6-Aug & 20:22 & Up & Yes & 71 & 357 \\
\hline 6-Aug & $21: 53$ & Down & Yes & 80 & 356 \\
\hline 6-Aug & 22:02 & Up & Yes & 78 & 357 \\
\hline 6-Aug & $22: 52$ & Up & Yes & 76 & 358 \\
\hline 6-Aug & $23: 54$ & Up & Yes & 84 & 359 \\
\hline 7-Aug & 0:03 & Up & Yes & 76 & 360 \\
\hline 7-Aug & 0:03 & Up & Yes & 85 & 361 \\
\hline
\end{tabular}


Table A-1 (continued)

\begin{tabular}{|c|c|c|c|c|c|}
\hline $\begin{array}{l}\text { Date } \\
(2002)\end{array}$ & $\begin{array}{l}\text { Time } \\
\text { (hours) }\end{array}$ & $\begin{array}{r}\text { Direction } \\
\text { (up/down) }\end{array}$ & $\begin{array}{l}\text { Adipose Fin } \\
\text { (yes/no) }\end{array}$ & $\begin{array}{c}\text { Estimated } \\
\text { Length }(\mathrm{cm})\end{array}$ & $\begin{array}{c}\text { Net Upstream } \\
\text { Movement }\end{array}$ \\
\hline 7-Aug & $0: 40$ & Down & No & 83 & 360 \\
\hline 7-Aug & $0: 44$ & Down & Yes & 74 & 359 \\
\hline 7-Aug & $0: 45$ & Up & No & 83 & 360 \\
\hline 7-Aug & $0: 48$ & Down & No & 83 & 359 \\
\hline 7-Aug & $0: 51$ & Up & Yes & 74 & 360 \\
\hline 7-Aug & $1: 10$ & Down & Yes & 84 & 359 \\
\hline 7-Aug & $1: 15$ & Up & No & 81 & 360 \\
\hline 7-Aug & $1: 18$ & Down & No & 83 & 359 \\
\hline 7-Aug & $1: 22$ & Up & No & 77 & 360 \\
\hline 7-Aug & $1: 23$ & Up & Yes & 86 & 361 \\
\hline 7-Aug & $1: 28$ & Down & Yes & 87 & 360 \\
\hline 7-Aug & $1: 37$ & Up & Yes & 84 & 361 \\
\hline 7-Aug & 2:07 & Down & Yes & 82 & 360 \\
\hline 7-Aug & $2: 18$ & Up & Yes & 82 & 361 \\
\hline 7-Aug & $2: 32$ & Down & Yes & 84 & 360 \\
\hline 7-Aug & $15: 29$ & Down & Yes & 75 & 359 \\
\hline 7-Aug & $15: 36$ & Up & Yes & 77 & 360 \\
\hline 7-Aug & $15: 38$ & Down & Yes & 80 & 359 \\
\hline 7-Aug & $19: 04$ & Up & Yes & 75 & 360 \\
\hline 7-Aug & $19: 21$ & Down & Yes & 81 & 359 \\
\hline 7-Aug & $19: 23$ & Up & Yes & 75 & 360 \\
\hline 7-Aug & $19: 24$ & Down & Yes & 86 & 359 \\
\hline 7-Aug & $19: 24$ & Down & Yes & 83 & 358 \\
\hline 7-Aug & $19: 24$ & Up & Yes & 73 & 359 \\
\hline 7-Aug & $19: 26$ & Down & Yes & 72 & 358 \\
\hline 7-Aug & $19: 27$ & Down & Yes & 82 & 357 \\
\hline 7-Aug & $19: 28$ & Up & Yes & 82 & 358 \\
\hline 7-Aug & $19: 34$ & Up & Yes & 76 & 359 \\
\hline 7-Aug & 20:01 & Down & Yes & 65 & 358 \\
\hline 7-Aug & $20: 03$ & Up & Yes & 71 & 359 \\
\hline 7-Aug & $21: 31$ & Up & Yes & 78 & 360 \\
\hline 7-Aug & $22: 42$ & Down & Yes & 70 & 359 \\
\hline 7-Aug & 23:07 & Up & Yes & 72 & 360 \\
\hline 8-Aug & $0: 30$ & Up & Yes & 82 & 361 \\
\hline 8-Aug & $0: 50$ & Up & Yes & 81 & 362 \\
\hline 8-Aug & $13: 28$ & Up & Yes & 81 & 363 \\
\hline 8-Aug & $13: 29$ & Down & Yes & 81 & 362 \\
\hline 8-Aug & $13: 31$ & Up & Yes & 73 & 363 \\
\hline 8-Aug & $16: 54$ & Up & Yes & 75 & 364 \\
\hline 8-Aug & $19: 12$ & Down & Yes & 69 & 363 \\
\hline
\end{tabular}


Table A-1 (continued)

\begin{tabular}{|c|c|c|c|c|c|}
\hline $\begin{array}{l}\text { Date } \\
(2002)\end{array}$ & $\begin{array}{l}\text { Time } \\
\text { (hours) }\end{array}$ & $\begin{array}{r}\text { Direction } \\
\text { (up/down) }\end{array}$ & $\begin{array}{l}\text { Adipose Fin } \\
\text { (yes/no) }\end{array}$ & $\begin{array}{l}\text { Estimated } \\
\text { Length }(\mathrm{cm})\end{array}$ & $\begin{array}{c}\text { Net Upstream } \\
\text { Movement }\end{array}$ \\
\hline 8-Aug & $19: 48$ & Up & Yes & 74 & 364 \\
\hline 8-Aug & $19: 53$ & Down & Yes & 70 & 363 \\
\hline 8-Aug & $19: 57$ & Down & Yes & 71 & 362 \\
\hline 8-Aug & $19: 59$ & Up & Yes & 72 & 363 \\
\hline 8-Aug & $20: 05$ & Up & Yes & 70 & 364 \\
\hline 8-Aug & 20:07 & Down & Yes & 66 & 363 \\
\hline 8-Aug & $22: 32$ & Up & Yes & 73 & 364 \\
\hline 8-Aug & $22: 45$ & Up & Yes & 86 & 365 \\
\hline 8-Aug & 23:03 & $\mathrm{Up}$ & Yes & 68 & 366 \\
\hline 8-Aug & 23:04 & Down & Yes & 74 & 365 \\
\hline 8-Aug & $23: 17$ & Up & Yes & 66 & 366 \\
\hline 8-Aug & $23: 20$ & Down & Yes & 66 & 365 \\
\hline 8-Aug & $23: 53$ & Up & Yes & 64 & 366 \\
\hline 9-Aug & 1:38 & Down & Yes & 79 & 365 \\
\hline 9-Aug & $3: 27$ & Up & Yes & 82 & 366 \\
\hline 9-Aug & $9: 51$ & Up & Yes & $\sim$ & 367 \\
\hline 9-Aug & $14: 28$ & Up & Yes & 74 & 368 \\
\hline 9-Aug & $14: 44$ & Up & Yes & 101 & 369 \\
\hline 9-Aug & $14: 46$ & Up & Yes & 72 & 370 \\
\hline 9-Aug & $14: 48$ & Down & Yes & 74 & 369 \\
\hline 9-Aug & $16: 14$ & Up & Yes & 79 & 370 \\
\hline 9-Aug & $17: 21$ & $\mathrm{Up}$ & Yes & 72 & 371 \\
\hline 9-Aug & $18: 50$ & Down & Yes & 72 & 370 \\
\hline 9-Aug & $18: 55$ & Up & Yes & 75 & 371 \\
\hline 9-Aug & $23: 30$ & Up & Yes & 86 & 372 \\
\hline 9-Aug & $23: 35$ & Up & Yes & 77 & 373 \\
\hline 9-Aug & $23: 37$ & Up & Yes & 67 & 374 \\
\hline 9-Aug & $23: 58$ & Up & Yes & 71 & 375 \\
\hline 10-Aug & 0:00 & Down & Yes & 73 & 374 \\
\hline 10-Aug & 0:07 & Up & Yes & 80 & 375 \\
\hline 10-Aug & 0:07 & Up & Yes & 69 & 376 \\
\hline 10-Aug & $0: 18$ & Down & Yes & 69 & 375 \\
\hline 10-Aug & $0: 29$ & Up & Yes & 69 & 376 \\
\hline 10-Aug & $0: 29$ & Up & Yes & 82 & 377 \\
\hline 10-Aug & $0: 32$ & Down & Yes & 78 & 376 \\
\hline 10-Aug & $0: 33$ & Down & Yes & 79 & 375 \\
\hline 10-Aug & $0: 34$ & Up & Yes & 83 & 376 \\
\hline 10-Aug & $0: 48$ & Up & Yes & 74 & 377 \\
\hline 10-Aug & $1: 21$ & Down & Yes & 89 & 376 \\
\hline 10-Aug & $1: 27$ & Up & Yes & 76 & 377 \\
\hline
\end{tabular}


Table A-1 (continued)

\begin{tabular}{|c|c|c|c|c|c|}
\hline $\begin{array}{l}\text { Date } \\
(2002)\end{array}$ & $\begin{array}{l}\text { Time } \\
\text { (hours) }\end{array}$ & $\begin{array}{r}\text { Direction } \\
\text { (up/down) }\end{array}$ & $\begin{array}{l}\text { Adipose Fin } \\
\text { (yes/no) }\end{array}$ & $\begin{array}{l}\text { Estimated } \\
\text { Length }(\mathrm{cm})\end{array}$ & $\begin{array}{c}\text { Net Upstream } \\
\text { Movement }\end{array}$ \\
\hline 10-Aug & $1: 33$ & Up & Yes & 80 & 378 \\
\hline 10-Aug & $1: 36$ & Up & Yes & 79 & 379 \\
\hline 10-Aug & $2: 10$ & Down & Yes & 76 & 378 \\
\hline 10-Aug & $2: 13$ & $\mathrm{Up}$ & Yes & 75 & 379 \\
\hline 10-Aug & $2: 29$ & Up & Yes & 72 & 380 \\
\hline 10-Aug & $2: 30$ & Down & Yes & 79 & 379 \\
\hline 10-Aug & $2: 34$ & Up & Yes & 75 & 380 \\
\hline 10-Aug & $12: 25$ & Up & Yes & 94 & 381 \\
\hline 10-Aug & $14: 34$ & Down & Yes & 72 & 380 \\
\hline 10-Aug & $14: 43$ & Up & Yes & 71 & 381 \\
\hline 10-Aug & $14: 45$ & Down & Yes & 69 & 380 \\
\hline 10-Aug & $14: 47$ & Up & Yes & 69 & 381 \\
\hline 10-Aug & $14: 55$ & Down & Yes & 70 & 380 \\
\hline 10-Aug & $15: 28$ & Up & Yes & 80 & 381 \\
\hline 10-Aug & $15: 28$ & Up & Yes & 77 & 382 \\
\hline 10-Aug & 19:08 & Down & Yes & 74 & 381 \\
\hline 10-Aug & $19: 13$ & Up & Yes & 75 & 382 \\
\hline 10-Aug & $19: 14$ & Down & Yes & 72 & 381 \\
\hline 10-Aug & 20:05 & Up & Yes & 78 & 382 \\
\hline 10-Aug & $20: 16$ & $\mathrm{Up}$ & Yes & 73 & 383 \\
\hline 10-Aug & 20:18 & Up & Yes & 82 & 384 \\
\hline 10-Aug & $20: 39$ & Up & Yes & 85 & 385 \\
\hline 10-Aug & $21: 19$ & Down & Yes & 83 & 384 \\
\hline 10-Aug & $22: 03$ & Down & Yes & 86 & 383 \\
\hline 10-Aug & $22: 07$ & Down & Yes & 76 & 382 \\
\hline 10-Aug & 22:08 & Up & Yes & 74 & 383 \\
\hline 10-Aug & $22: 10$ & Down & Yes & $\sim$ & 382 \\
\hline 10-Aug & $22: 25$ & Up & Yes & 77 & 383 \\
\hline 10-Aug & $22: 26$ & Down & Yes & $\sim$ & 382 \\
\hline 10-Aug & $22: 29$ & Up & Yes & 83 & 383 \\
\hline 10-Aug & $23: 21$ & Up & Yes & 72 & 384 \\
\hline 10-Aug & $23: 33$ & $\mathrm{Up}$ & Yes & 72 & 385 \\
\hline 10-Aug & $23: 43$ & Up & Yes & 79 & 386 \\
\hline 11-Aug & $0: 13$ & Down & Yes & 69 & 385 \\
\hline 11-Aug & $0: 22$ & Up & Yes & 77 & 386 \\
\hline 11-Aug & $2: 30$ & Down & Yes & 81 & 385 \\
\hline 11-Aug & $2: 35$ & Up & Yes & 85 & 386 \\
\hline 11-Aug & $2: 55$ & Down & Yes & 83 & 385 \\
\hline 11-Aug & $2: 57$ & $\mathrm{Up}$ & Yes & 75 & 386 \\
\hline 11-Aug & $3: 14$ & Down & Yes & $\sim$ & 385 \\
\hline
\end{tabular}


Table A-1 (continued)

\begin{tabular}{|c|c|c|c|c|c|}
\hline $\begin{array}{l}\text { Date } \\
(2002)\end{array}$ & $\begin{array}{l}\text { Time } \\
\text { (hours) }\end{array}$ & $\begin{array}{r}\text { Direction } \\
\text { (up/down) }\end{array}$ & $\begin{array}{l}\text { Adipose Fin } \\
\text { (yes/no) }\end{array}$ & $\begin{array}{l}\text { Estimated } \\
\text { Length }(\mathrm{cm})\end{array}$ & $\begin{array}{c}\text { Net Upstream } \\
\text { Movement }\end{array}$ \\
\hline 11-Aug & $5: 39$ & Up & Yes & 73 & 386 \\
\hline 11-Aug & $6: 05$ & Up & Yes & 67 & 387 \\
\hline 11-Aug & $12: 59$ & Down & Yes & 76 & 386 \\
\hline 11-Aug & 14:11 & Up & Yes & 82 & 387 \\
\hline 11-Aug & $17: 06$ & Up & Yes & 81 & 388 \\
\hline 11-Aug & $17: 17$ & Up & Yes & 71 & 389 \\
\hline 11-Aug & $17: 31$ & Down & Yes & 72 & 388 \\
\hline 11-Aug & $17: 34$ & Up & Yes & 72 & 389 \\
\hline 11-Aug & $17: 34$ & $\mathrm{Up}$ & Yes & 75 & 390 \\
\hline 11-Aug & $17: 36$ & Down & Yes & 71 & 389 \\
\hline 11-Aug & $17: 51$ & Down & Yes & 71 & 388 \\
\hline 11-Aug & $17: 56$ & Up & Yes & 74 & 389 \\
\hline 11-Aug & $17: 58$ & Down & Yes & 75 & 388 \\
\hline 11-Aug & 21:02 & Up & Yes & 88 & 389 \\
\hline 11-Aug & $22: 59$ & Up & Yes & 74 & 390 \\
\hline 11-Aug & $23: 31$ & Up & Yes & 83 & 391 \\
\hline 12-Aug & $0: 40$ & Up & Yes & 93 & 392 \\
\hline 12-Aug & $4: 35$ & Down & Yes & 80 & 391 \\
\hline 12-Aug & $4: 38$ & Up & Yes & 76 & 392 \\
\hline 12-Aug & $4: 39$ & Down & Yes & 75 & 391 \\
\hline 12-Aug & $4: 40$ & Up & Yes & 82 & 392 \\
\hline 12-Aug & $4: 40$ & Up & Yes & 86 & 393 \\
\hline 12-Aug & $4: 53$ & Up & Yes & 69 & 394 \\
\hline 12-Aug & $5: 27$ & Up & Yes & 79 & 395 \\
\hline 12-Aug & $15: 40$ & Down & Yes & 82 & 394 \\
\hline 12-Aug & $15: 45$ & Up & Yes & 79 & 395 \\
\hline 12-Aug & $15: 46$ & Down & Yes & 80 & 394 \\
\hline 12-Aug & $16: 50$ & Up & Yes & 76 & 395 \\
\hline 12-Aug & 18:08 & Up & Yes & 73 & 396 \\
\hline 12-Aug & $19: 20$ & Up & Yes & 85 & 397 \\
\hline 12-Aug & $22: 14$ & Down & Yes & 72 & 396 \\
\hline 12-Aug & $22: 21$ & $\mathrm{Up}$ & Yes & 81 & 397 \\
\hline 12-Aug & $22: 22$ & Down & Yes & 83 & 396 \\
\hline 12-Aug & $22: 48$ & Up & Yes & 78 & 397 \\
\hline 12-Aug & $23: 39$ & Down & Yes & 75 & 396 \\
\hline 12-Aug & $23: 45$ & Down & Yes & $\sim$ & 395 \\
\hline 12-Aug & $23: 54$ & Up & Yes & 78 & 396 \\
\hline 13-Aug & $0: 49$ & Down & Yes & 72 & 395 \\
\hline 13-Aug & $1: 42$ & Down & Yes & 76 & 394 \\
\hline 13-Aug & $1: 53$ & Up & Yes & 74 & 395 \\
\hline
\end{tabular}


Table A-1 (continued)

\begin{tabular}{|c|c|c|c|c|c|}
\hline $\begin{array}{l}\text { Date } \\
(2002)\end{array}$ & $\begin{array}{l}\text { Time } \\
\text { (hours) }\end{array}$ & $\begin{array}{r}\text { Direction } \\
\text { (up/down) }\end{array}$ & $\begin{array}{l}\text { Adipose Fin } \\
\text { (yes/no) }\end{array}$ & $\begin{array}{l}\text { Estimated } \\
\text { Length }(\mathrm{cm})\end{array}$ & $\begin{array}{c}\text { Net Upstream } \\
\text { Movement }\end{array}$ \\
\hline 13-Aug & 3:09 & Down & Yes & 73 & 394 \\
\hline 13-Aug & $3: 11$ & Up & Yes & 77 & 395 \\
\hline 13-Aug & $3: 16$ & Down & Yes & 76 & 394 \\
\hline 13-Aug & $3: 19$ & $\mathrm{Up}$ & Yes & 71 & 395 \\
\hline 13-Aug & $3: 23$ & Down & Yes & 69 & 394 \\
\hline 13-Aug & $3: 30$ & Up & Yes & 68 & 395 \\
\hline 13-Aug & $3: 31$ & Down & Yes & $\sim$ & 394 \\
\hline 13-Aug & $3: 32$ & Down & Yes & 71 & 393 \\
\hline 13-Aug & $3: 35$ & Up & Yes & 81 & 394 \\
\hline 13-Aug & $3: 36$ & Down & Yes & 79 & 393 \\
\hline 13-Aug & $3: 40$ & Up & Yes & 80 & 394 \\
\hline 13-Aug & $3: 42$ & Down & Yes & 76 & 393 \\
\hline 13-Aug & $3: 46$ & Up & Yes & 83 & 394 \\
\hline 13-Aug & $4: 42$ & Up & Yes & 77 & 395 \\
\hline 13-Aug & 5:08 & Down & Yes & 73 & 394 \\
\hline 13-Aug & $5: 12$ & Down & Yes & 85 & 393 \\
\hline 13-Aug & $5: 50$ & Up & Yes & 81 & 394 \\
\hline 13-Aug & $6: 10$ & Down & Yes & 85 & 393 \\
\hline 13-Aug & $6: 15$ & Up & Yes & 74 & 394 \\
\hline 13-Aug & $6: 15$ & $\mathrm{Up}$ & Yes & 85 & 395 \\
\hline 13-Aug & $6: 19$ & Up & Yes & 82 & 396 \\
\hline 13-Aug & $6: 26$ & Up & Yes & 87 & 397 \\
\hline 13-Aug & $6: 44$ & Down & Yes & 75 & 396 \\
\hline 13-Aug & $6: 50$ & Up & Yes & 76 & 397 \\
\hline 13-Aug & $7: 18$ & Down & Yes & 72 & 396 \\
\hline 13-Aug & $15: 33$ & Down & Yes & 69 & 395 \\
\hline 13-Aug & $15: 33$ & Up & Yes & 74 & 396 \\
\hline 13-Aug & $15: 34$ & Down & Yes & 71 & 395 \\
\hline 13-Aug & $15: 56$ & Down & Yes & 78 & 394 \\
\hline 13-Aug & $15: 57$ & Down & Yes & 86 & 393 \\
\hline 13-Aug & $16: 01$ & Up & Yes & 84 & 394 \\
\hline 13-Aug & $16: 02$ & Down & Yes & 79 & 393 \\
\hline 13-Aug & $16: 05$ & Up & Yes & 81 & 394 \\
\hline 13-Aug & $16: 08$ & Down & Yes & 80 & 393 \\
\hline 13-Aug & $16: 16$ & Down & Yes & 85 & 392 \\
\hline 13-Aug & $16: 21$ & Up & Yes & 79 & 393 \\
\hline 13-Aug & $16: 21$ & Up & Yes & 79 & 394 \\
\hline 13-Aug & $16: 22$ & Down & Yes & 80 & 393 \\
\hline 13-Aug & $16: 39$ & $\mathrm{Up}$ & Yes & 85 & 394 \\
\hline 13-Aug & $17: 22$ & Up & Yes & 78 & 395 \\
\hline
\end{tabular}


Table A-1 (continued)

\begin{tabular}{|c|c|c|c|c|c|}
\hline $\begin{array}{l}\text { Date } \\
(2002)\end{array}$ & $\begin{array}{l}\text { Time } \\
\text { (hours) }\end{array}$ & $\begin{array}{r}\text { Direction } \\
\text { (up/down) }\end{array}$ & $\begin{array}{l}\text { Adipose Fin } \\
\text { (yes/no) }\end{array}$ & $\begin{array}{l}\text { Estimated } \\
\text { Length }(\mathrm{cm})\end{array}$ & $\begin{array}{c}\text { Net Upstream } \\
\text { Movement }\end{array}$ \\
\hline 13-Aug & $17: 33$ & Down & Yes & 70 & 391 \\
\hline 13-Aug & $17: 37$ & Up & Yes & 76 & 392 \\
\hline 13-Aug & $17: 39$ & Down & Yes & 72 & 391 \\
\hline 13-Aug & $20: 48$ & Up & Yes & 77 & 392 \\
\hline 13-Aug & 21:00 & Up & Yes & 79 & 393 \\
\hline 13-Aug & $22: 27$ & Up & Yes & 89 & 394 \\
\hline 13-Aug & $23: 30$ & Down & Yes & 90 & 393 \\
\hline 13-Aug & $23: 32$ & Up & Yes & 80 & 394 \\
\hline 14-Aug & $0: 48$ & $\mathrm{Up}$ & Yes & 75 & 395 \\
\hline 14-Aug & $3: 17$ & Up & Yes & 76 & 396 \\
\hline 14-Aug & $3: 37$ & $\mathrm{Up}$ & Yes & 79 & 397 \\
\hline 14-Aug & $3: 41$ & Down & Yes & $\sim$ & 396 \\
\hline 14-Aug & $3: 44$ & Up & Yes & 78 & 397 \\
\hline 14-Aug & $4: 45$ & Down & Yes & 75 & 396 \\
\hline 14-Aug & $4: 49$ & Up & Yes & 82 & 397 \\
\hline 14-Aug & $6: 06$ & Up & Yes & 94 & 398 \\
\hline 14-Aug & $13: 38$ & Down & Yes & 74 & 397 \\
\hline 14-Aug & $13: 41$ & Down & Yes & 71 & 396 \\
\hline 14-Aug & $13: 45$ & Down & Yes & 75 & 395 \\
\hline 14-Aug & $13: 49$ & Up & Yes & $\sim$ & 396 \\
\hline 14-Aug & $13: 52$ & Down & Yes & 75 & 395 \\
\hline 14-Aug & $14: 04$ & Up & Yes & 83 & 396 \\
\hline 14-Aug & $14: 05$ & Down & Yes & 86 & 395 \\
\hline 14-Aug & $14: 45$ & Down & Yes & 85 & 394 \\
\hline 14-Aug & $16: 01$ & Up & Yes & 85 & 395 \\
\hline 14-Aug & $16: 01$ & Up & Yes & 81 & 396 \\
\hline 14-Aug & $16: 10$ & Up & Yes & 86 & 397 \\
\hline 14-Aug & $16: 17$ & Down & Yes & 81 & 396 \\
\hline 14-Aug & $16: 26$ & Up & Yes & 81 & 397 \\
\hline 14-Aug & $16: 49$ & Up & No & 79 & 398 \\
\hline 14-Aug & $17: 27$ & Down & Yes & 83 & 397 \\
\hline 14-Aug & $17: 58$ & $\mathrm{Up}$ & Yes & 86 & 398 \\
\hline 14-Aug & $18: 30$ & Down & Yes & 74 & 397 \\
\hline 14-Aug & $18: 30$ & Down & Yes & 83 & 396 \\
\hline 14-Aug & $18: 50$ & Up & Yes & 81 & 397 \\
\hline 14-Aug & $18: 58$ & Down & Yes & 92 & 396 \\
\hline 14-Aug & $19: 03$ & Up & Yes & 84 & 397 \\
\hline 14-Aug & $19: 41$ & Up & Yes & 78 & 398 \\
\hline 14-Aug & $19: 55$ & Down & Yes & 69 & 397 \\
\hline 14-Aug & $23: 18$ & Down & Yes & 67 & 396 \\
\hline
\end{tabular}


Table A-1 (continued)

\begin{tabular}{|c|c|c|c|c|c|}
\hline $\begin{array}{l}\text { Date } \\
(2002)\end{array}$ & $\begin{array}{l}\text { Time } \\
\text { (hours) }\end{array}$ & $\begin{array}{r}\text { Direction } \\
\text { (up/down) }\end{array}$ & $\begin{array}{l}\text { Adipose Fin } \\
\text { (yes/no) }\end{array}$ & $\begin{array}{c}\text { Estimated } \\
\text { Length }(\mathrm{cm})\end{array}$ & $\begin{array}{c}\text { Net Upstream } \\
\text { Movement }\end{array}$ \\
\hline 14-Aug & $23: 26$ & Up & No & 76 & 397 \\
\hline 14-Aug & $23: 33$ & Up & Yes & 72 & 398 \\
\hline 14-Aug & $23: 37$ & Up & Yes & 78 & 399 \\
\hline 14-Aug & $23: 42$ & Down & No & 90 & 398 \\
\hline 14-Aug & $23: 46$ & Down & Yes & 75 & 397 \\
\hline 14-Aug & $23: 50$ & Down & Yes & $\sim$ & 396 \\
\hline 14-Aug & $23: 53$ & Up & No & 79 & 397 \\
\hline 14-Aug & $23: 55$ & Up & Yes & 85 & 398 \\
\hline 14-Aug & $23: 57$ & Down & No & 73 & 397 \\
\hline 14-Aug & $23: 58$ & Down & Yes & $\sim$ & 396 \\
\hline 15-Aug & 0:01 & Up & No & 79 & 397 \\
\hline 15-Aug & 0:03 & Down & No & 79 & 396 \\
\hline 15-Aug & 0:09 & Up & No & 79 & 397 \\
\hline 15-Aug & $0: 14$ & Down & No & 80 & 396 \\
\hline 15-Aug & $1: 10$ & Up & Yes & 81 & 397 \\
\hline 15-Aug & $1: 32$ & Down & Yes & 84 & 396 \\
\hline 15-Aug & $1: 51$ & Down & Yes & 74 & 395 \\
\hline 15-Aug & $3: 58$ & Down & Yes & 76 & 394 \\
\hline 15-Aug & 4:07 & Up & Yes & 83 & 395 \\
\hline 15-Aug & 4:19 & Down & Yes & 83 & 394 \\
\hline 15-Aug & $4: 26$ & Up & Yes & 79 & 395 \\
\hline 15-Aug & $4: 38$ & Up & No & 83 & 396 \\
\hline 15-Aug & $4: 45$ & Down & No & 78 & 395 \\
\hline 15-Aug & $4: 53$ & Up & No & 71 & 396 \\
\hline 15-Aug & $4: 56$ & Down & No & 76 & 395 \\
\hline 15-Aug & $5: 05$ & Up & No & $\sim$ & 396 \\
\hline 15-Aug & 5:09 & Down & No & $\sim$ & 395 \\
\hline 15-Aug & $6: 11$ & Up & Yes & 108 & 396 \\
\hline 15-Aug & $6: 11$ & Up & Yes & 79 & 397 \\
\hline 15-Aug & $8: 43$ & Down & Yes & 78 & 396 \\
\hline 15-Aug & $8: 44$ & Up & Yes & 76 & 397 \\
\hline 15-Aug & $8: 46$ & Down & Yes & 78 & 396 \\
\hline 15-Aug & $9: 16$ & Up & Yes & 80 & 397 \\
\hline 15-Aug & $9: 20$ & Down & Yes & 79 & 396 \\
\hline 15-Aug & $9: 43$ & Up & Yes & 78 & 397 \\
\hline 15-Aug & $12: 18$ & Up & No & 78 & 398 \\
\hline 15-Aug & $12: 19$ & Up & Yes & 88 & 399 \\
\hline 15-Aug & $13: 24$ & Down & No & 73 & 398 \\
\hline 15-Aug & $13: 29$ & Down & Yes & 78 & 397 \\
\hline 15-Aug & $13: 31$ & Up & Yes & 75 & 398 \\
\hline
\end{tabular}


Table A-1 (continued)

\begin{tabular}{|c|c|c|c|c|c|}
\hline $\begin{array}{l}\text { Date } \\
(2002)\end{array}$ & $\begin{array}{l}\text { Time } \\
\text { (hours) }\end{array}$ & $\begin{array}{r}\text { Direction } \\
\text { (up/down) }\end{array}$ & $\begin{array}{l}\text { Adipose Fin } \\
\text { (yes/no) }\end{array}$ & $\begin{array}{l}\text { Estimated } \\
\text { Length }(\mathrm{cm})\end{array}$ & $\begin{array}{c}\text { Net Upstream } \\
\text { Movement }\end{array}$ \\
\hline 15-Aug & $14: 57$ & Up & Yes & 85 & 399 \\
\hline 15-Aug & $16: 04$ & Up & Yes & 83 & 400 \\
\hline 15-Aug & $16: 08$ & Down & Yes & 74 & 399 \\
\hline 15-Aug & $16: 10$ & $\mathrm{Up}$ & Yes & 83 & 400 \\
\hline 15-Aug & $16: 30$ & Down & Yes & 81 & 399 \\
\hline 15-Aug & $16: 34$ & Up & Yes & 73 & 400 \\
\hline 15-Aug & $16: 43$ & Down & Yes & $\sim$ & 399 \\
\hline 15-Aug & $18: 21$ & Up & Yes & 82 & 400 \\
\hline 15-Aug & $19: 39$ & $\mathrm{Up}$ & Yes & 83 & 401 \\
\hline 15-Aug & $19: 42$ & Down & Yes & 88 & 400 \\
\hline 15-Aug & $20: 05$ & Up & Yes & 86 & 401 \\
\hline 15-Aug & 20:12 & Down & Yes & 83 & 400 \\
\hline 15-Aug & $23: 18$ & Up & Yes & 62 & 401 \\
\hline 15-Aug & $23: 42$ & Down & Yes & 83 & 400 \\
\hline 15-Aug & $23: 45$ & Up & Yes & 83 & 401 \\
\hline 16-Aug & $2: 18$ & Down & Yes & 86 & 400 \\
\hline 16-Aug & $2: 19$ & Down & Yes & 76 & 399 \\
\hline 16-Aug & $2: 20$ & Up & Yes & 81 & 400 \\
\hline 16-Aug & $2: 23$ & Down & Yes & 76 & 399 \\
\hline 16-Aug & $2: 29$ & Up & Yes & 77 & 400 \\
\hline 16-Aug & $4: 46$ & Down & Yes & 80 & 399 \\
\hline 16-Aug & $4: 51$ & Up & Yes & 76 & 400 \\
\hline 16-Aug & 8:09 & Down & Yes & 75 & 399 \\
\hline 16-Aug & $8: 16$ & Down & Yes & 80 & 398 \\
\hline 16-Aug & $8: 18$ & Up & Yes & 75 & 399 \\
\hline 16-Aug & $8: 18$ & Up & Yes & 80 & 400 \\
\hline 16-Aug & $8: 19$ & Down & Yes & 80 & 399 \\
\hline 16-Aug & $8: 22$ & Down & Yes & 75 & 398 \\
\hline 16-Aug & $8: 23$ & Up & Yes & 80 & 399 \\
\hline 16-Aug & $8: 23$ & Up & Yes & 75 & 400 \\
\hline 16-Aug & $9: 21$ & Down & Yes & 80 & 399 \\
\hline 16-Aug & $9: 30$ & $\mathrm{Up}$ & Yes & 80 & 400 \\
\hline 16-Aug & $9: 33$ & Down & Yes & 80 & 399 \\
\hline 16-Aug & $9: 36$ & Up & Yes & 80 & 400 \\
\hline 16-Aug & $9: 38$ & Up & Yes & 80 & 401 \\
\hline 16-Aug & $10: 53$ & Down & Yes & 80 & 400 \\
\hline 16-Aug & $10: 58$ & Up & Yes & 80 & 401 \\
\hline 16-Aug & $10: 59$ & Down & Yes & 80 & 400 \\
\hline 16-Aug & 11:02 & Up & Yes & 80 & 401 \\
\hline 16-Aug & 11:39 & Down & Yes & 80 & 400 \\
\hline
\end{tabular}


Table A-1 (continued)

\begin{tabular}{|c|c|c|c|c|c|}
\hline $\begin{array}{l}\text { Date } \\
(2002)\end{array}$ & $\begin{array}{l}\text { Time } \\
\text { (hours) }\end{array}$ & $\begin{array}{r}\text { Direction } \\
\text { (up/down) }\end{array}$ & $\begin{array}{l}\text { Adipose Fin } \\
\text { (yes/no) }\end{array}$ & $\begin{array}{l}\text { Estimated } \\
\text { Length }(\mathrm{cm})\end{array}$ & $\begin{array}{c}\text { Net Upstream } \\
\text { Movement }\end{array}$ \\
\hline 16-Aug & $13: 27$ & Down & Yes & 80 & 399 \\
\hline 16-Aug & $13: 37$ & Down & Yes & 75 & 398 \\
\hline 16-Aug & $14: 45$ & Down & Yes & 75 & 397 \\
\hline 16-Aug & $14: 53$ & Down & Yes & 80 & 396 \\
\hline 16-Aug & $14: 56$ & Up & Yes & 80 & 397 \\
\hline 16-Aug & $15: 21$ & Down & Yes & 80 & 396 \\
\hline 16-Aug & $15: 49$ & Up & Yes & 80 & 397 \\
\hline 16-Aug & $15: 49$ & Up & Yes & 85 & 398 \\
\hline 16-Aug & $15: 51$ & Down & Yes & 80 & 397 \\
\hline 16-Aug & $15: 56$ & Down & Yes & 85 & 396 \\
\hline 16-Aug & $16: 26$ & Up & Yes & 80 & 397 \\
\hline 16-Aug & $16: 33$ & Down & Yes & 80 & 396 \\
\hline 16-Aug & $17: 14$ & Up & Yes & 70 & 397 \\
\hline 16-Aug & $17: 14$ & Up & Yes & 85 & 398 \\
\hline 16-Aug & $17: 14$ & Down & Yes & 85 & 397 \\
\hline 16-Aug & $17: 32$ & Up & Yes & 85 & 398 \\
\hline 16-Aug & $17: 44$ & Down & Yes & 85 & 397 \\
\hline 16-Aug & $18: 16$ & Up & Yes & 80 & 398 \\
\hline 16-Aug & $19: 19$ & Down & Yes & 75 & 397 \\
\hline 16-Aug & $19: 24$ & Up & No & 80 & 398 \\
\hline 16-Aug & $19: 31$ & Up & Yes & 85 & 399 \\
\hline 16-Aug & $19: 40$ & Down & No & 80 & 398 \\
\hline 16-Aug & $19: 54$ & Down & Yes & 85 & 397 \\
\hline 16-Aug & $20: 00$ & Up & Yes & 75 & 398 \\
\hline 16-Aug & $20: 14$ & Down & Yes & 80 & 397 \\
\hline 16-Aug & 22:02 & Up & Yes & 85 & 398 \\
\hline 17-Aug & $0: 15$ & Up & Yes & 80 & 399 \\
\hline 17-Aug & 1:01 & Down & Yes & 80 & 398 \\
\hline 17-Aug & 1:04 & Down & Yes & 85 & 397 \\
\hline 17-Aug & $1: 18$ & Down & Yes & 80 & 396 \\
\hline 17-Aug & $1: 30$ & Down & Yes & 75 & 395 \\
\hline 17-Aug & $1: 53$ & $\mathrm{Up}$ & Yes & 80 & 396 \\
\hline 17-Aug & $2: 24$ & Down & Yes & 75 & 395 \\
\hline 17-Aug & $2: 35$ & Up & Yes & 75 & 396 \\
\hline 17-Aug & $2: 42$ & Down & Yes & 75 & 395 \\
\hline 17-Aug & $2: 43$ & Up & Yes & 85 & 396 \\
\hline 17-Aug & 3:00 & Up & Yes & 75 & 397 \\
\hline 17-Aug & 3:02 & Down & Yes & 75 & 396 \\
\hline 17-Aug & $3: 35$ & Down & Yes & & 395 \\
\hline 17-Aug & $3: 36$ & Down & Yes & 75 & 394 \\
\hline
\end{tabular}


Table A-1 (continued)

\begin{tabular}{|c|c|c|c|c|c|}
\hline $\begin{array}{l}\text { Date } \\
(2002)\end{array}$ & $\begin{array}{l}\text { Time } \\
\text { (hours) }\end{array}$ & $\begin{array}{r}\text { Direction } \\
\text { (up/down) }\end{array}$ & $\begin{array}{l}\text { Adipose Fin } \\
\text { (yes/no) }\end{array}$ & $\begin{array}{l}\text { Estimated } \\
\text { Length }(\mathrm{cm})\end{array}$ & $\begin{array}{c}\text { Net Upstream } \\
\text { Movement }\end{array}$ \\
\hline 17-Aug & $6: 10$ & Up & Yes & 80 & 395 \\
\hline 17-Aug & $6: 12$ & Up & Yes & 85 & 396 \\
\hline 17-Aug & $6: 15$ & Up & Yes & 80 & 397 \\
\hline 17-Aug & $6: 22$ & Down & Yes & 80 & 396 \\
\hline 17-Aug & $7: 54$ & Up & Yes & 80 & 397 \\
\hline 17-Aug & $11: 30$ & Up & Yes & 75 & 398 \\
\hline 17-Aug & $14: 45$ & Up & Yes & 80 & 399 \\
\hline 17-Aug & $15: 02$ & Down & Yes & 80 & 398 \\
\hline 17-Aug & $15: 32$ & Up & Yes & 80 & 399 \\
\hline 17-Aug & $16: 35$ & Down & Yes & 80 & 398 \\
\hline 17-Aug & $17: 43$ & Up & Yes & 80 & 399 \\
\hline 17-Aug & $17: 45$ & Down & Yes & 80 & 398 \\
\hline 17-Aug & $18: 02$ & Up & Yes & 80 & 399 \\
\hline 17-Aug & 18:03 & Up & Yes & 85 & 400 \\
\hline 17-Aug & $18: 18$ & Down & No & 80 & 399 \\
\hline 17-Aug & $18: 21$ & Up & No & 80 & 400 \\
\hline 17-Aug & $18: 22$ & Down & No & 80 & 399 \\
\hline 17-Aug & $18: 26$ & Down & Yes & 85 & 398 \\
\hline 17-Aug & $18: 27$ & Down & Yes & 80 & 397 \\
\hline 17-Aug & $19: 25$ & Up & Yes & 80 & 398 \\
\hline 17-Aug & $19: 30$ & Up & Yes & 85 & 399 \\
\hline 17-Aug & $19: 43$ & Down & Yes & 80 & 398 \\
\hline 17-Aug & $20: 54$ & Down & Yes & 80 & 397 \\
\hline 17-Aug & $21: 27$ & Up & Yes & 75 & 398 \\
\hline 18-Aug & $2: 20$ & Up & No & 80 & 399 \\
\hline 18-Aug & $2: 30$ & Down & No & 80 & 398 \\
\hline 18-Aug & $2: 34$ & Up & No & 80 & 399 \\
\hline 18-Aug & $3: 19$ & Up & Yes & 85 & 400 \\
\hline 18-Aug & $3: 22$ & Up & No & 75 & 401 \\
\hline 18-Aug & $3: 29$ & Up & Yes & 75 & 402 \\
\hline 18-Aug & $5: 30$ & Up & Yes & 70 & 403 \\
\hline 18-Aug & $5: 57$ & $\mathrm{Up}$ & Yes & 75 & 404 \\
\hline 18-Aug & $6: 16$ & Up & Yes & 80 & 405 \\
\hline 18-Aug & $7: 15$ & Up & Yes & 80 & 406 \\
\hline 18-Aug & $7: 16$ & Down & Yes & 80 & 405 \\
\hline 18-Aug & $7: 24$ & Up & Yes & 80 & 406 \\
\hline 18-Aug & $7: 25$ & Down & Yes & 80 & 405 \\
\hline 18-Aug & $7: 26$ & Up & Yes & 80 & 406 \\
\hline 18-Aug & $7: 28$ & Down & Yes & 80 & 405 \\
\hline 18-Aug & $7: 32$ & Up & Yes & 80 & 406 \\
\hline
\end{tabular}


Table A-1 (continued)

\begin{tabular}{|c|c|c|c|c|c|}
\hline $\begin{array}{l}\text { Date } \\
(2002)\end{array}$ & $\begin{array}{l}\text { Time } \\
\text { (hours) }\end{array}$ & $\begin{array}{r}\text { Direction } \\
\text { (up/down) }\end{array}$ & $\begin{array}{l}\text { Adipose Fin } \\
\text { (yes/no) }\end{array}$ & $\begin{array}{l}\text { Estimated } \\
\text { Length }(\mathrm{cm})\end{array}$ & $\begin{array}{c}\text { Net Upstream } \\
\text { Movement }\end{array}$ \\
\hline 18-Aug & $7: 33$ & Down & Yes & 80 & 405 \\
\hline 18-Aug & $8: 29$ & Down & Yes & 75 & 404 \\
\hline 18-Aug & $8: 42$ & Up & Yes & 80 & 405 \\
\hline 18-Aug & $8: 49$ & Down & Yes & 80 & 404 \\
\hline 18-Aug & $9: 26$ & Up & Yes & 85 & 405 \\
\hline 18-Aug & $10: 21$ & Down & Yes & 85 & 404 \\
\hline 18-Aug & $10: 47$ & Up & No & 85 & 405 \\
\hline 18-Aug & $10: 49$ & Down & No & 80 & 404 \\
\hline 18-Aug & $10: 52$ & Up & No & 80 & 405 \\
\hline 18-Aug & $13: 10$ & Down & Yes & 70 & 404 \\
\hline 18-Aug & $13: 21$ & Down & No & 80 & 403 \\
\hline 18-Aug & $13: 22$ & Up & No & 80 & 404 \\
\hline 18-Aug & $13: 23$ & Down & No & 80 & 403 \\
\hline 18-Aug & $13: 26$ & Up & No & 80 & 404 \\
\hline 18-Aug & $13: 26$ & Up & Yes & 80 & 405 \\
\hline 18-Aug & $13: 28$ & Down & No & 80 & 404 \\
\hline 18-Aug & $13: 28$ & Down & No & 80 & 403 \\
\hline 18-Aug & $13: 31$ & Up & No & 80 & 404 \\
\hline 18-Aug & $13: 32$ & Down & No & 80 & 403 \\
\hline 18-Aug & $14: 16$ & Up & Yes & 75 & 404 \\
\hline 18-Aug & $14: 18$ & Down & Yes & 80 & 403 \\
\hline 18-Aug & $14: 22$ & Down & Yes & 75 & 402 \\
\hline 18-Aug & $14: 27$ & Up & Yes & 75 & 403 \\
\hline 18-Aug & $16: 20$ & Down & Yes & 80 & 402 \\
\hline 18-Aug & $16: 23$ & Up & Yes & 80 & 403 \\
\hline 18-Aug & $16: 39$ & Down & Yes & 80 & 402 \\
\hline 18-Aug & $16: 55$ & Down & Yes & 80 & 401 \\
\hline 18-Aug & $16: 56$ & Up & Yes & 75 & 402 \\
\hline 18-Aug & $17: 20$ & Down & Yes & 75 & 401 \\
\hline 18-Aug & $17: 23$ & Up & Yes & 80 & 402 \\
\hline 18-Aug & $18: 17$ & Up & No & 80 & 403 \\
\hline 18-Aug & $18: 48$ & $\mathrm{Up}$ & Yes & 80 & 404 \\
\hline 18-Aug & $18: 50$ & Down & Yes & 80 & 403 \\
\hline 18-Aug & $18: 56$ & Up & Yes & 80 & 404 \\
\hline 18-Aug & $19: 17$ & Up & Yes & 90 & 405 \\
\hline 18-Aug & $20: 17$ & Up & Yes & 80 & 406 \\
\hline 18-Aug & $20: 35$ & $\mathrm{Up}$ & Yes & 80 & 407 \\
\hline 18-Aug & $21: 10$ & Down & Yes & 80 & 406 \\
\hline 18-Aug & $21: 31$ & Up & Yes & 75 & 407 \\
\hline 18-Aug & $23: 27$ & Down & Yes & 80 & 406 \\
\hline
\end{tabular}


Table A-1 (continued)

\begin{tabular}{|c|c|c|c|c|c|}
\hline $\begin{array}{l}\text { Date } \\
(2002)\end{array}$ & $\begin{array}{l}\text { Time } \\
\text { (hours) }\end{array}$ & $\begin{array}{r}\text { Direction } \\
\text { (up/down) }\end{array}$ & $\begin{array}{l}\text { Adipose Fin } \\
\text { (yes/no) }\end{array}$ & $\begin{array}{l}\text { Estimated } \\
\text { Length }(\mathrm{cm})\end{array}$ & $\begin{array}{c}\text { Net Upstream } \\
\text { Movement }\end{array}$ \\
\hline 18-Aug & $23: 29$ & Up & Yes & 80 & 407 \\
\hline 19-Aug & 0:07 & Up & Yes & 70 & 408 \\
\hline 19-Aug & $0: 19$ & Down & Yes & 70 & 407 \\
\hline 19-Aug & $0: 39$ & $\mathrm{Up}$ & Yes & 80 & 408 \\
\hline 19-Aug & $0: 46$ & Up & No & 80 & 409 \\
\hline 19-Aug & 1:08 & Down & Yes & 70 & 408 \\
\hline 19-Aug & $4: 35$ & Up & Yes & 75 & 409 \\
\hline 19-Aug & $5: 05$ & Up & Yes & 80 & 410 \\
\hline 19-Aug & $5: 50$ & Down & Yes & 80 & 409 \\
\hline 19-Aug & $6: 35$ & Up & Yes & 80 & 410 \\
\hline 19-Aug & 8:07 & Down & Yes & 80 & 409 \\
\hline 19-Aug & $11: 53$ & Down & Yes & 80 & 408 \\
\hline 19-Aug & $12: 19$ & Up & Yes & 80 & 409 \\
\hline 19-Aug & $12: 33$ & Down & Yes & 80 & 408 \\
\hline 19-Aug & $12: 56$ & Up & Yes & 80 & 409 \\
\hline 19-Aug & 13:03 & Up & Yes & 80 & 410 \\
\hline 19-Aug & $13: 29$ & Down & Yes & 80 & 409 \\
\hline 19-Aug & $13: 41$ & Down & Yes & 75 & 408 \\
\hline 19-Aug & 14:08 & Up & Yes & 80 & 409 \\
\hline 19-Aug & $14: 09$ & Down & Yes & 80 & 408 \\
\hline 19-Aug & 14:09 & Down & Yes & 80 & 407 \\
\hline 19-Aug & $14: 09$ & Up & Yes & 80 & 408 \\
\hline 19-Aug & $14: 28$ & Up & Yes & 80 & 409 \\
\hline 19-Aug & $14: 38$ & Down & Yes & 80 & 408 \\
\hline 19-Aug & $15: 10$ & Down & Yes & 80 & 407 \\
\hline 19-Aug & $15: 29$ & Down & No & 75 & 406 \\
\hline 19-Aug & $16: 30$ & Up & No & 80 & 407 \\
\hline 19-Aug & 19:01 & Up & Yes & 80 & 408 \\
\hline 19-Aug & $19: 16$ & Down & Yes & 80 & 407 \\
\hline 19-Aug & $19: 24$ & Up & Yes & 80 & 408 \\
\hline 19-Aug & $19: 26$ & Down & Yes & 80 & 407 \\
\hline 19-Aug & $19: 30$ & $\mathrm{Up}$ & Yes & 80 & 408 \\
\hline 19-Aug & $19: 47$ & Up & Yes & 80 & 409 \\
\hline 19-Aug & $19: 58$ & Down & Yes & 75 & 408 \\
\hline 19-Aug & $19: 58$ & Down & Yes & 75 & 407 \\
\hline 19-Aug & $20: 25$ & Up & Yes & 80 & 408 \\
\hline 19-Aug & $20: 46$ & Down & Yes & 80 & 407 \\
\hline 19-Aug & 21:00 & Down & No & 75 & 406 \\
\hline 20-Aug & 2:08 & $\mathrm{Up}$ & Yes & 55 & 407 \\
\hline 20-Aug & $2: 17$ & Down & Yes & 55 & 406 \\
\hline
\end{tabular}


Table A-1 (continued)

\begin{tabular}{|c|c|c|c|c|c|}
\hline $\begin{array}{l}\text { Date } \\
(2002)\end{array}$ & $\begin{array}{l}\text { Time } \\
\text { (hours) }\end{array}$ & $\begin{array}{r}\text { Direction } \\
\text { (up/down) }\end{array}$ & $\begin{array}{l}\text { Adipose Fin } \\
\text { (yes/no) }\end{array}$ & $\begin{array}{l}\text { Estimated } \\
\text { Length }(\mathrm{cm})\end{array}$ & $\begin{array}{c}\text { Net Upstream } \\
\text { Movement }\end{array}$ \\
\hline 20-Aug & $2: 53$ & Up & Yes & 80 & 407 \\
\hline 20-Aug & 4:08 & Down & Yes & 80 & 406 \\
\hline 20-Aug & $4: 27$ & Down & Yes & 80 & 405 \\
\hline 20-Aug & $4: 43$ & Up & Yes & 80 & 406 \\
\hline 20-Aug & $6: 34$ & Down & Yes & 80 & 405 \\
\hline 20-Aug & $6: 49$ & Up & Yes & 80 & 406 \\
\hline 20-Aug & $6: 54$ & Down & Yes & 80 & 405 \\
\hline 20-Aug & $6: 59$ & Up & Yes & 80 & 406 \\
\hline 20-Aug & $7: 17$ & Down & Yes & 80 & 405 \\
\hline 20-Aug & 8:09 & Down & Yes & 80 & 404 \\
\hline 20-Aug & $8: 39$ & Up & Yes & 80 & 405 \\
\hline 20-Aug & $8: 43$ & Down & Yes & 80 & 404 \\
\hline 20-Aug & $10: 41$ & Up & Yes & 80 & 405 \\
\hline 20-Aug & $12: 58$ & Down & Yes & 80 & 404 \\
\hline 20-Aug & $14: 48$ & Up & Yes & 80 & 405 \\
\hline 20-Aug & $16: 24$ & Down & Yes & 80 & 404 \\
\hline 20-Aug & $16: 26$ & Up & Yes & 80 & 405 \\
\hline 20-Aug & $17: 10$ & Down & Yes & 80 & 404 \\
\hline 20-Aug & 17:11 & Up & Yes & 75 & 405 \\
\hline 20-Aug & $17: 17$ & $\mathrm{Up}$ & Yes & 80 & 406 \\
\hline 20-Aug & $17: 33$ & Down & Yes & 80 & 405 \\
\hline 20-Aug & $17: 33$ & Up & Yes & 80 & 406 \\
\hline 20-Aug & $18: 59$ & Up & Yes & 80 & 407 \\
\hline 20-Aug & $19: 23$ & Down & Yes & 70 & 406 \\
\hline 20-Aug & $20: 32$ & Down & Yes & 80 & 405 \\
\hline 20-Aug & $20: 56$ & Up & Yes & 80 & 406 \\
\hline 20-Aug & $21: 13$ & Up & Yes & 80 & 407 \\
\hline 21-Aug & 1:15 & Up & Yes & 70 & 408 \\
\hline 21-Aug & $1: 16$ & Down & Yes & $\sim$ & 407 \\
\hline 21-Aug & $2: 12$ & Up & Yes & 80 & 408 \\
\hline 21-Aug & $2: 14$ & Down & Yes & 80 & 407 \\
\hline 21-Aug & $2: 16$ & $\mathrm{Up}$ & Yes & 75 & 408 \\
\hline 21-Aug & $3: 25$ & Up & Yes & 70 & 409 \\
\hline 21-Aug & $3: 34$ & Down & Yes & 70 & 408 \\
\hline 21-Aug & 4:04 & Up & Yes & 70 & 409 \\
\hline 21-Aug & $5: 22$ & Down & Yes & 70 & 408 \\
\hline 21-Aug & $6: 16$ & Up & Yes & 70 & 409 \\
\hline 21-Aug & $7: 55$ & Down & Yes & 70 & 408 \\
\hline 21-Aug & $10: 17$ & Down & Yes & 80 & 407 \\
\hline 21-Aug & $16: 36$ & Up & Yes & 75 & 408 \\
\hline
\end{tabular}


Table A-1 (continued)

\begin{tabular}{|c|c|c|c|c|c|}
\hline $\begin{array}{l}\text { Date } \\
(2002)\end{array}$ & $\begin{array}{l}\text { Time } \\
\text { (hours) }\end{array}$ & $\begin{array}{r}\text { Direction } \\
\text { (up/down) }\end{array}$ & $\begin{array}{l}\text { Adipose Fin } \\
\text { (yes/no) }\end{array}$ & $\begin{array}{l}\text { Estimated } \\
\text { Length }(\mathrm{cm})\end{array}$ & $\begin{array}{c}\text { Net Upstream } \\
\text { Movement }\end{array}$ \\
\hline 21-Aug & $17: 47$ & Down & No & 80 & 407 \\
\hline 21-Aug & $17: 55$ & Up & Yes & 70 & 408 \\
\hline 21-Aug & 18:01 & Down & Yes & 70 & 407 \\
\hline 21-Aug & $18: 36$ & Down & Yes & 80 & 406 \\
\hline 21-Aug & $18: 45$ & Down & Yes & 80 & 405 \\
\hline 21-Aug & $18: 55$ & Up & Yes & 80 & 406 \\
\hline 21-Aug & $18: 56$ & Up & Yes & 80 & 407 \\
\hline 21-Aug & 19:09 & Down & Yes & 75 & 406 \\
\hline 21-Aug & $19: 48$ & Up & Yes & 75 & 407 \\
\hline 21-Aug & $19: 53$ & Down & Yes & 75 & 406 \\
\hline 21-Aug & $23: 38$ & Up & Yes & 70 & 407 \\
\hline 22-Aug & 1:36 & Down & Yes & 80 & 406 \\
\hline 22-Aug & $1: 51$ & Up & Yes & 80 & 407 \\
\hline 22-Aug & $5: 21$ & Down & Yes & 70 & 406 \\
\hline 22-Aug & $6: 25$ & Up & Yes & 70 & 407 \\
\hline 22-Aug & $6: 33$ & Down & Yes & 70 & 406 \\
\hline 22-Aug & $6: 34$ & Down & Yes & 70 & 405 \\
\hline 22-Aug & $9: 38$ & Up & Yes & 80 & 406 \\
\hline 22-Aug & $12: 13$ & Down & Yes & 75 & 405 \\
\hline 22-Aug & $12: 18$ & Down & Yes & 80 & 404 \\
\hline 22-Aug & $14: 17$ & Up & Yes & 80 & 405 \\
\hline 22-Aug & $16: 56$ & Down & Yes & 75 & 404 \\
\hline 22-Aug & $17: 09$ & Down & Yes & 75 & 403 \\
\hline 22-Aug & 20:09 & Down & No & 60 & 402 \\
\hline 22-Aug & $20: 10$ & Up & Yes & 80 & 403 \\
\hline 22-Aug & 20:10 & Up & No & 60 & 404 \\
\hline 22-Aug & $20: 13$ & Up & Yes & 75 & 405 \\
\hline 22-Aug & $20: 14$ & Down & Yes & 75 & 404 \\
\hline 22-Aug & $20: 17$ & Up & Yes & 75 & 405 \\
\hline 22-Aug & $20: 19$ & Down & Yes & 75 & 404 \\
\hline 22-Aug & $20: 23$ & Up & Yes & 75 & 405 \\
\hline 22-Aug & $20: 25$ & Down & Yes & 75 & 404 \\
\hline 23-Aug & $0: 28$ & Down & Yes & 70 & 403 \\
\hline 23-Aug & $0: 48$ & Up & Yes & 70 & 404 \\
\hline 23-Aug & $0: 54$ & Down & Yes & 70 & 403 \\
\hline 23-Aug & $1: 33$ & Up & Yes & 75 & 404 \\
\hline 23-Aug & $1: 46$ & Down & Yes & 70 & 403 \\
\hline 23-Aug & $1: 50$ & Up & Yes & 75 & 404 \\
\hline 23-Aug & $2: 03$ & Down & Yes & 70 & 403 \\
\hline 23-Aug & 2:04 & Up & Yes & 70 & 404 \\
\hline
\end{tabular}


Table A-1 (continued)

\begin{tabular}{|c|c|c|c|c|c|}
\hline $\begin{array}{l}\text { Date } \\
(2002)\end{array}$ & $\begin{array}{l}\text { Time } \\
\text { (hours) }\end{array}$ & $\begin{array}{r}\text { Direction } \\
\text { (up/down) }\end{array}$ & $\begin{array}{l}\text { Adipose Fin } \\
\text { (yes/no) }\end{array}$ & $\begin{array}{l}\text { Estimated } \\
\text { Length }(\mathrm{cm})\end{array}$ & $\begin{array}{c}\text { Net Upstream } \\
\text { Movement }\end{array}$ \\
\hline 23-Aug & 2:09 & Down & Yes & 70 & 403 \\
\hline 23-Aug & 4:03 & Up & No & 55 & 404 \\
\hline 23-Aug & $8: 38$ & Up & Yes & 80 & 405 \\
\hline 23-Aug & $8: 58$ & Down & Yes & 80 & 404 \\
\hline 23-Aug & 9:04 & Up & Yes & 80 & 405 \\
\hline 23-Aug & 9:07 & Down & Yes & 80 & 404 \\
\hline 23-Aug & $9: 14$ & Up & Yes & 80 & 405 \\
\hline 23-Aug & $9: 30$ & Down & Yes & 80 & 404 \\
\hline 23-Aug & $9: 30$ & Down & Yes & 70 & 403 \\
\hline 23-Aug & $14: 03$ & Down & Yes & 80 & 402 \\
\hline 23-Aug & $14: 30$ & Up & Yes & 80 & 403 \\
\hline 23-Aug & $15: 23$ & Up & Yes & 80 & 404 \\
\hline 23-Aug & $16: 23$ & Down & Yes & 70 & 403 \\
\hline 23-Aug & $19: 24$ & Down & Yes & 70 & 402 \\
\hline 23-Aug & $19: 58$ & Down & Yes & 80 & 401 \\
\hline 24-Aug & $0: 20$ & Up & Yes & 80 & 402 \\
\hline 24-Aug & 3:09 & Up & Yes & 80 & 403 \\
\hline 24-Aug & $4: 17$ & Down & Yes & 70 & 402 \\
\hline 24-Aug & $20: 48$ & Up & Yes & 55 & 403 \\
\hline 24-Aug & $21: 00$ & Down & Yes & 55 & 402 \\
\hline 24-Aug & $22: 25$ & Up & No & 85 & 403 \\
\hline 24-Aug & $23: 50$ & Down & Yes & 75 & 402 \\
\hline 25-Aug & $7: 50$ & Down & Yes & 90 & 401 \\
\hline 25-Aug & $23: 31$ & Down & Yes & 70 & 400 \\
\hline 26-Aug & \multicolumn{4}{|c|}{ Correction for outage $8 / 26,6: 24$ to $8 / 26,10: 24$ (0) } & 400 \\
\hline 27-Aug & $1: 31$ & Up & Yes & 75 & 401 \\
\hline 28-Aug & 2:01 & Down & Yes & 75 & 400 \\
\hline 28-Aug & 4:08 & Up & Yes & 70 & 401 \\
\hline 28-Aug & $16: 42$ & Down & No & 60 & 400 \\
\hline 28-Aug & $18: 29$ & Up & Yes & 80 & 401 \\
\hline 28-Aug & $18: 37$ & Up & Yes & 80 & 402 \\
\hline 28-Aug & $18: 37$ & Down & Yes & 80 & 401 \\
\hline 28-Aug & $18: 54$ & Down & Yes & 80 & 400 \\
\hline 28-Aug & 19:01 & Up & Yes & 80 & 401 \\
\hline 28-Aug & $19: 10$ & Up & No & 60 & 402 \\
\hline 29-Aug & $3: 53$ & Down & Yes & 80 & 401 \\
\hline 29-Aug & $6: 03$ & Down & No & 50 & 400 \\
\hline 29-Aug & $6: 30$ & Up & Yes & 80 & 401 \\
\hline 29-Aug & $7: 10$ & Down & Yes & $\sim$ & 400 \\
\hline 29-Aug & $12: 33$ & Down & Yes & 70 & 399 \\
\hline
\end{tabular}


Table A-1 (continued)

\begin{tabular}{rccccc}
\hline $\begin{array}{c}\text { Date } \\
\text { (2002) }\end{array}$ & $\begin{array}{c}\text { Time } \\
\text { (hours) }\end{array}$ & $\begin{array}{c}\text { Direction } \\
\text { (up/down) }\end{array}$ & $\begin{array}{c}\text { Adipose Fin } \\
\text { (yes/no) }\end{array}$ & $\begin{array}{c}\text { Estimated } \\
\text { Length }(\mathrm{cm})\end{array}$ & $\begin{array}{c}\text { Net Upstream } \\
\text { Movement }\end{array}$ \\
\hline 30-Aug & Correction for outage & 8/29, 13:46 to 8/30, 12:35 (-1) & 398 \\
31-Aug & $0: 00$ & 0 & 0 & 0 & 398 \\
1-Sep & $2: 31$ & Up & Yes & 70 & 399 \\
1-Sep & $4: 25$ & Down & Yes & 70 & 398 \\
1-Sep & $12: 04$ & Down & Yes & 75 & 397 \\
2-Sep & $16: 20$ & Down & Yes & 50 & 396 \\
3-Sep & $0: 00$ & 0 & 0 & 0 & 396 \\
4-Sep & $0: 00$ & 0 & 0 & 0 & 396 \\
5-Sep & $0: 00$ & 0 & 0 & 0 & 396 \\
6-Sep & $0: 00$ & 0 & 0 & 0 & 396 \\
7-Sep & $0: 00$ & 0 & 0 & 0 & 396 \\
8-Sep & $0: 00$ & 0 & 0 & 0 & 396 \\
9-Sep & $0: 00$ & 0 & 0 & 0 & 396 \\
10-Sep & $0: 00$ & 0 & 0 & 0 & 396 \\
11-Sep & $0: 00$ & 0 & 0 & 0 & \\
\hline
\end{tabular}


Table A-2. Diel movements of adult spring and summer chinook salmon passing through the Lake Creek fish counting station, by hour, in 2002.

\begin{tabular}{|c|c|c|c|c|}
\hline $\begin{array}{l}\text { Time } \\
\text { (hours }\end{array}$ & $\begin{array}{l}\text { Total Movements } \\
\text { (Up and Down) }\end{array}$ & $\begin{array}{l}\text { Percent }(\%) \text { Total } \\
\text { Movements }\end{array}$ & $\begin{array}{l}\text { Net Upstream } \\
\text { Movements }\end{array}$ & $\begin{array}{c}\text { Percent }(\%) \text { Net } \\
\text { Upstream Movements }\end{array}$ \\
\hline $0-1: 00$ & 32 & 8 & 63 & 7 \\
\hline $1-2: 00$ & 4 & 1 & 36 & 5 \\
\hline $2-3: 00$ & 11 & 3 & 43 & 6 \\
\hline $3-4: 00$ & 11 & 3 & 42 & 5 \\
\hline $4-5: 00$ & 7 & 2 & 33 & 4 \\
\hline $5-6: 00$ & 4 & 1 & 30 & 4 \\
\hline $6-7: 00$ & 25 & 6 & 46 & 5 \\
\hline $7-8: 00$ & 7 & 2 & 20 & 3 \\
\hline 8-9:00 & 2 & 1 & 17 & 2 \\
\hline 9-10:00 & 11 & 3 & 21 & 2 \\
\hline $10-11: 00$ & 18 & 5 & 23 & 2 \\
\hline $11-12: 00$ & 16 & 4 & 18 & 2 \\
\hline $12-13: 00$ & 18 & 5 & 26 & 3 \\
\hline $13-14: 00$ & 5 & 1 & 24 & 3 \\
\hline $14-15: 00$ & 13 & 3 & 31 & 4 \\
\hline $15-16: 00$ & 5 & 1 & 21 & 3 \\
\hline $16-17: 00$ & 39 & 10 & 65 & 7 \\
\hline $17-18: 00$ & 27 & 7 & 49 & 5 \\
\hline $18-19: 00$ & 23 & 6 & 42 & 5 \\
\hline $19-20: 00$ & 18 & 5 & 45 & 5 \\
\hline $20-21: 00$ & 31 & 8 & 43 & 4 \\
\hline $21-22: 00$ & 17 & 4 & 25 & 2 \\
\hline $22-23: 00$ & 23 & 6 & 41 & 4 \\
\hline $23-24: 00$ & 30 & 8 & 63 & 7 \\
\hline
\end{tabular}

Time - Military time (hours) 
Table A-3. Dates of net upstream migration and total movements of adult spring and summer chinook salmon through the Lake Creek fish counting station in 2002.

\begin{tabular}{|c|c|c|}
\hline Date & Net Upstream & Total Movements \\
\hline 11-Jun & 0 & 0 \\
\hline 12-Jun & 0 & 0 \\
\hline 13-Jun & 0 & 0 \\
\hline 14-Jun & 0 & 0 \\
\hline 15-Jun & 0 & 0 \\
\hline 16-Jun & 0 & 0 \\
\hline 17-Jun & 0 & 0 \\
\hline 18-Jun & 0 & 0 \\
\hline 19-Jun & 0 & 0 \\
\hline 20-Jun & 0 & 0 \\
\hline 21-Jun & 0 & 0 \\
\hline 22-Jun & 0 & 0 \\
\hline 23-Jun & 0 & 0 \\
\hline 24-Jun & 0 & 0 \\
\hline 25-Jun & 0 & 0 \\
\hline 26-Jun & 1 & 1 \\
\hline 27-Jun & 0 & 0 \\
\hline *28-Jun & 4 & 4 \\
\hline 29-Jun & 6 & 8 \\
\hline 30-Jun & 8 & 10 \\
\hline 1-Jul & 25 & 29 \\
\hline 2-Jul & 7 & 7 \\
\hline 3-Jul & 33 & 35 \\
\hline 4-Jul & 19 & 23 \\
\hline 5-Jul & 19 & 39 \\
\hline 6-Jul & 21 & 25 \\
\hline 7-Jul & 22 & 38 \\
\hline 8-Jul & 41 & 43 \\
\hline 9-Jul & 10 & 28 \\
\hline 10-Jul & 10 & 22 \\
\hline 11-Jul & 12 & 44 \\
\hline 12-Jul & 12 & 24 \\
\hline
\end{tabular}


Table A-3 (continued)

\begin{tabular}{|c|c|c|}
\hline Date & Net Upstream & Total Movements \\
\hline 13-Jul & 24 & 38 \\
\hline 14-Jul & 19 & 41 \\
\hline 15-Jul & 17 & 29 \\
\hline 16-Jul & 0 & 4 \\
\hline$* 17-\mathrm{Jul}$ & 1 & 5 \\
\hline 18-Jul & 5 & 5 \\
\hline 19-Jul & 4 & 12 \\
\hline 20-Jul & 0 & 4 \\
\hline 21-Jul & 1 & 1 \\
\hline 22-Jul & 3 & 3 \\
\hline 23-Jul & 1 & 17 \\
\hline 24-Jul & 3 & 3 \\
\hline 25-Jul & 0 & 10 \\
\hline 26-Jul & -2 & 20 \\
\hline 27-Jul & 5 & 5 \\
\hline 28-Jul & 5 & 7 \\
\hline 29-Jul & 1 & 5 \\
\hline 30-Jul & 2 & 10 \\
\hline 31-Jul & 1 & 17 \\
\hline 1-Aug & 1 & 7 \\
\hline 2-Aug & 5 & 25 \\
\hline 3-Aug & 4 & 10 \\
\hline 4-Aug & 5 & 5 \\
\hline 5-Aug & 0 & 36 \\
\hline 6-Aug & 1 & 33 \\
\hline 7-Aug & 1 & 35 \\
\hline 8-Aug & 6 & 20 \\
\hline 9-Aug & 9 & 15 \\
\hline 10-Aug & 11 & 45 \\
\hline 11-Aug & 5 & 23 \\
\hline 12-Aug & 5 & 21 \\
\hline 13-Aug & 1 & 51 \\
\hline 14-Aug & 2 & 42 \\
\hline
\end{tabular}


Table A-3 (continued)

\begin{tabular}{|c|c|c|}
\hline Date & Net Upstream & Total Movements \\
\hline 15-Aug & 5 & 45 \\
\hline 16-Aug & -3 & 51 \\
\hline 17-Aug & 0 & 38 \\
\hline 18-Aug & 9 & 57 \\
\hline 19-Aug & -1 & 37 \\
\hline 20-Aug & 1 & 29 \\
\hline 21-Aug & 0 & 24 \\
\hline 22-Aug & -3 & 21 \\
\hline 23-Aug & -3 & 23 \\
\hline 24-Aug & 1 & 7 \\
\hline 25-Aug & -2 & 2 \\
\hline *26-Aug & 0 & 0 \\
\hline 27-Aug & 1 & 1 \\
\hline 28-Aug & 1 & 9 \\
\hline *29-Aug & -3 & 5 \\
\hline *30-Aug & 0 & 0 \\
\hline 31-Aug & 0 & 0 \\
\hline 1-Sep & -1 & 3 \\
\hline 2-Sep & -1 & 1 \\
\hline 3-Sep & 0 & 0 \\
\hline 4-Sep & 0 & 0 \\
\hline 5-Sep & 0 & 0 \\
\hline 6-Sep & 0 & 0 \\
\hline 7-Sep & 0 & 0 \\
\hline 8-Sep & 0 & 0 \\
\hline 9-Sep & 0 & 0 \\
\hline 10-Sep & 0 & 0 \\
\hline \multirow[t]{2}{*}{ 11-Sep } & 0 & 0 \\
\hline & Operation & Ceased \\
\hline
\end{tabular}

*Includes estimate during equipment outage 
Table A-4. Corrections for turbidity and equipment downtime at the Lake Creek fish counting station, 2002.

\begin{tabular}{cccccc}
\hline & $\begin{array}{r}\text { Downtime } \\
\text { Date/Time Outage }\end{array}$ & $\begin{array}{r}\text { Correction } \\
\text { (Hours:Minutes) } \\
\text { (No. of Fish) }\end{array}$ & $\begin{array}{c}\text { 95\% } \\
\text { Confidence Interval }\end{array}$ & $\begin{array}{c}\text { Standard } \\
\text { Deviation }\end{array}$ & Variance \\
\hline 6/24-15:11 to 6/24-22:25 & $7: 14$ & +0.00 & \pm 0.00 & 0.0000 & 0.0000 \\
6/28-13:27 to 6/28-14:49 & $1: 22$ & +0.00 & \pm 0.00 & 0.0000 & 0.0000 \\
7/717-4:47 to 7/17-13:47 & $9: 00$ & +3.00 & \pm 02.27 & 07559 & 0.5714 \\
8/26-6:24 to 8/26-10:24 & $4: 00$ & -0.20 & \pm 0.40 & 0.2236 & 0.0500 \\
$8 / 29-13: 46$ to 8/30-12:35 & $22: 50$ & -0.75 & \pm 1.80 & 0.3765 & 0.1418 \\
Total & $44: 26$ & 2.05 & \pm 4.47 & & 0.7632 \\
\hline
\end{tabular}

